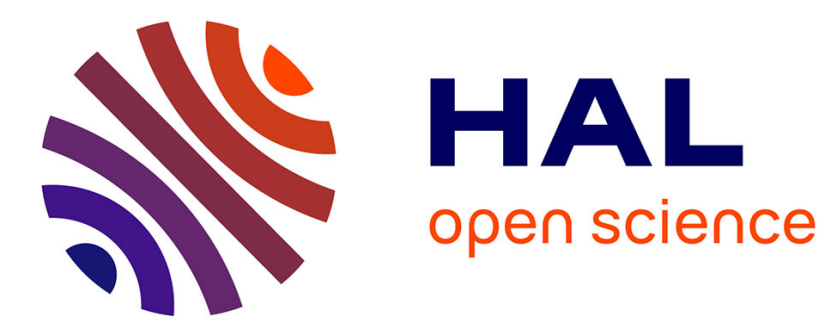

\title{
Excess Control Rights, Financial Crisis and Bank Profitability and Risk
}

\author{
Amine Tarazi, Nadia Zedek
}

\section{To cite this version:}

Amine Tarazi, Nadia Zedek. Excess Control Rights, Financial Crisis and Bank Profitability and Risk. 2013. hal-00916550

\section{HAL Id: hal-00916550 \\ https://hal-unilim.archives-ouvertes.fr/hal-00916550}

Preprint submitted on 10 Dec 2013

HAL is a multi-disciplinary open access archive for the deposit and dissemination of scientific research documents, whether they are published or not. The documents may come from teaching and research institutions in France or abroad, or from public or private research centers.
L'archive ouverte pluridisciplinaire HAL, est destinée au dépôt et à la diffusion de documents scientifiques de niveau recherche, publiés ou non, émanant des établissements d'enseignement et de recherche français ou étrangers, des laboratoires publics ou privés. 


\title{
Excess control rights, financial crisis and bank profitability and risk
}

\author{
Amine Tarazi ${ }^{\mathrm{a}}$, Nadia Zedek ${ }^{\mathrm{a}}$ \\ ${ }^{a}$ Université de Limoges, LAPE, 5 rue Félix Eboué, 87031 Limoges Cedex, France
}

\begin{abstract}
We empirically investigate the impact of shareholders' excess control rights (greater control than cash-flow rights) on bank profitability and risk before, during, and after the global financial crisis of 2007-2008. We use a unique hand-crafted dataset tracing the complete control chains of 788 European commercial banks and cover the 2002-2010 period. We find that the presence of excess control rights is associated with lower profitability, higher risktaking and higher default risk before (2002-2006) and after (2009-2010) the crisis. Conversely, it improves profitability and no longer affects risk during the crisis (2007-2008). Further evidence shows that, regardless of the period, the effect of excess control rights on profitability and risk is accentuated in family-controlled banks and in countries with relatively weak shareholder protection rights and that such an effect is only effective at intermediate and high levels of excess control rights. Overall, our findings contribute to the literature examining the corporate governance determinants of banks' performance during the 20072008 financial crisis and have several policy implications.
\end{abstract}

JEL Classification: G21, G28

Keywords: European banking, excess control rights, pyramids, financial crisis, profitability, risk

\footnotetext{
† Corresponding author: nadia.zedek@ unilim.fr (N. Zedek), Tel: + 33555149251.
} 


\section{Introduction}

Weak corporate governance in the banking industry has often been considered as one of the causes of the global financial crisis of 2007-2008. As such, the Basel Committee on Banking Supervision (BIS, 2010a) has called for better governance mechanisms within financial institutions. Although a large number of banks failed or were rescued during the crisis, some banks performed worse than others. Various papers have investigated the factors behind such cross-variation in bank performance and some works (e.g., Gropp and Köhler, 2010; Fahlenbrach and Stulz, 2011; Aebi et al., 2012; Beltratti and Stulz, 2012; Berger et al., 2012; Erkens et al., 2012) have specifically examined the role played by corporate governance (e.g., manager compensation schemes, board structure, ownership concentration). In this paper, we investigate whether the presence of controlling shareholders with greater control rights than cash-flow rights in pyramidal ownership structures -who play a major role in the European banking industry- affects bank profitability and risk differently during normal times and distress times.

The corporate governance literature argues that the presence of controlling shareholders can be either good or bad for minority shareholders and the firm's performance. On the positive side (incentives view), the presence of controlling shareholders mitigates the standard ownermanager agency problem (Jensen and Meckling, 1976) because of their ability and incentives to monitor managers (Shleifer and Vishny, 1986; 1997). On the negative side (entrenchment view), controlling shareholders may pursue their own interests and distort management decision-making leading to insider expropriation (Shleifer and Vishny, 1997). ${ }^{1}$ In the extant literature (e.g., Claessens et al., 2002; Boubakri and Ghouma, 2010; Lin et al., 2011), the likelihood of expropriation and tunneling is generally measured by the divergence between control or voting rights (the right to vote and therefore to control) and cash-flow rights (the right to receive dividends) in pyramids, namely referred to as excess control rights.

While the divergence between control and cash-flow rights is found to negatively impact firm value and performance in general (Claessens et al., 2002) and bank profitability more specifically (Azofra and Santamaría, 2011), ${ }^{2}$ how it affects shareholder behavior and

\footnotetext{
${ }^{1}$ Expropriation can take several forms. For example, entrenched controlling shareholders can tunnel (divert) resources from a firm where they have lower financial interests to another firm where they hold substantial financial interests (e.g., Bertrand et al., 2002; La Porta et al., 2003; Baek et al., 2004). Tunneling behavior can take several forms and mainly the form of related-lending (Laeven, 2001; La Porta et al., 2003; Beck et al., 2003).

${ }^{2}$ Azofra and Santamaría (2011) study Spanish commercial banks during the 1996-2004 sound period and find that a divergence between control and cash-flow rights negatively impacts their profitability.
} 
profitability but also risk-taking and default risk during times of distress remains an open question. On the one hand, firms controlled by entrenched shareholders could suffer from sharper declines in profitability during bad times. Consistent with the expropriation view (Johnson et al., 2000; Mitton, 2002; Baek et al., 2004), entrenched controlling shareholders might have even stronger incentives to divert resources for their own benefits during bad times to compensate the losses (or lower returns) they might be enduring in their other firms. Moreover, while investors and market participants might pay less attention to weak governance when the economy is doing well, they are likely to take it more into consideration during a crisis and might pull out from the firm leading to poorer performance (Rajan and Zingales, 1998). On the other hand, according to the propping up view (Friedman et al., 2003), firms controlled by entrenched shareholders might endure lower declines in profitability if they benefit from private funds from their shareholders who are keen on redistributing resources among all the entities they control (pyramidal ownership structure) to prevent all the firms from financial distress. From the profit-sharing view (among all the controlled firms), keeping the firm in business is important because it increases the expectations of future expropriation opportunities (e.g., providing support for connectedfirms). In any case, propping up behavior makes firms suffer less during a crisis period (Friedman et al., 2003).

The financial crisis of 2007-2008 provides a natural experiment that allows us to investigate the effect of excess control rights on bank performance (profitability and risk) during sound and distress periods. Investigating such a relationship across crisis and sound periods for banks is of particular interest because such behaviors (expropriation or propping up) might be exacerbated or attenuated in the banking industry given its unique features. During a sound period, expropriation might be easier in banks because they are considered as more opaque than other firms and their assets are more complex (Morgan, 2002). For instance, entrenched controlling shareholders can push banks to lend at favorable conditions to other related-firms where they have considerable financial interests (La Porta et al., 2003). During a distress period, expropriation might more likely occur than propping up because banks benefit from safety nets and public support (deposit insurance, bail-out policies and government intervention). Furthermore, during downturns, banks generally reduce their lending (e.g, Ivashina and Scharfstein, 2010) but might extend it (or reduce it but to a lesser extent) to their shareholders' related-firms than to other firms to support them. However, during a financial crisis, more stringent regulatory oversight and stronger market discipline might also mitigate entrenchment and opportunistic behavior more strongly in banks than other firms. Also, 
bankruptcy costs could be higher for banks related to other firms within a pyramid. If such banks fail, related-firms would need to borrow from other banks at possibly less favorable conditions increasing the overall cost of funding for the pyramid. Hence, just like nonfinancial firms, banks controlled by entrenched shareholders in pyramids might also benefit from the support of related-firms (propping up behavior) but such a support might even be more pronounced for banks than for non-financial firms. Consequently, banks controlled by shareholders with excess control rights might possibly outperform other banks during a crisis.

Specifically, in this paper we use a unique hand-crafted sample with detailed ownership information on 788 commercial banks based in 17 Western European countries ${ }^{3}$ over 20022010 which covers the pre-crisis (2002-2006), the crisis (2007-2008) and the post-crisis (2009-2010) periods to explore the effect of excess control rights on bank profitability and risk over the three periods.

We control for various factors and, in line with the entrenchment view, find excess control rights to be negatively associated with bank profitability and positively linked with risk-taking and default risk before the crisis. However, during the 2007-2008 financial crisis, consistent with the propping up view, the impact of excess control rights on profitability becomes positive and it is no longer significant regarding risk-taking and default risk. Nevertheless, such a reversed impact is short-lived because after the crisis (2009-2010), excess control rights are again negatively linked with profitability and positively with default risk.

We go further in our investigation by considering the factors that might influence the relationship between excess control rights and bank profitability and risk. Specifically, we consider the effect of family ownership and the level of shareholder protection rights since the incentives and the likelihood of expropriation are known to be higher in family-controlled firms (Claessens et al., 2002; Villalonga and Amit, 2006) and in countries with weak shareholder protection rights (La Porta et al., 2002; Dyck and Zingales, 2004). Consistent with such predictions, we find that, regardless of the state of the economy, the effect of excess control rights on profitability and risk is stronger in family-controlled banks and in shareholder less protective countries. Particularly, family-controlled banks and banks located in countries with weak shareholder protection which are found to have poorer performance (lower profitability and higher risk-taking and default risk) before the crisis are also the ones with higher profitability and lower earnings volatility during the crisis. We also investigate

\footnotetext{
${ }^{3}$ We focus on European countries where the presence of excess control rights is more acute compared to other countries, for instance, the U.S. (La Porta et al., 1998).
} 
the effect of excess control rights on the changes in individual and industry-adjusted bank profitability. We find that, during the crisis, excess control rights contribute to improve the performance of banks compared to their past performance but also to their past performance relatively to their peers. For deeper insights, we further examine whether the shareholder's entrenchment behavior depends on the extent of excess control rights since the relationship between ownership and firm performance is known to be nonlinear (Morck et al., 1988; Adams and Santos, 2006). Consistent with this conjecture, we find that, irrespective of the state of the economy, the effect of excess control rights on bank performance is essentially effective at intermediate and high levels of excess control rights.

This paper extends the literature in several directions. First, our study focuses on whether bank profitability and risk are impacted by shareholders' excess control rights during distress periods. Unlike studies on nonfinancial firms (Johnson et al., 2000; Mitton, 2002; Baek et al., 2004; Bae et al., 2012), we find banks controlled by shareholders with excess control rights to be more resilient to shocks. Also, this paper adds to the growing body of literature which investigates whether the cross-variation in banks' performance during the 2007-2008 financial crisis can be explained by corporate governance mechanisms (Gropp and Köhler, 2010; Fahlenbrach and Stulz, 2011; Aebi et al., 2012; Beltratti and Stulz, 2012; Berger et al., 2012; Erkens et al., 2012). While these studies have mainly focused on owner-manager conflicts of interest (Jensen and Meckling, 1976), in our work we consider the conflicts between controlling and minority shareholders in complex pyramidal ownership structures (La Porta et al., 1998) and find that ownership structure and control do matter in explaining crossvariation in profitability and risk. In our work, we concomitantly consider the pre-crisis, crisis and post-crisis periods and shed light on whether a different influence of excess control rights on profitability and risk during the crisis is more or less persistent. Second, instead of investigating the impact of the divergence between control and cash-flow rights on profitability per se (as in Azofra and Santamaría, 2011 who study Spanish banks before the crisis), we also consider implications on bank risk-taking and stability. Moreover, we go beyond by looking at the type of controlling owners (e.g., family, state, firm, bank, institutional investors) and account for the level of shareholder protection in different European countries. Finally, unlike studies on pyramidal ownership structure (see, e.g., La Porta et al., 1999; Claessens et al., 2000; Faccio and Lang, 2002 for nonfinancial firms and Caprio et al., 2007; Laeven and Levine, 2009 for banking firms) which mainly consider the largest publicly traded corporations at a given point in time, we collect a larger database including large and small banks, both publicly traded and privately owned and account for 
changes in ownership structure through time. ${ }^{4}$ Our results are consistent with the concerns of the Basel Committee on Banking Supervision (BIS, 2010a) regarding corporate governance within complex ownership structures and recommending further disclosure of banking entities' ownership.

The rest of the paper is structured as follows. In Section 2, we describe the data and the empirical method. Section 3 presents the sample characteristics and some univariate analysis. In Section 4, we discuss the econometric results. Section 5 reports the robustness checks and Section 6 concludes the paper.

\section{Data and method}

In this section, before presenting the empirical approach and our set of variables, we describe our sample.

\subsection{Sample}

Our study focuses on commercial banks based in 17 Western European countries (Austria, Belgium, Denmark, Finland, France, Germany, Greece, Ireland, Italy, Luxembourg, the Netherlands, Norway, Portugal, Spain, Sweden, Switzerland and the United Kingdom) during the 2002-2010 period which covers the pre-crisis (2002-2006), the crisis (2007-2008) and the recovery (2009-2010) periods. ${ }^{5}$ Bank level accounting data are retrieved from BvD BankScope. For each bank, we use unconsolidated data if available; otherwise we use consolidated statements. ${ }^{6}$ To collect ownership information of the sampled banks, we use BankScope and Amadeus databases -as primary sources- together with annual reports. We also use World Bank Database to collect country-level and macroeconomic variables. For the time period and countries covered by this study, we identify 952 commercial banks for which we have detailed information on ownership structure and at least three subsequent years of time series observations. ${ }^{7}$ To minimize the effect of outliers, we remove 164 banks by eliminating extreme observations (2.5\% lowest and highest values) for each financial variable of interest. We hence end up with a final sample of 4,451 bank-year observations

\footnotetext{
${ }^{4}$ Azofra and Santamaría (2011) also consider publicly traded and privately owned banks in their database and account for the time dimension of ownership structure but they focus on a single country (Spain) before the crisis period (1996-2004). In their work, they look at bank profitability but not at bank risk-taking and bank solvency.

${ }^{5}$ We follow the definition provided by the Bank of International Settlements (BIS, 2010b) and define the 2-year window 2007-2008 as the acute crisis years and the 2009-2010 as our post-crisis/recovery period.

${ }^{6}$ Our empirical analysis relies to a large extent on unconsolidated bank statements. In some cases, BankScope provides information only for consolidated data. We check the robustness of our results using unconsolidated data solely.

${ }^{7}$ This criterion enables us to compute rolling-window means and standard deviations of our performance indicators (profitability and risk).
} 
corresponding to 788 commercial banks, 132 of which are listed. Table 1 reports a breakdown of the sample by country and shows its representativeness by comparing the aggregate total assets of the sample banks in a given country with the aggregate assets of all the banks covered by BankScope in the same country. On average, the final sample covers, as a whole, more than $79 \%$ of total bank assets in the considered countries and at least $40 \%$ of total bank assets in each country.

[Insert Table 1 about here]

\subsection{Method and variables}

We aim to investigate the effect of excess control rights on bank profitability and risk and more specifically how this effect differs according to the state of the economy. A crisis (shock) might affect the behavior of entrenched controlling shareholders more or less persistently. We therefore consider the pre-crisis and crisis periods but also the post-crisis (recovery) period. To capture differences in the effect of excess control rights on bank performance (profitability and risk) across these periods, we introduce two time binary variables which we group in the vector TDummy: a crisis dummy (Crisis) and a post-crisis dummy (PostCrisis) and we consider their interactions with the excess control rights variable (ExcessControl). The variables Crisis and PostCrisis take the value of one in 2007-2008 and 2009-2010 respectively, and zero otherwise. We therefore estimate the following panel regression with bank-specific $(\mathrm{X})$ and country-specific $(\mathrm{Z})$ control variables:

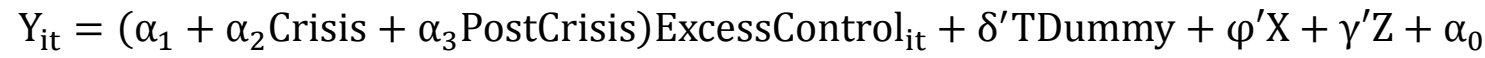

$$
\begin{aligned}
& +\varepsilon_{\mathrm{it}},
\end{aligned}
$$

where $Y_{i t}$ is a measure of profitability or risk for bank $\mathrm{i}$ in year $\mathrm{t}$; ExcessControl corresponds to excess control rights which is the difference between control and cash-flow rights; $\varepsilon_{i t}$ is the error term.

The parameters $\alpha_{1}, \alpha_{1}+\alpha_{2}$ and $\alpha_{1}+\alpha_{3}$ measure the effect of the shareholder's excess control rights (ExcessControl) on bank profitability and risk during the pre-crisis (20022006), the crisis (2007-2008) and the post-crisis (2009-2010) periods respectively.

We now turn to the definitions of our dependent variable reflecting bank performance (profitability and risk), our ownership variable of interest (excess control rights) and the different control variables introduced in our regressions. The definition and descriptive statistics of all the variables used in our regressions are provided in Table 2. 


\subsubsection{Profitability, risk and default risk measures}

We measure profitability for each bank by computing the 3-year (from t-2 to t) rollingwindow mean of the return on average assets ${ }^{8}$ defined as the ratio of net income to average total assets (ROA). ${ }^{9}$

We consider different measures of risk-taking and default risk which are all computed on the basis of 3-year rolling-window (from t-2 to $t$ ) using annual accounting data throughout the 2002-2010 period. As a measure of bank risk-taking, we compute the 3-year rolling-window standard deviation of the return on average assets (SDROA). A higher standard deviation of the return on average assets indicates higher risk-taking. We also consider a proxy of default risk for each bank. We compute the Z-score (ZScore) as proposed by Boyd and Graham (1986). Lower values of ZScore indicate a higher probability of failure. For deeper insights, we also split ZScore into its two additive components Z1Score and Z2Score as in Goyeau and Tarazi (1992) and Lepetit et al. (2008). Z1Score is a measure of asset risk and Z2Score is a measure of leverage risk. ${ }^{10}$ Considering these two components allows us to capture the extent to which a change in default risk (ZScore) is driven by a change in leverage and/or in asset risk.

\subsubsection{Measuring excess control rights}

Our variable of interest is excess control rights which we define as the difference between control and cash-flow rights (ExcessControl). We obtain information on control and cashflow rights by tracing a complete control chain in a pyramidal structure at the control threshold $^{11}$ of $10 \%$ for the years 2004 and $2006 .{ }^{12}$ To build these control chains, we first identify all the shareholders holding at least $10 \%$ of the shares of each bank by collecting data on direct ownership from BankScope (for the years 2004 and 2006) and complete it with information from annual reports. If the bank has at least one shareholder with $10 \%$ or more of

\footnotetext{
${ }^{8}$ We compute average assets at time $t$ as: (total assets at time $t+$ total assets at time $\left.t-1\right) / 2$.

${ }^{9}$ We use the return on average assets (ROA) rather than the return on equity (ROE) because we are more concerned by banks' effectiveness in efficiently managing their assets in good and bad times than by their leverage (capital) which is severely impacted during a crisis.

${ }^{10}$ ZScore $=$ Z1Score + Z2Score $=\frac{\text { ROA }}{\text { SDROA }}+\frac{\text { equity/assets }}{\text { SDROA }}$, where equity/assets at time $\mathrm{t}$ is the 3-year rollingwindow mean of the ratio of total equity to total assets.

${ }^{11}$ To build the control chains, we need to set a threshold (minimum percentage of shares held) to identify each owner inside the control chain. We follow previous studies on both banking firms (Caprio et al., 2007; Laeven and Levine, 2009) and nonfinancial firms (La Porta et al., 1999; Laeven and Levine, 2008) and we use a control threshold of $10 \%$ assuming that it provides a significant fraction of votes for effective control. As a robustness check, we also consider a $20 \%$ threshold.

${ }^{12}$ We collect the data only for two years of the pre-crisis period because ownership structure is known to be relatively stable over time (La Porta et al., 1999; Laeven and Levine, 2009). Before 2004, Bankscope and Amadeus do not report information on the type of the shareholder (e.g., firm, bank, institutional investors).
} 
total outstanding shares, we classify it as controlled; otherwise, it is classified as widely held. If some of these identified shareholders are not controlled by another shareholder (such as a family or a state), we consider them to be the ultimate controlling owners. If, however, some or all of these shareholders are themselves financial or nonfinancial corporations, we continue the process and build indirect control chains by identifying their owners, the owners of their owners until we reach ultimate shareholders. ${ }^{13}$ Since BankScope reports ownership information only for banks, we use the Amadeus database and annual reports (still considering data from 2004 and 2006) to gather ownership data on nonbanking firms that are shareholders at the intermediate levels of indirect control chains.

Given the built control chain for each bank, we compute control rights, cash-flow rights and excess control rights using the method initially proposed by La Porta et al. (1999). We define the aggregate control rights (ControlRights) as the sum of direct and indirect control rights. Direct control rights are measured by the ultimate controlling shareholder's stake directly held in the bank. Following La Porta et al. (1999), we define indirect control rights as the stake held in the first layer of the control chain. For example, if an entity A owns fraction $\mathrm{c}$ of corporation $\mathrm{C}$, and this corporation $\mathrm{C}$ in turn owns fraction $\mathrm{b}$ of bank $\mathrm{B}$, and both $\mathrm{b}$ and $\mathrm{c}$ are greater than the pre-defined $10 \%$ threshold, then the entity A's indirect control rights in bank $\mathrm{B}$ are equal to $\mathrm{b}$. If in addition to this indirect stake entity $\mathrm{A}$ owns a direct fraction $\mathrm{d}$ in bank $\mathrm{B}$, then direct control rights are equal to $\mathrm{d}$ and the aggregate control rights are the sum of both stakes $(d+b)$. Similarly, we measure the aggregate cash-flow rights (Cash-flowRights) of the ultimate controlling shareholder as the sum of direct and indirect cash-flow rights. Direct cash-flow rights are defined as direct ownership stakes held by the ultimate controlling shareholder in the bank. We define indirect cash-flow rights as the product of the ownership stakes held indirectly along the control chain. In the previous example, direct and indirect cash-flow rights of entity $\mathrm{A}$ in bank $\mathrm{B}$ are respectively equal to $\mathrm{d}$ and the product of $\mathrm{b}$ and $\mathrm{c}$ and its aggregate cash-flow rights are the sum of its direct $(d)$ and indirect $(b \times c)$ stakes. When a bank is controlled by multiple ultimate owners, we define the ultimate controlling shareholder as the owner with the greatest control rights. ${ }^{14}$ When the bank is widely-held (there is no shareholder with at least $10 \%$ of control rights), we set aggregate control and cash-flow rights equal to zero. We finally define excess control rights as the difference

\footnotetext{
${ }^{13}$ Horizontally, the number of different ultimate controlling owners for a given bank in our sample reaches a maximum of nine. Vertically, the maximum number of intermediate levels required to build the indirect control chain until the ultimate owner is eight.

${ }^{14}$ Over the 2002-2006 period, among the set of controlled banks in our sample, 525 are continuously classified as controlled by a single ultimate owner and 154 are continuously classified as controlled by multiple ultimate owners while 44 banks switch from one category to the other.
} 
between control and cash-flow rights (ExcessControl=ControlRights-Cash-flowRights) as in La Porta et al. (1999).

\subsubsection{Control variables}

We include in our estimations a large set of control variables which are expected to affect bank profitability and risk. These variables capture individual bank characteristics (X) and also macroeconomic as well as institutional and regulatory factors at the country level (Z).

\subsubsection{Bank specific control variables}

We include the natural logarithm of bank total assets to account for bank size (Log(Assets)). The expected sign for the relationship between bank size and bank profitability is not clearcut. Larger banks may have higher profitability because they benefit from scale and scope economies and from higher market power (McAllister and McManus, 1993; Pasiouras and Kosmidou, 2007). However, larger banks may be less profitable than small banks because they are more complex and face higher agency costs (Berger et al., 1987). Similarly, the relationship between bank size and risk is also ambiguous. On the one hand, larger banks have greater ability to diversify their risk and should have more stable earnings and hence lower default risk (Demsetz and Strahan, 1997). On the other hand, because of the presence of too-big-to-fail policies, larger banks might have higher incentives to take more risk (Galloway et al., 1997). The second control variable we include is the ratio of equity to total assets (Equity). ${ }^{15}$ The effect of bank capitalization on profitability is expected to be positive because better capitalized banks are able to raise funds at a lower cost (Bourke, 1989; Berger, 1995; Iannotta et al., 2007). While the effect of bank capitalization on default risk is expected to be negative, its effect on risk-taking is not clear. Banks with higher capital ratios are safer and take less risk (Keeley, 1990) but higher capital ratios due to more stringent capital regulation can encourage banks to take on more risk to maintain the expected return to shareholders (Koehn and Santomero, 1980; Kim and Santomero, 1988). In such a case, a positive link would be expected between the ratio of equity to total assets and risk-taking (Iannotta, 2006; Barry et al., 2011). We also introduce the ratio of deposits to total assets (Deposits). While banks with higher deposits-to-assets ratio are expected to be more risky (Iannotta et al., 2007), the impact on profitability is uncertain. Banks with larger deposit base might be more

\footnotetext{
${ }^{15}$ Table A1 in the Appendix shows the correlation coefficients among the key explanatory variables used in our regressions. On the whole, the correlation coefficients are low except for bank size as measured by the natural logarithm of total assets ( $\log ($ Assets)) and the ratio of equity to total assets (Equity). We hence orthogonalize Equity with respect to $\log$ (Assets).
} 
profitable because such funds are cheaper especially in the presence of deposit insurance (Iannotta et al., 2007; Gropp and Köhler, 2010). However, deposits are also costly in terms of fixed and labor costs (branching) possibly leading to lower profitability (Barry et al., 2011). We also include the ratio of total loans to total assets (Loans). A higher loans-to-assets ratio might lead to higher profitability if loans are more profitable than other assets ( Iannotta et al., 2007). However, profitability can be lower because loans are more costly to produce than other assets and some of them become non-performing (Bourke, 1989; Molyneux and Thornton, 1992). Therefore, the overall effect depends on which effect dominates. Regarding risk, the impact is expected to be negative. Loans are usually more stable than non-traditional intermediation activities and contribute to lower earnings volatility and default risk (Iannotta et al., 2007). We control for differences in business models by including the ratio of net noninterest income to net operating income (NNII). Income from non-traditional activities is expected to have a positive effect on profitability and risk. Overall, previous studies find that greater reliance on non-interest income activities is associated with higher risk and lower riskadjusted profitability (Stiroh, 2004; Lepetit et al., 2008). To account for operational efficiency, we use the cost-to-income ratio (CostIncomeRatio) which we expect to have a negative effect on bank profitability and a positive effect on risk (Athanasoglou et al., 2008; Shehzad et al., 2010; Barry et al., 2011). We also include a dummy variable Listed to control for the public or private status of the bank. Publicly listed banks are expected to be more profitable but also more risky (Iannotta et al., 2007; Shehzad et al., 2010; Barry et al., 2011). During the 2007-2008 financial crisis, some of the banks in our sample benefitted from public support. To control for the influence of government interventions, and specifically capital injections, on profitability and risk we include a dummy variable Rescue which takes the value of one if the bank was rescued during the crisis, and zero otherwise (Petrovic and Tutsch 2009). Finally, we control for differences in ownership type (Barry et al., 2011) by including a set of dummy variables which reflect the type of the largest ultimate controlling shareholder: Bank, Family, State, Institutional, Industry and Foundation which respectively take the value of one if the largest ultimate controlling owner is a bank; an individual, a family or a manager; ${ }^{16}$ a state or a public authority; a financial company, an insurance company, a mutual or a pension fund; an industrial firm; and a foundation or a research

\footnotetext{
16 Note that following La Porta et al. (1999), we classify a bank as family-controlled if the controlling shareholder is a person. We hence include inside this category banks controlled by an individual, a family or a manager.
} 
institute. $^{17}$

\subsubsection{Country specific variables}

We include the growth rate of the real gross domestic product (GDPGrowth) to control for differences in the macroeconomic environment. We expect a higher growth rate of GDP to be associated with higher profitability (Molyneux and Thornton, 1992; Iannotta et al., 2007; Albertazzi and Gambacorta, 2009) and lower risk (Beltratti and Stulz, 2012; Distinguin et al., 2013). To capture the institutional environment, we use the index of shareholder protection (RightsProtection) as defined by Djankov et al. (2008). Higher values of the index indicate better protection of minority shareholders. Higher values of the index should be associated with higher profitability because in countries with strong shareholder protection, the interests of insiders (managers/controlling shareholders) are better aligned with those of minority shareholders who should less suffer from expropriation (Gropp and Köhler, 2010). Concomitantly, if the alignment hypothesis is not rejected, shareholders might push managers to take higher risk (Laeven and Levine, 2009; Gropp and Köhler, 2010). We hence expect banks located in countries with strong shareholder protection to be more risky. To control for the regulatory environment, we include two indexes: CapitalStringency and OfficialSupervisory. ${ }^{18}$ While CapitalStringency measures regulatory oversight on bank capital, OfficialSupervisory reflects the degree of supervisory authority power. Higher values of both indexes indicate respectively stronger regulatory oversight on capital and a more powerful supervisory authority. The effect of these regulatory variables on bank profitability and risk is ambiguous. Stronger capital oversight and the presence of a powerful supervisory authority should reduce risk-taking and enhance bank stability (Beltratti and Stulz, 2012). As a consequence, expected profitability should be lower. However, in countries with stronger capital oversight and a powerful supervisory authority, banks may also take higher risk to compensate for the loss in utility (Laeven and Levine, 2009). In that case, these variables should be positively associated with both profitability and risk.

\section{Sample characteristics and univariate analysis}

In this section, we first present the broad characteristics of our sample of European banks. Then, using univariate mean tests we investigate the relationship between excess control rights and bank profitability and risk throughout the pre-crisis, the crisis and the post-crisis

\footnotetext{
${ }^{17}$ Note that the benchmark group is the category of widely-held banks (Widely).

${ }^{18}$ Details on the source and the definition of these indexes are provided in Table 2.
} 
periods.

\subsection{Ultimate ownership characteristics in Western Europe}

Over the pre-crisis period (2002-2006), our dataset indicates ${ }^{19}$ that around $87 \%$ of the observations relate to banks controlled by at least one ultimate shareholder. Amongst banks that are controlled, $57 \%$ of the observations refer to an ultimate shareholder with equal control and cash-flow rights and $43 \%$ to an ultimate shareholder with excess control rights.

To better emphasize the ownership characteristics of the sample banks, we further analyze the ownership type depending on (i) the presence and the absence of excess control rights and (ii) the level of shareholder protection rights. We hence divide the sampled banks into two groups based on the median value of the excess control rights variable: banks without excess control rights (ExcessControl=0) and banks with excess control rights $($ ExcessControl $>0){ }^{20}$ We again split each subsample of banks (with and without excess control rights) with respect to the median value of the shareholder protection index ${ }^{21}$ into countries with above-median (strong rights) and below-median (weak rights) shareholder protection rights. In panel A of Table 3, for each subsample of banks with and without excess control rights we report information on the proportion of each largest shareholder category. In panel B of Table 3, we report the same information with respect to the level of shareholder protection (strong versus weak rights).

Considering panel A, the data show that, while in the absence of excess control rights the largest ultimate controlling owner is essentially (34.41\% of the observations) another bank (Bank), banks are more rarely controlling owners with excess control rights (only $19.03 \%$ of the observations). Families (Family) and states (State) are predominantly controlling shareholders with excess control rights (respectively $34.20 \%$ and $16.89 \%$ of the observations) but they are less present in banks without excess control rights (respectively $19.86 \%$ and $4.12 \%$ of the observations). Institutional investors (Institutional) and industrial companies (Industry) are almost equally distributed across the two subsamples; they respectively

\footnotetext{
${ }^{19}$ Note that the sample characteristics provided in this paragraph are not tabulated.

${ }^{20} \mathrm{~A}$ bank is classified as without excess control rights if it is controlled by an ultimate owner with equal control and cash-flow rights or if it is widely-held. A bank is classified as with excess control rights if it is controlled by an ultimate owner with greater control than cash-flow rights. The classification of banks as without or with excess control rights changes over time. Amongst the 788 banks in our sample, 430 are continuously categorized as without excess control rights and 288 as with excess control rights while 70 banks switch from one category to the other over the pre-crisis period.

${ }^{21}$ In our sample, the index, as defined by Djankov et al. (2008), has a median value of three and ranges from one (Luxembourg) with the weakest protection to five (Spain and the United Kingdom) with the highest level of shareholder protection.
} 
represent $8.94 \%$ and $8.79 \%$ (12.27\% and 9.07\%) of the observations in the absence (presence) of excess control rights. Foundations are also less frequent in both subsamples but they exhibit an even weaker presence in banks without excess control rights (2.68\% versus $8.54 \%$ of the observations). ${ }^{22}$ In the subsample of banks without excess control rights, widely held banks represent about $20 \%$ of the observations.

Panel B of Table 3 shows that widely-held banks are much more present in countries with strong shareholder protection (59.64\% versus $40.36 \%$ ). This is consistent with the view that strong shareholder protection mitigates expropriation and therefore facilitates dispersed ownership (Shleifer and Vishny, 1997; Shleifer and Wolfenzon, 2002; La Porta et al., 2002; Shehzad et al., 2010). The level of shareholder protection does not affect the distribution of shareholder categories even though, in the absence of excess control rights, states (States) and institutional investors (Institutional) are slightly more present in countries with strong shareholder protection. In the presence of excess control rights, the data show that banks (Bank), families (Family) and states (State) prevail in countries with strong shareholder protection (respectively $68.85 \%, 63.78 \%$ and $62.46 \%$ of the observations). ${ }^{23}$

Table 4 compares the key financial characteristics for the subsamples of banks without and with excess control rights before, during, and after the crisis. It mainly shows that banks with excess control rights are less capitalized (lower equity-to-total assets ratio) during the precrisis, crisis, and post-crisis periods. ${ }^{24}$ The cost-to-income ratio (CostIncomeRatio) is not different for banks with and without excess control rights before and after the crisis. However, during the crisis banks with excess control rights have a lower cost-to-income ratio suggesting that they become significantly more cost-efficient. The table also indicates that banks with excess control rights have higher ratios of non-performing loans than other banks before and after the crisis.

[Insert Tables 3 and 4 about here]

\footnotetext{
${ }^{22}$ Our dataset indicates (not reported in the Table) that, in the subsample of banks without excess control rights, each shareholder category holds more than $50 \%$ (majority) of the cash-flow rights, consistently with the view that controlling shareholders with equal rights are more oriented to profit maximization rather than expropriation (Villalonga and Amit, 2006; Haw et al., 2010).

${ }^{23}$ Further details (not reported in Table 3) show that, consistent with the expropriation hypothesis (Claessens et al., 2002; Azofra and Santamaría, 2011), families (Family) enhance their control (higher divergence between control and cash-flow rights) in countries with weak shareholder protection rights where extraction of private benefits of control is easier.

${ }^{24}$ A deeper look at the descriptive statistics (not reported in Table 4) shows that lower equity-to-total assets ratio during the pre- and post-crisis periods is mainly attributed to family-controlled banks and to banks located in countries with weak shareholder protection but during the crisis lower equity-to-assets ratio is essentially attributable to non-family controlled banks and banks based in countries with strong protection.
} 


\subsection{Excess control rights, profitability and risk: univariate analysis}

Table 5 compares the performance (profitability and risk) of banks with and without excess control rights before, during, and after the crisis.

Before the crisis (2002-2006), banks with excess control rights have a significantly lower profitability (ROA), higher earnings volatility (the standard deviation of ROA) and higher default risk, asset risk and leverage risk (lower ZScore, Z1Score and Z2Score respectively) than banks without excess control rights. Such stylized facts are consistent with the expropriation hypothesis of divergence between control and cash-flow rights (Claessens et al., 2002; Boubakri and Ghouma, 2010; Azofra and Santamaría, 2011). However, during the crisis period (2007-2008), banks with excess control rights perform better than other banks. They exhibit a significantly higher profitability $(0.73 \%$ against $0.68 \%)$ and lower earnings volatility $(0.33 \%$ against $0.37 \%)$ than their peers, with no longer any significant difference in terms of asset, leverage and default risk. A possible explanation could be the lower incentives for controlling shareholders with excess control rights to undertake lax decisions as suggested by their higher cost-efficiency during the crisis (Table 4). Alternatively, such banks might have also benefited from private support from their ultimate controlling shareholders or their related-firms within the pyramid. After the crisis (2009-2010), banks with excess control rights are again less profitable (ROA) and more risky (higher SDROA and lower ZScore and Z2Score) than other banks suggesting that the reversed effect observed during the crisis is not persistent.

\section{[Insert Table 5 about here]}

\section{Econometric results}

We first examine the effect of excess control rights on bank profitability and risk before, during, and after the 2007-2008 global financial crisis and then look at various factors that could influence such an effect. We also investigate the changes in individual and industryadjusted bank profitability during and after the crisis and test for potential nonlinear relationships between excess control rights and bank profitability and risk.

\subsection{Effect of excess control rights on bank profitability and risk}

We estimate the coefficients of Eq. (1) using the random effects model (Generalized Least 
Square estimation method GLS) ${ }^{25}$ with robust standard errors since (i) the Fisher test rejects the null hypothesis of homogeneity in the individual dimension and (ii) the Hausman test fails to reject the null hypothesis of exogeneity of the regressors. Table 6 reports the estimation results.

Before the crisis (2002-2006), higher excess control rights are associated with poorer profitability (ROA), higher risk-taking (SDROA) and higher default risk (ZScore), as well as higher asset risk (Z1Score) and leverage risk (Z2Score): $\alpha_{1}$ is negative and significant for the profitability, default risk, asset risk and leverage risk proxies and positive and significant for the risk-taking proxy. Our results also reveal that the effect of excess control rights on profitability and risk is significantly different during the crisis and the pre-crisis periods: $\alpha_{2}$ is significant in all the regressions and carries the opposite sign to $\alpha_{1}$. Particularly, the Wald test indicates that while the effect of excess control rights on bank profitability is completely reversed during the crisis period ( $\alpha_{1}+\alpha_{2}$ is positive and significant), its positive effect on risk simply disappears ( $\alpha_{1}+\alpha_{2}$ is not significant for risk variables). Furthermore, the results indicate that the effect of excess control rights on bank profitability and risk is not different across the pre- and post-crisis periods ( $\alpha_{3}$ is not significant in all the regressions). As shown by the Wald test, after the crisis, we again find excess control rights to be negatively linked with profitability and positively with risk. These results from the recovery period highlight that the reversed effect observed during the crisis is short-lived.

The effect of excess control rights on bank profitability and risk is not only statistically significant but also economically important. For instance, considering its effect on profitability, a one standard deviation $(27.91 \%)$ increase in excess control rights decreases the profitability proxy (ROA) by $16.39 \%$ and $8.20 \%$ of its mean respectively before and after the crisis. ${ }^{26}$ During the crisis period, a one standard deviation increase in excess control rights increases the profitability proxy (ROA) by $8.20 \%$ of its mean (from $0.68 \%$ to $0.74 \%$ ).

Regarding the bank-level control variables, most of them enter significant and carry the expected sign as in previous studies. Not surprisingly, both crisis and post-crisis dummies

\footnotetext{
${ }^{25}$ Prior studies (e.g., Demsetz and Lehn 1985; Himmelberg et al. 1999; Almeida et al. 2011) highlight that ownership is endogenous because it is affected by the firm's level of profitability and risk. We hence test for the presence of endogeneity for the excess control rights variable (ExcessControl). Following Laeven and Levine (2009) and Lin et al. (2011), for each bank in a given country we use an average measure of ExcessControl obtained from all other banks in the same country to instrument ExcessControl. The Hausman test, used to determine whether the variable ExcessControl is endogenous, shows that the null hypothesis of exogeneity is not rejected.

${ }^{26}$ For example, the effect of excess control rights on profitability before the crisis is computed as follows: $\frac{\partial \mathrm{ROA}}{\partial \text { ExcessControl }}($ Crisis $=$ PostCrisis $=0)=-0.004 \times 27.91 \approx 0.11$
} 
show a drop in profitability and an increase in risk during both periods, likely because of the adverse effects of the crisis but also because banks needed to secure a higher portion of their loans after the crisis. ${ }^{27}$ The results also indicate a lower profitability (ROA) for larger banks, less volatile earnings (lower SDROA), a lower asset risk (higher Z1Score) but a higher probability of failure (lower ZScore and Z2Score). In contrast, better capitalized ${ }^{28}$ banks are $^{2}$ more profitable (higher ROA), take more risk (higher SDROA) but they are less vulnerable (higher ZScore and Z2Score). We also find banks more reliant on deposit funding to exhibit a higher profitability and a lower asset risk (higher Z1Score). While banks with a higher share of loans in total assets are less risky, banks more reliant on non-interest generating activities are more profitable but also more vulnerable (lower ZScore and Z2Score); a finding consistent with the view that an expansion into non-traditional activities leads to higher risk (Lepetit et al., 2008). Less cost-efficient banks are less profitable and more risky. As expected, we find that publicly listed banks are more profitable but more risky than privately owned banks. The dummy variables included to account for the type of the controlling shareholder are generally non-significant.

Considering the country-level control variables, some of them appear as significant. As expected, we find that the annual growth rate of the gross domestic product is positively associated with profitability (ROA) and negatively with risk. We also find that banks operating in countries with stronger shareholder protection have a higher profitability and take more risk. The results show that stronger capital oversight reduces risk. Finally, we find that banks located in countries with strong supervisory power take more risk but their probability of default is lower presumably because they are better capitalized.

To summarize, we find that the presence of excess control rights does not uniformly affect bank profitability and risk across sound and crisis periods. Specifically, in line with the entrenchment view (Claessens et al., 2002; Azofra and Santamaría 2011), our results show that being controlled by an ultimate owner with sharper divergence between control and cashflow rights contributes to lower profitability before the crisis. Our findings also indicate that it increases risk-taking and default risk. However, our results show that, during the financial crisis of 2007-2008, excess control rights had the opposite effect: they contributed to improve bank profitability without impacting risk. A possible explanation could be that entrenched

\footnotetext{
${ }^{27}$ In our sample, the ratio of loan loss provisions has increased from $0.39 \%$ before the crisis to $0.54 \%$ during the crisis and further to $0.81 \%$ after the crisis.

${ }^{28}$ Note that in the reported results, to deal with colinearity, Equity is orthogonalized with respect to bank size $(\log ($ Assets $))$.
} 
controlling shareholders were voluntarily and temporarily postponing their opportunistic behavior to keep the bank in business and benefit from future profits (Friedman et al., 2003). Alternatively, because of higher market discipline and closer supervisory scrutiny during the crisis, such shareholders might have had less latitude to pursue their own interests. Finally, our results indicate that such a reversed effect was short-lived and quickly disappeared after the crisis.

\subsection{Deeper investigation of the impact of excess control rights on profitability and risk}

In this subsection, we go deeper by investigating the factors that may affect the relationship between excess control rights and bank profitability and risk before, during, and after the crisis. We also look more closely into the changes in profitability during and after the crisis and test for the presence of non-linearity in the observed relationships.

\subsubsection{Factors influencing the effect of excess control rights on bank profitability and risk}

Consistent with the entrenchment view, our main results indicate that banks controlled by a shareholder with excess control rights underperform other banks before and after the crisis but that they outperform them during the crisis. Since entrenchment behavior might vary across owner type (Claessens et al., 2002; Villalonga and Amit, 2006) and the level of shareholder protection (La Porta et al., 2002; Dyck and Zingales, 2004), we test whether these factors affect the observed relationships during the pre-crisis, crisis, and post-crisis periods. Hence, if the observed effect is mainly due to the entrenchment behavior of the controlling shareholder, we expect it to be stronger in family-controlled banks and in banks located in countries with weak shareholder protection since expropriation is more likely to occur in these two situations. In other words, the poor performance observed before and after the crisis should be enhanced in family-controlled banks and in countries with weak shareholder protection and the reversed impact of excess control rights during the crisis should be short-lived. For this purpose, we augment Eq. (1) as follows:

$$
\begin{aligned}
Y_{i t}= & {\left[\alpha_{1}+\alpha_{2} \text { Crisis }+\alpha_{3} \text { PostCrisis }+\left(\beta_{1}+\beta_{2} \text { Crisis }+\beta_{3} \text { PostCrisis }\right) \text { Factor }\right] } \\
& \text { ExcessControl }_{i t}+\left(\delta^{\prime}+\tau^{\prime} \text { Factor }\right) \text { TDummy }+\varphi^{\prime} X+\gamma^{\prime} Z+\alpha_{0}+\varepsilon_{i t},
\end{aligned}
$$

where Factor is a dummy variable which refers to one of the two factors that are expected to affect the relationship between excess control rights and bank performance: (i) Family which takes the value of one if the bank is family-controlled, and zero otherwise; (ii) ShareRight which takes the value of one if the bank is located in a country with weak shareholder 
protection (anti-director index lower than the median value equal to three), and zero otherwise. $^{29}$ Depending on the factor we consider (family ownership or the level of shareholder protection), the parameters $\alpha_{1}, \alpha_{1}+\alpha_{2}$ and $\alpha_{1}+\alpha_{3}$ measure the effect of excess control rights on bank performance in non-family controlled banks or in countries with strong shareholder protection (Factor $=0$ ) during respectively the pre-crisis, crisis, and post-crisis periods. The parameters $\alpha_{1}+\beta_{1}, \alpha_{1}+\alpha_{2}+\beta_{1}+\beta_{2}$ and $\alpha_{1}+\alpha_{3}+\beta_{1}+\beta_{3}$ capture the effect of excess control rights on bank performance in family-controlled banks or in countries with weak shareholder protection (Factor=1) during respectively the pre-crisis, crisis, and post-crisis periods.

\section{Effect of family ownership}

Table 7 reports the results obtained from estimating Eq. (2) when we consider the owner type (family- versus non-family ownership) as the factor affecting the relationship between excess control rights and bank profitability and risk.

Consistent with our predictions, we find that the effect of excess control is enhanced in family-controlled banks independently of the period we consider. Before the crisis, although excess control rights negatively affect profitability and positively impact risk irrespective of the owner type, the results indicate that such an entrenchment behavior is aggravated in family-controlled banks ( $\beta_{1}$ is negative and significant for ROA, ZScore, Z1Score and Z2Score). During the crisis period, while the effect of excess control rights on profitability and earnings volatility simply disappears in non-family controlled banks $\left(\alpha_{1}+\alpha_{2}\right.$ is not significant in the ROA and SDROA regressions), the Wald test shows that such an effect is completely reversed in family-controlled banks: excess control rights increase profitability and reduce both earnings volatility and asset risk (Z1Score). Furthermore, the results indicate that, unlike for non-family controlled banks, the effect of excess control rights on default and leverage risks (ZScore and Z2Score) disappears in family-controlled banks during the crisis. After the crisis, family-controlled banks return to their pre-crisis performance (profitability and risk) more quickly than non-family controlled banks as shown by the Wald tests.

\section{Effect of shareholder protection rights}

Table 8 presents the results obtained from estimating Eq. (2) when the level of shareholder protection is considered as the factor affecting the relationship between excess control rights

\footnotetext{
${ }^{29}$ To allow for easier interpretation we also replace the RightsProtection index by the ShareRight binary variable in the vector of country level variables $(\mathrm{Z})$.
} 
and bank profitability and risk.

As expected, the negative impact of excess control rights on bank profitability and risk before the crisis is stronger in countries with weak shareholder protection ( $\beta_{1}$ is negative and significant for ROA, ZScore, Z1Score and Z2Score), suggesting that strong shareholder protection constrains the entrenchment behavior of shareholders with excess control rights. Similarly, while the impact of excess control rights on profitability and earnings volatility simply vanishes during the crisis in countries with strong shareholder protection $\left(\alpha_{1}+\alpha_{2}\right.$ is not significant in the ROA and SDROA regressions), it is completely reversed in countries with weak shareholder protection $\left(\alpha_{1}+\alpha_{2}\right.$ is positive and significant in the ROA and Z1Score regressions and negative and significant in the SDROA regression). Also, while the presence of excess control rights is still associated with higher default risk and leverage risk (ZScore and Z2Score) in countries with strong shareholder protection during the crisis period, such an effect disappears in countries with weak shareholder protection. This suggests that banks located in countries with weak shareholder protection and which were prone to expropriation before the crisis, were also more resilient during the crisis period compared to their peers. After the crisis, banks based in countries with weak shareholder protection return to their prior habits more quickly than those operating in a more protective environment.

\subsubsection{Changes in profitability and industry-adjusted profitability}

For deeper insights on the changes in bank profitability during and after the crisis, we estimate the following cross-section model:

$$
\mathrm{Y}_{\mathrm{i}}=\alpha_{1} \text { ExcessControl }_{\mathrm{i}}+\varphi^{\prime} \mathrm{X}_{\mathrm{i}}+\gamma^{\prime} \mathrm{Z}_{\mathrm{c}}+\alpha_{0}+\varepsilon_{\mathrm{i}},
$$

where $Y_{i}$ is either the change in profitability for bank $i$ (DROA) or the change in its performance relatively to the banking industry as a whole which is also a proxy of a change in systematic risk exposure (DROAR). ExcessControl corresponds to the difference between control and cash-flow rights as of 2006. $\mathrm{X}_{\mathrm{i}}$ and $\mathrm{Z}_{\mathrm{c}}$ are vectors of control variables averaged over the 2002-2006 period computed respectively at the bank and country levels. ${ }^{30}$

The change in bank profitability (DROA) is defined as the difference between a bank's ROA during (after) the crisis and its mean value before the crisis (2002-2006). Higher values of DROA indicate that the bank performed better during (after) the crisis than it used to do before the crisis but might also indicate that the bank suffered less during (after) the crisis. We construct DROAR on the basis of the bank's industry-adjusted profitability which is the

\footnotetext{
${ }^{30}$ Both vectors include the same set of control variables as in Eq. (1).
} 
difference between a bank's ROA and the average ROA of all the banks in our sample, both measured at the same period. The bank's industry-adjusted profitability reflects the bank's relative performance with regards to the industry for a given period. We then compute the ratio of the bank's industry-adjusted profitability during (after) the crisis to its industryadjusted profitability before the crisis. This measure captures the extent to which a given bank out- or under-performed its peers during (after) the crisis compared to its relative performance before the crisis. Higher values of the ratio indicate that the bank is more profitable compared to its peers during (after) the crisis than it used to be before the crisis but could also mean that it suffered relatively less during (after) the crisis. ${ }^{31}$ We use as indicators of individual bank profitability and industry-level profitability before the crisis the mean values of ROA at the individual- and industry-level over the 2002-2006 period.

Table 9 reports the results of estimating Eq. (3) using Ordinary Least Square method (OLS). ${ }^{32}$ We find excess control rights to be positively associated with DROA and DROAR indicating that, during the crisis, excess control rights contribute to better performance at the individual bank level but also to a better performance of banks relatively to their peers. Hence, the presence of excess control rights has apparently contributed to lower systematic risk exposure. However, the results indicate that excess control rights are no longer significantly linked with DROA and DROAR during the post-crisis period, indicating that the difference between post-crisis and pre-crisis bank profitability (DROA) and the change in relative performance with regards to peers (DROAR) are not affected by excess control rights. These results together confirm the findings from the preceding panel regression analyses.

\subsubsection{Testing for non-linearity in the relationship between excess control rights and bank performance}

We now test whether the relationship between excess control rights and bank profitability and risk depends on the extent of the shareholder's excess control rights. Previous studies (Morck et al., 1988; Adams and Santos, 2006) show that the relationship between ownership and performance (profitability and risk) is not linear. Similarly, in our study we assume that the observed entrenchment behavior is triggered only when excess control rights reach a

\footnotetext{
${ }^{31}$ To allow for easier interpretation, we define DROAR as: DROAR $i p=\frac{100-\left(\overline{\mathrm{ROA}}_{\mathrm{i}}-\overline{\mathrm{ROA}}^{\text {Industry }}\right)}{100-\left(\mathrm{ROA}_{\mathrm{ip}}-\mathrm{ROA}_{\mathrm{p}}^{\text {industry }}\right)}$, where $\mathrm{i}$ refers to the bank and $\mathrm{p}$ to the period we consider (crisis or post-crisis period). $\overline{\mathrm{ROA}}_{\mathrm{i}}$ stands for pre-crisis individual bank profitability and $\overline{\mathrm{ROA}^{\text {industry }}}$ for pre-crisis industry-level profitability.

${ }^{32}$ To compute changes in bank profitability, we restrict our sample to banks with at least one observation for ROA in each period (pre-crisis, crisis and post-crisis period). This criterion reduces our sample of banks to 480.
} 
sufficient level and that the marginal effect declines at higher levels. At very low levels, the controlling shareholder may not be entrenched and at very high levels, the relationship may even become flat. To address this potential non-linearity in the relationship between excess control rights and bank profitability and risk, we replace our variable of interest (ExcessControl) by a set of four dummy variables based on the four quartiles of the excess control rights variable $\left(\mathrm{Q}_{1}, \mathrm{Q}_{2}, \mathrm{Q}_{3}\right.$ and $\left.\mathrm{Q}_{4}\right)$ : ExcessControl $\mathrm{Q}_{1}$ equal to one if $0<$ ExcessControl $<=\mathrm{Q}_{1}$, and zero otherwise; ExcessControlQ $\mathrm{Q}_{2}$ equal to one if $\mathrm{Q}_{1}<$ ExcessControl $<=\mathrm{Q}_{2}$, and zero otherwise; ExcessControl $\mathrm{Q}_{3}$ equal to one if $\mathrm{Q}_{2}<$ ExcessControl $<=\mathrm{Q}_{3}$, and zero otherwise; and finally ExcessControl $\mathrm{Q}_{4}$ equal to one if ExcessControl $>Q_{3}$, and zero otherwise. We hence use the following model where the removed category is the group of banks without excess control rights (ExcessControl=0) which includes banks controlled by a shareholder with equal control and cash-flow rights as well as widely-held banks:

$$
\begin{aligned}
Y_{i t}= & \sum_{j=1}^{4} \alpha_{j} \text { ExcessControl }_{j}+\text { Crisis } \sum_{j=1}^{4} \beta_{j} \text { ExcessControl }_{j}+\text { PostCrisis } \\
& \sum_{j=1}^{4} \tau_{j} \text { ExcessControl }_{j}+\delta^{\prime} \text { TDummy }+\varphi^{\prime} X+\gamma^{\prime} Z+\alpha_{0}+\varepsilon_{i t}
\end{aligned}
$$

Table 10 reports the results of estimating Eq. (4). For values lower than the second quartile, the coefficients of ExcessControlQ $Q_{1}$ and ExcessControlQ $Q_{2}$ are statistically non-significant when the dependent variable is profitability (ROA) or asset risk (Z1Score). Banks controlled by a shareholder with excess control rights greater than the second quartile $\left(\mathrm{Q}_{2}\right)$ exhibit a significantly lower profitability than banks without excess control rights. For instance, before the crisis the return on average assets is $0.20 \%$ lower for a bank with excess control rights in the range $\mathrm{Q}_{2}-\mathrm{Q}_{3}$ than for a bank without excess control rights. ${ }^{33}$ Before the crisis, when the dependent variable is earnings volatility (SDROA), default risk (ZScore) or leverage risk (Z2Score), the results show that excess control rights positively affect risk even at lower levels of excess control rights $\left(\mathrm{Q}_{1}-\mathrm{Q}_{2}\right)$. Similarly, the improvement in bank profitability and risk (ROA, SDROA, ZScore and Z2Score) during the crisis is only effective for values of excess control rights greater than the second quartile $\left(\mathrm{Q}_{2}\right)$. The results also show that, after the crisis, banks controlled by a shareholder with excess control rights greater than the second quartile return to their pre-crisis habits.

\footnotetext{
${ }^{33}$ Note that when the excess control rights variable reaches the second quartile, its effect (in terms of coefficient magnitude) is almost similar independently of its range. This indicates that when excess control rights are relatively high, the relationship between excess control rights and bank profitability and risk is flat (the marginal effect of increasing excess control rights is almost null).
} 


\section{Robustness checks}

In this section, we run various regressions to check the robustness of the results obtained in Sections 4.1 and 4.2. To save space we only report the robustness for the main results obtained in Section 4.1 (see Appendix). ${ }^{34}$

First, to control for country specificities, we remove time-invariant country-level variables (RightsProtection, CapitalStringency and OfficialSupervisory) and replace them by country dummies. Considering these alternative control variables leads to almost similar conclusions (see Table A2 in the Appendix).

Second, we compute our dependent variables on the basis of 2-year rolling-window instead of 3-year rolling-window. The obtained results are consistent with our main findings (see Table A3 in the Appendix).

Third, we remove banks that benefitted from government support during the crisis (corresponding to 221 observations). Such banks might display spurious accounting information leading to biased profitability and earnings' volatility measures. Our results remain unchanged (see Table A4 in the Appendix).

Fourth, we increase the control threshold and recalculate ownership variables with a control level of $20 \%$ instead of $10 \%$. This new minimum control threshold changes our dataset both quantitatively and qualitatively ${ }^{35}$ but our main results are unchanged (see Table A5 in the Appendix). ${ }^{36}$

Finally, to check the robustness of our results, we run the regressions on sub-samples of precrisis, crisis and post-crisis periods instead of using interaction terms. Our main conclusions remain the same (see Table A6 in the Appendix).

\section{Conclusion}

The objective of this study is to empirically investigate whether the presence of ultimate shareholders with excess control rights affects bank profitability and risk and how the 20072008 financial crisis might have modified such relationships. For this purpose, we construct a dataset on ultimate control and ownership structure of 788 commercial banks based in 17 Western European countries during the 2002-2010 period which covers the pre-crisis, crisis,

\footnotetext{
${ }^{34}$ The robustness checks on Section 4.2 lead to almost similar conclusions and are available on request.

${ }^{35}$ With a threshold of $20 \%$ instead of $10 \%$, our dataset contains a higher proportion of banks considered as widely held and banks controlled by another bank. The proportion of family and state-owned banks is lower.

${ }^{36}$ Note that we also check the robustness of our results by performing further estimations using this new control threshold (20\%). We run all the checks performed with the dataset based on a $10 \%$ threshold. In all cases, our main results -not reported here and available on request- remain unchanged.
} 
and post-crisis periods.

Our findings show that, before the crisis, a larger divergence between ultimate shareholders' control and cash-flow rights is associated with lower profitability and higher risk-taking and default risk. However, our results also highlight the existence of a reversed effect: divergence between both types of rights positively impacts profitability and no longer affects risk during the crisis. A closer look into the changes in profitability indicates that excess control rights have contributed to enhance banks' performance -compared to the pre-crisis period- both individually and relatively to their peers. Our results from the recovery period (2009-2010) show that such a reversal was short-lived. Just like before the crisis, the presence of excess control rights negatively affects bank profitability and positively impacts default risk after the crisis. Further investigation shows that the relationship between excess control rights and bank profitability and risk is enhanced (i) in family-controlled banks, (ii) in countries with relatively weak shareholder protection and (iii) is only effective at intermediate and high levels of excess control rights.

As a whole, we show that ownership structure does matter in explaining cross-variation in bank performance during the 2007-2008 financial crisis. Our findings have various policy implications. First, although banks controlled via complex pyramidal arrangements might be less profitable and more risky than their peers in normal times, they also appear to be more resilient to shocks possibly because of their strong links with related firms in the pyramid. Second, bank monitoring and supervision by regulators should closely account for shareholder behavior in complex ownership structures. Furthermore, market discipline should also be enhanced by increasing the level of shareholder protection and by a better disclosure of banks' controlling shareholders and of their stakes in other banks and firms. 


\section{References}

Adams, R. B., and Santos, J. A. C. (2006). Identifying the effect of managerial control on firm performance. Journal of Accounting and Economics, 41(1-2), 55-85.

Aebi, V., Sabato, G., and Schmid, M. (2012). Risk management, corporate governance, and bank performance in the financial crisis. Journal of Banking and Finance, 36(12), 3213-3226. Albertazzi, U., and Gambacorta, L. (2009). Bank profitability and the business cycle. Journal of Financial Stability, 5(4), 393-409.

Almeida, H., Park, S. Y., Subrahmanyam, M. G., and Wolfenzon, D. (2011). The structure and formation of business groups: Evidence from Korean chaebols. Journal of Financial Economics, 99(2), 447-475.

Athanasoglou, P. P., Brissimis, S. N., and Delis, M. D. (2008). Bank-specific, industryspecific and macroeconomic determinants of bank profitability. Journal of International Financial Markets, Institutions and Money, 18, 121-136.

Azofra, V., and Santamaría, M. (2011). Ownership, control, and pyramids in Spanish commercial banks. Journal of Banking and Finance, 35(6), 1464-1476.

Bae, K.-H., Baek, J.-S., Kang, J.-K., and Liu, W.-L. (2012). Do controlling shareholders' expropriation incentives imply a link between corporate governance and firm value? Theory and evidence. Journal of Financial Economics, 105(2), 412-435.

Baek, J.-S., Kang, J.-K., and Suh Park, K. (2004). Corporate governance and firm value: evidence from the Korean financial crisis. Journal of Financial Economics, 71(2), 265-313.

Bank of International Settlements (2010a). Principles for enhancing bank corporate governance. Consultative Document.

Bank of International Settlements (2010b). $80^{\text {th }}$ Annual Report, June, Basel. Consultative Document.

Barry, T. A., Lepetit, L., and Tarazi, A. (2011). Ownership structure and risk in publicly held and privately owned banks. Journal of Banking and Finance, 35(5), 1327-1340.

Barth, J. R., Caprio, G., and Levine, R. (2001). The regulation and supervision of banks around the world: A new database. World Bank Database.

Beck, T., Demirguc-Kunt, A., and Levine, R. (2003). Law, endowments, and finance. Journal of Financial Economics, 70(2), 137-181.

Beltratti, A., and Stulz, R. M. (2012). The Credit Crisis around the Globe: Why Did Some Banks Perform Better? Journal of Financial Economics, 105(1), 1-17

Berger, A. (1995). The Relationship between capital and earnings in banking. Journal of Money, Credit and Banking, 27(2), 432-456. 
Berger, A., Imbierowicz, B., and Rauch, C. (2012). The roles of corporate governance in bank failures during the recent financial crisis. Working paper.

Berger, A. N., Hanweck, G. A., and Humphrey, D. B. (1987). Competitive viability in banking: Scale, scope, and product mix economies. Journal of Monetary Economics, 20(3), 501-520.

Bertrand, M., Mehta, P., and Mullainathan, S. (2002). Ferreting out tunneling: an application to Indian business groups. Quarterly Journal of Economics, 117(1), 121-148.

Boubakri, N., and Ghouma, H. (2010). Control/ownership structure, creditor rights protection, and the cost of debt financing: International evidence. Journal of Banking and Finance, 34(10), 2481-2499.

Bourke, P. (1989). Concentration and other determinants of bank profitability in Europe, North America and Australia. Journal of Banking and Finance, 13(1), 65-79.

Boyd, J. H., and Graham, S. L. (1986). Risk, regulation, and bank holding company expansion into nonbanking. Quarterly Review, 2-17.

Caprio, G., Laeven, L., and Levine, R. (2007). Governance and bank valuation. Journal of Financial Intermediation, 16(4), 584-617.

Claessens, S., Djankov, S., and Lang, H. P. L. (2002). Disentangling the incentive and entrenchment effects of large shareholdings. Journal of Finance, 57(6), 2741-2771.

Claessens, S., Djankov, S., and Lang, L. H. . (2000). The separation of ownership and control in East Asian corporations. Journal of Financial Economics, 58(1-2), 81-112.

Demsetz, H., and Lehn, K. (1985). The structure of corporate ownership: causes and consequences. Journal of Political Economy, 93(6), 1155-77.

Demsetz, R. S., and Strahan, P. E. (1997). Diversification, size, and risk at bank holding companies. Journal of Money, Credit and Banking, 29(3), 300-313.

Distinguin, I., Kouassi, T., and Tarazi, A. (2013). Interbank deposits and market discipline: Evidence from Central and Eastern Europe. Journal of Comparative Economics, 41(2), 544560.

Djankov, S., La Porta, R., Lopez-de-Silanes, F., and Shleifer, A. (2008). The law and economics of self-dealing. Journal of Financial Economics, 88(3), 430-465.

Dyck, A., and Zingales, L. (2004). Private benefits of control: an international comparison. Journal of Finance, 59(2), 537-600.

Erkens, D., Hung, M., and Matos, P. (2012). Corporate governance in the 2007-2008 financial crisis: Evidence from financial institutions worldwide. Journal of Corporate Finance, 18, 389411. 
Faccio, M., and Lang, L. H. . (2002). The ultimate ownership of Western European corporations. Journal of Financial Economics, 65(3), 365-395.

Fahlenbrach, R., and Stulz, R. M. (2011). Bank CEO incentives and the credit crisis. Journal of Financial Economics, 99(1), 11-26.

Friedman, E., Johnson, S., and Mitton, T. (2003). Propping and tunneling. Journal of Comparative Economics, 31(4), 732-750.

Galloway, T. M., Lee, W. B., and Roden, D. M. (1997). Banks' changing incentives and opportunities for risk taking. Journal of Banking and Finance, 21(4), 509-527.

Goyeau, D., and Tarazi, A. (1992). Evaluation du risque de défaillance bancaire en Europe. Revue d'Economie Politique, 102, 249-280.

Gropp, R., and Köhler, M. (2010). Bank owners or bank managers: who is keen on risk? Evidence from the Financial Crisis. Working paper.

Haw, I.-M., Ho, S. S. M., Hu, B., and Wu, D. (2010). Concentrated control, institutions, and banking sector: An international study. Journal of Banking and Finance, 34(3), 485-497.

Himmelberg, C. P., Hubbard, R. G., and Palia, D. (1999). Understanding the determinants of managerial ownership and the link between ownership and performance. Journal of Financial Economics, 53(3), 353-384.

Iannotta, G. (2006). Testing for opaqueness in the European banking industry. Journal of Financial Services Research, 30, 287-309.

Iannotta, G., Nocera, G., and Sironi, A. (2007). Ownership structure, risk and performance in the European banking industry. Journal of Banking and Finance, 31, 2127-2149.

Ivashina, V., and Scharfstein, D. (2010). Bank lending during the financial crisis of 2008. Journal of Financial Economics, 97(3), 319-338.

Jensen, M., and Meckling, W. (1976). Theory of the Firm: Managerial behavior, agency costs and ownership structure. Journal of Financial Economics, 3(4), 305-360.

Johnson, S., Boone, P., Breach, A., and Friedman, E. (2000). Corporate governance in the Asian financial crisis. Journal of Financial Economics, 58(1-2), 141-186.

Keeley, M. C. (1990). Deposit insurance, risk, and market power in banking. American Economic Review, 80(5), 1183-1200.

Kim, D., and Santomero, A. M. (1988). Risk in banking and capital regulation. Journal of Finance, 43(5), 1219-1233.

Koehn, M., and Santomero, A. M. (1980). Regulation of bank capital and portfolio risk. Journal of Finance, 35(5), 1235-1244. 
La Porta, R., Lopez-de-Silanes, F., and Shleifer, A. (1999). Corporate ownership around the world. Journal of Finance, 54(2), 471-517.

La Porta, R., Lopez-de-silanes, F., Shleifer, A., and Vishny, R. (2002). Investor protection and corporate valuation. Journal of Finance, 57(3), 1147-1170.

La Porta, R., Lopez-de-Silanes, F., Shleifer, A., and Vishny, R. W. (1998). Law and finance. Journal of Political Economy, 106(6), 1113-1155.

La Porta, R., Lopez-de-Silanes, F., and Zamarripa, G. (2003). Related lending. The Quarterly Journal of Economics, 118(1), 231-268.

Laeven, L. (2001). Insider lending and bank ownership: the case of Russia. Journal of Comparative Economics, 29(2), 207-229.

Laeven, L., and Levine, R. (2008). Complex ownership structures and corporate valuations. Review of Financial Studies, 21(2), 579-604.

Laeven, L., and Levine, R. (2009). Bank governance, regulation and risk taking. Journal of Financial Economics, 93(2), 259-275.

Lepetit, L., Nys, E., Rous, P., and Tarazi, A. (2008). Bank income structure and risk: An empirical analysis of European banks. Journal of Banking and Finance, 32, 1452-1467.

Lin, C., Ma, Y., Malatesta, P. H., and Xuan, Y. (2011). Ownership structure and the cost of corporate borrowing. Journal of Financial Economics, 102(2), 416-431.

McAllister, P. H., and McManus, D. (1993). Resolving the scale efficiency puzzle in banking. Journal of Banking and Finance, 17(2-3), 389-405.

Mitton, T. (2002). A cross-firm analysis of the impact of corporate governance on the East Asian financial crisis. Journal of Financial Economics, 64(2), 215-241.

Molyneux, P., and Thornton, J. (1992). Determinants of European bank profitability: a note. Journal of Banking and Finance, 16(6), 1173-1178.

Morck, R., Shleifer, A., and Vishny, R. W. (1988). Management ownership and market valuation : An empirical analysis. Journal of Financial Economics, 20(1-2), 293-315.

Morgan, D. P. (2002). Rating banks: risk and uncertainty in an opaque industry. American Economic Review, 92(4), 874-888.

Pasiouras, F., and Kosmidou, K. (2007). Factors influencing the profitability of domestic and foreign commercial banks in the European Union. Research in International Business and Finance, 21(2), 222-237.

Petrovic, A., and Tutsch, R. (2009). National rescue measures in response to the current financial crisis. European Central Bank Legal Working Paper Series, $N^{\circ} 8$, Frankfurt. 
Rajan, R. G., and Zingales, L. (1998). Which capitalism? Lessons from the East Asian crisis. Journal of Applied Corporate Finance 11, 40-48.

Shehzad, C. T., de Haan, J., and Scholtens, B. (2010). The impact of bank ownership concentration on impaired loans and capital adequacy. Journal of Banking and Finance, 34(2), 399-408.

Shleifer, A., and Vishny, R. W. (1986). Large shareholders and corporate control. Journal of Political Economy, 94(3), 461-488.

Shleifer, A., and Vishny, R. W. (1997). A Survey of Corporate Governance. Journal of Finance, 52(2), 737-783.

Shleifer, A., and Wolfenzon, D. (2002). Investor protection and equity markets. Journal of Financial Economics, 66(1), 3-27.

Stiroh, K. J. (2004). Diversification in banking: Is noninterest income the answer? Journal of Money, Credit and Banking, 36(5), 853-82.

Villalonga, B., and Amit, R. (2006). How do family ownership, control and management affect firm value? Journal of Financial Economics, 80, 385-417. 
Table 1. Distribution of European commercial banks and representativeness of the final sample

\begin{tabular}{llll}
\hline Country & All Banks & Listed Banks & Percent of total assets \\
\hline Austria & 43 & 4 & 42.746 \\
Belgium & 23 & 1 & 94.104 \\
Denmark & 47 & 36 & 94.557 \\
Finland & 4 & 1 & 82.766 \\
France & 105 & 12 & 83.358 \\
Germany & 85 & 13 & 74.834 \\
Greece & 14 & 9 & 93.013 \\
Ireland & 16 & 4 & 64.299 \\
Italy & 109 & 17 & 87.852 \\
Luxembourg & 62 & 4 & 81.714 \\
Netherlands & 27 & 5 & 70.273 \\
Norway & 7 & 3 & 72.792 \\
Portugal & 16 & 3 & 86.346 \\
Spain & 41 & 9 & 80.601 \\
Sweden & 13 & 2 & 83.119 \\
Switzerland & 86 & 4 & 86.665 \\
United Kingdom & 90 & 5 & 73.284 \\
Total/Average & $\mathbf{7 8 8}$ & $\mathbf{1 3 2}$ & $\mathbf{7 9 . 5 4}$ \\
\hline & & 9 & 5
\end{tabular}

Percent of total assets=percentage of total assets of the sample banks in a given country to the aggregate total assets of all commercial banks provided by BankScope in the same country over the 2002-2010 period. 
Table 2: Definition and descriptive statistics of the dependent and independent variables used in the regressions

\begin{tabular}{|c|c|c|c|c|c|c|c|}
\hline Variable & Description, source* and time period & Mean & Median & Std.Dev & Max & Min & Obs \\
\hline \multicolumn{8}{|c|}{ Dependent variable (\%). Source: Bankscope and authors' calculations. Period: 2002-2010 } \\
\hline ROA & $\begin{array}{l}\text { 3-year rolling-window mean of the return on average assets defined as the ratio of net income to } \\
\text { average total assets }\end{array}$ & 0.681 & 0.533 & 0.680 & 3.742 & -1.186 & 4,451 \\
\hline SDROA & 3-year rolling-window standard deviation of the return on average assets & 0.350 & 0.196 & 0.456 & 6.392 & 0.012 & 4,451 \\
\hline ZScore & $\begin{array}{l}\text { Measure of bank default risk. } \mathrm{ZScore}=(\mathrm{ROA}+(\text { equity/assets })) / \mathrm{SDROA} \text { where equity/assets is the } 3 \text {-year } \\
\text { rolling-window mean of the ratio of total equity to total assets }\end{array}$ & 66.654 & 46.374 & 65.843 & 470.673 & 1.964 & 4,451 \\
\hline Z1Score & Measure of bank asset risk. Z1Score=ROA/SDROA & 4.778 & 3.343 & 5.038 & 27.246 & -2.753 & 4,451 \\
\hline Z2Score & Measure of leverage risk. Z2Score=(equity/assets)/SDROA & 61.876 & 42.706 & 62.335 & 448.155 & 2.846 & 4,451 \\
\hline \multicolumn{8}{|c|}{ Bank specific independent variables } \\
\hline \multicolumn{8}{|c|}{ Ownership variables: Source: Bankscope, Amadeus, Annual reports and authors' calculations. Period: 2002-2006 } \\
\hline ExcessControl $(\%)$ & Difference between control and cash-flow rights & 15.968 & 0 & 27.910 & 99.995 & 0 & 4,451 \\
\hline Bank & Dummy equal to one if the largest controlling owner is a bank; and zero otherwise & 0.286 & 0 & 0.452 & 1 & 0 & 4,451 \\
\hline Family & $\begin{array}{l}\text { Dummy equal to one if the largest controlling owner is an individual, a family or a manager; and zero } \\
\text { otherwise }\end{array}$ & 0.229 & 0 & 0.420 & 1 & 0 & 4,451 \\
\hline State & Dummy equal to one if the largest controlling owner is a state or a public authority; and zero otherwise & 0.090 & 0 & 0.286 & 1 & 0 & 4,451 \\
\hline Institutional & $\begin{array}{l}\text { Dummy equal to one if the largest controlling owner is a financial company, an insurance company, a } \\
\text { mutual or a pension fund; and zero otherwise }\end{array}$ & 0.102 & 0 & 0.303 & 1 & 0 & 4,451 \\
\hline Industry & Dummy equal to one if the largest controlling owner is an industrial firm; and zero otherwise & 0.089 & 0 & 0.285 & 1 & 0 & 4,451 \\
\hline Foundation & $\begin{array}{l}\text { Dummy equal to one if the largest controlling owner is a foundation or research institute; and zero } \\
\text { otherwise }\end{array}$ & 0.055 & 0 & 0.228 & 1 & 0 & 4,451 \\
\hline \multicolumn{8}{|c|}{ Other bank specific independent variables: Period: $2002-2010$} \\
\hline Log(Assets) (Millions of Euros) & Natural logarithm of total assets & 7.760 & 7.410 & 2.227 & 14.546 & 2.681 & 4,451 \\
\hline Equity $(\%)$ & Ratio of total equity to total assets & 9.627 & 7.491 & 7.270 & 48.418 & 1.761 & 4,451 \\
\hline Deposits (\%) & Ratio of total customer deposits to total assets & 51.366 & 53.370 & 24.394 & 91.243 & 1.200 & 4,451 \\
\hline Loans $(\%)$ & Ratio of net loans to total assets & 50.880 & 55.668 & 26.224 & 94.479 & 2.032 & 4,451 \\
\hline $\mathrm{NNII}(\%)$ & Ratio of net non-interest income to net operating income & 37.769 & 33.346 & 26.581 & 108.696 & -29.018 & 4,451 \\
\hline CostIncomeRatio (\%) & Cost to income ratio & 64.348 & 63.712 & 21.443 & 351.111 & 1.266 & 4,451 \\
\hline Listed & Dummy equal to one if the bank is publicly listed; and zero otherwise & 0.200 & 0 & 0.400 & 1 & 0 & 4,451 \\
\hline Rescue & $\begin{array}{l}\text { Dummy equal to one if the bank was rescued during the 2007-2008 financial crisis; and zero otherwise. } \\
\text { Source: Petrovic and Tutsch (2009) and authors' calculations. }\end{array}$ & 0.021 & 0 & 0.145 & 1 & 0 & 4,451 \\
\hline Crisis & Dummy equal to one if the year is 2007 or 2008 ; and zero otherwise & 0.236 & 0 & 0.425 & 1 & 0 & 4,451 \\
\hline PostCrisis & Dummy equal to one if the year is 2009 or 2010 ; and zero otherwise & 0.226 & 0 & 0.418 & 1 & 0 & 4,451 \\
\hline
\end{tabular}


Country specific independent variables

GDPGrowth $(\%)$

RightsProtection

Real GDP (Growth Domestic Product) growth rate. Source: World Bank Database. Period: 2002-2010

$1.227 \quad 1.881$

2.533

6.639

$-8$.

4,451

(1) shareholders are allowed to mail in their proxy votes to the firm; (2) shareholders are not required to

1.091

1
representation of minorities in the board is allowed; (4) minority shareholders have legal mechanisms against perceived oppression by the board; (5) the minimum percentage of share capital that entitles a shareholder to call for a special shareholders' meeting is no more than $10 \%$; or (6) shareholders have preemptive rights that can be waived only by a shareholders' vote. Source: Djankov et al. (2008)

CapitalStringency

Regulatory capital stringency index. This index is the total number of affirmative answers to the

following questions: (1) Is the minimum capital ratio requirement in line with the Basel guidelines? (2)

Does the minimum ratio vary as a function of market risk? (3) Does the minimum ratio vary as a

function of credit risk? (4) Does the minimum ratio vary as a function of operational risk? (5) Is there a simple leverage ratio required? (6) Are market values of loan losses not realized in accounting books deducted from capital? (7) Are unrealized losses in securities portfolios deducted? (8) Are unrealized foreign exchange losses deducted? (9) Are accounting practices for banks in accordance with International Accounting Standards? Source: (Barth et al., 2001) and authors' calculations

OfficialSupervisory

Index of official supervisory power. This index is the total number of affirmative answers to the
following questions: (1) Does the supervisory agency have the right to meet with external auditors to discuss their report without the approval of the bank? (2) Are auditors required by law to communicate directly to the supervisory agency any presumed involvement of bank directors or senior managers in illicit activities, fraud, or insider abuse? (3) Can supervisors take legal action against external auditors for negligence? (4) Can the supervisory authority force a bank to change its internal organizational structure? (5) Are off-balance sheet items disclosed to supervisors? (6) Can the supervisory agency order the bank's directors or management to constitute provisions to cover actual or potential losses? (7) Can the supervisory agency suspend the directors' decision to distribute: (a) Dividends? (b) Bonuses? (c) Management fees? (8) Can the supervisory agency legally declare-such that this declaration supersedes the rights of bank shareholders-that a bank is insolvent? (9) Does the Banking Law give authority to the supervisory agency to intervene that is, suspend some or all ownership rights-a problem bank? (10) Regarding bank restructuring and reorganization, can the supervisory agency or any other government agency do the following: (a) Supersede shareholder rights? (b) Remove and replace management? (c) Remove and replace directors? Source: (Barth et al., 2001) and authors' calculations

\footnotetext{
${ }^{*}$ All variables are retrieved from Bankscope database unless otherwise indicated.
}

${ }^{* *}$ average assets $=($ total assets at time $\mathrm{t}+$ total assets at time $\mathrm{t}-1) / 2$ 
Table 3: Ownership characteristics by excess control rights and by the level of shareholder protection, on average, over the period $2002-2006$

\begin{tabular}{|c|c|c|c|c|c|c|c|c|c|c|c|c|}
\hline & \multicolumn{2}{|c|}{$\begin{array}{c}\text { ExcessControl }=0 \\
(2,764 \mathrm{obs})\end{array}$} & \multicolumn{2}{|c|}{$\begin{array}{c}\text { ExcessControl }>0 \\
(1,687 \mathrm{obs})\end{array}$} & \multicolumn{4}{|c|}{$\begin{array}{c}\text { ExcessControl }=0 \\
(2,764 \mathrm{obs})\end{array}$} & \multicolumn{4}{|c|}{$\begin{array}{c}\text { ExcessControl }>0 \\
(1,687 \text { obs })\end{array}$} \\
\hline & \multirow{2}{*}{\multicolumn{4}{|c|}{ PANEL A: All countries }} & \multicolumn{8}{|c|}{ PANEL B: level of shareholder protection } \\
\hline & & & & & \multicolumn{2}{|c|}{ Strong rights $(1,445 \mathrm{obs})$} & \multicolumn{2}{|c|}{ Weak rights $(1,319 \mathrm{obs})$} & \multicolumn{2}{|c|}{ Strong rights $(1,006 \mathrm{obs})$} & \multicolumn{2}{|c|}{ Weak rights (681 obs) } \\
\hline & $\begin{array}{l}\% \text { (Number) of } \\
\text { observations }\end{array}$ & $\begin{array}{l}\text { Number of } \\
\text { banks }\end{array}$ & $\begin{array}{l}\% \text { (Number) } \\
\text { of obs }\end{array}$ & $\begin{array}{l}\text { Number of } \\
\text { banks }\end{array}$ & $\begin{array}{l}\% \text { (Number) } \\
\text { of obs }\end{array}$ & $\begin{array}{l}\text { Number of } \\
\text { banks }\end{array}$ & $\begin{array}{l}\% \text { (Number) } \\
\text { of obs }\end{array}$ & $\begin{array}{l}\text { Number of } \\
\text { banks }\end{array}$ & $\begin{array}{l}\% \text { (Number) } \\
\text { of obs }\end{array}$ & $\begin{array}{l}\text { Number of } \\
\text { banks }\end{array}$ & $\begin{array}{l}\% \text { (Number) } \\
\text { of obs }\end{array}$ & $\begin{array}{l}\text { Number of } \\
\text { banks }\end{array}$ \\
\hline Bank & $\begin{array}{l}34.407 \\
(951)\end{array}$ & 195 & $\begin{array}{l}19.028 \\
(321)\end{array}$ & 73 & $\begin{array}{l}47.214 \\
(449)\end{array}$ & 101 & $\begin{array}{l}52.786 \\
(502)\end{array}$ & 94 & $\begin{array}{l}68.847 \\
(221)\end{array}$ & 47 & $\begin{array}{l}31.153 \\
(100)\end{array}$ & 26 \\
\hline Family & $\begin{array}{l}19.863 \\
(549)\end{array}$ & 117 & $\begin{array}{l}34.203 \\
(577)\end{array}$ & 139 & $\begin{array}{l}42.987 \\
(236)\end{array}$ & 52 & $\begin{array}{l}57.013 \\
(313)\end{array}$ & 65 & $\begin{array}{l}63.778 \\
(368)\end{array}$ & 81 & $\begin{array}{l}36.222 \\
(209)\end{array}$ & 58 \\
\hline State & $\begin{array}{l}4.124 \\
(114)\end{array}$ & 22 & $\begin{array}{l}16.894 \\
(285)\end{array}$ & 64 & $\begin{array}{l}68.421 \\
(78)\end{array}$ & 14 & $\begin{array}{l}31.579 \\
(36)\end{array}$ & 8 & $\begin{array}{l}62.456 \\
(178)\end{array}$ & 40 & $\begin{array}{l}37.544 \\
(107)\end{array}$ & 24 \\
\hline Institutional & $\begin{array}{l}8.936 \\
(247)\end{array}$ & 57 & $\begin{array}{l}12.270 \\
(207)\end{array}$ & 47 & $\begin{array}{l}65.182 \\
(161)\end{array}$ & 40 & $\begin{array}{l}34.818 \\
(86)\end{array}$ & 17 & $\begin{array}{l}42.512 \\
(88)\end{array}$ & 24 & $\begin{array}{l}57.488 \\
(119)\end{array}$ & 23 \\
\hline Industry & $\begin{array}{l}8.792 \\
(243)\end{array}$ & 62 & $\begin{array}{l}9.069 \\
(153)\end{array}$ & 38 & $\begin{array}{l}55.967 \\
(136)\end{array}$ & 35 & $\begin{array}{l}44.033 \\
(107)\end{array}$ & 27 & $\begin{array}{l}54.902 \\
(84)\end{array}$ & 23 & $\begin{array}{l}45.098 \\
(69)\end{array}$ & 15 \\
\hline Foundation & $\begin{array}{l}2.677 \\
(100)\end{array}$ & 18 & $\begin{array}{l}8.536 \\
(144)\end{array}$ & 30 & $\begin{array}{l}33.784 \\
(51)\end{array}$ & 9 & $\begin{array}{l}66.216 \\
(49)\end{array}$ & 9 & $\begin{array}{l}46.528 \\
(67)\end{array}$ & 13 & $\begin{array}{l}53.472 \\
(77)\end{array}$ & 17 \\
\hline Widely & $\begin{array}{l}20.260 \\
(560)\end{array}$ & 126 & - & & $\begin{array}{l}59.643 \\
(334)\end{array}$ & & $\begin{array}{l}40.357 \\
(226)\end{array}$ & & & & & \\
\hline
\end{tabular}

Subsamples definition: A bank is classified as without excess control rights (ExcessControl=0) if it is controlled by an ultimate owner with equal control and cash-flow rights or if it is widely held. A bank is classified as with excess control rights (ExcessControl>0) if it is controlled by an ultimate owner with greater control rights than cash-flow rights. Strong rights (Weak rights) refer to banks located in countries with above-median (below-median) value of the shareholder protection index.

Variables definition: Bank=the largest ultimate controlling owner is a bank; Family=the largest ultimate controlling owner is an individual, a family or a manager; State=the largest ultimate controlling owner is a state or a public authority; Institutional=the largest ultimate controlling owner is a financial company, an insurance company, a mutual or a pension fund; Industry=the largest ultimate controlling owner is an industrial firm; Foundation=the largest ultimate controlling owner is a foundation or a research institute; Widely=the bank itself is widely held. 
Table 4: Key financial characteristics of banks without and with excess control rights, on average, across the pre-crisis, crisis and post-crisis periods

\begin{tabular}{|c|c|c|c|c|c|c|c|c|c|}
\hline & \multicolumn{3}{|c|}{ Pre-crisis period (2002-2006) } & \multicolumn{3}{|c|}{ Crisis period (2007-2008) } & \multicolumn{3}{|c|}{ Post-crisis period (2009-2010) } \\
\hline & $\begin{array}{l}\text { ExcessControl=0 } \\
\text { (0) }\end{array}$ & $\begin{array}{l}\text { ExcessControl>0 } \\
\text { (1) }\end{array}$ & $\begin{array}{l}\text { T-stat } \\
(0)-(1)\end{array}$ & $\begin{array}{l}\text { ExcessControl=0 } \\
(0)\end{array}$ & $\begin{array}{l}\text { ExcessControl }>0 \\
\text { (1) }\end{array}$ & $\begin{array}{l}\text { T-stat } \\
(0)-(1)\end{array}$ & $\begin{array}{l}\text { ExcessControl=0 } \\
(0)\end{array}$ & $\begin{array}{l}\text { ExcessControl>0 } \\
\text { (1) }\end{array}$ & $\begin{array}{l}\text { T-stat } \\
(0)-(1)\end{array}$ \\
\hline Assets & 38393.292 & 36383.871 & 0.231 & 44698.885 & 34286.501 & 0.979 & 50852.099 & 47046.177 & 0.303 \\
\hline Equity & 10.577 & 8.763 & $2.429^{* *}$ & 9.932 & 8.334 & $3.537^{* * *}$ & 9.658 & 8.732 & $2.186^{* *}$ \\
\hline Deposits & 52.693 & 47.534 & $5.025^{* * * *}$ & 53.612 & 47.354 & $4.040^{* * *}$ & 54.942 & 49.797 & $3.320^{* * * *}$ \\
\hline Loans & 51.848 & 48.335 & 1.249 & 52.150 & 51.625 & 0.311 & 51.650 & 48.945 & 1.566 \\
\hline NNII & 38.222 & 38.104 & 0.106 & 35.801 & 35.665 & 0.079 & 38.414 & 39.684 & -0.731 \\
\hline CostIncomeRatio & 64.491 & 64.461 & 0.034 & 65.697 & 61.146 & $3.042^{* * *}$ & 64.569 & 64.172 & 0.098 \\
\hline NPL & 2.901 & 3.592 & $-2.426^{* *}$ & 3.330 & 3.410 & -0.255 & 3.157 & 3.643 & $-1.974^{*}$ \\
\hline
\end{tabular}

Subsamples definition: A bank is classified as without excess control rights (ExcessControl=0) if it is controlled by an ultimate owner with equal control and cash-flow rights or if it is widely held. A bank is classified as with excess control rights (ExcessControl>0) if it is controlled by an ultimate owner with greater control rights than cash-flow rights.

T-stat tests for the null: "bank financial characteristics are not different between banks without and with excess control rights during the pre-crisis, the crisis and post-crisis periods"; ${ }^{* * *},{ }^{* *}$ and ${ }^{*}$ indicate significance at the $1 \%, 5 \%$ and $10 \%$ levels, respectively, for a bilateral test.

Variables definition: All variables are expressed in percentages except Assets which is in millions of Euros. Assets=bank's total assets; Equity=ratio of total equity to total assets; Deposits=ratio of customer deposits to total assets; Loans=ratio of net loans to total assets; NNII=ratio of net non-interest income to net operating income; CostIncomeRatio=cost to income ratio; NPL=ratio of non-performing loans to gross loans. 
Table 5: Profitability and risk by excess control rights across the pre-crisis, crisis and post-crisis periods

\begin{tabular}{|c|c|c|c|c|c|c|c|c|c|}
\hline & \multicolumn{3}{|c|}{ Pre-crisis period (2002-2006) } & \multicolumn{3}{|c|}{ Crisis period (2007-2008) } & \multicolumn{3}{|c|}{ Post-crisis period (2009-2010) } \\
\hline & ExcessControl $=0$ & ExcessControl $>0$ & T-statistics & ExcessControl $=0$ & ExcessControl>0 & T-statistics & ExcessControl $=0$ & ExcessControl $>0$ & T-statistics \\
\hline ROA & 0.831 & 0.645 & $6.403^{* * *}$ & 0.684 & 0.734 & $-2.056^{* *}$ & 0.479 & 0.410 & $1.923^{*}$ \\
\hline SDROA & 0.338 & 0.385 & $-2.631^{* * *}$ & 0.365 & 0.327 & $2.235^{* *}$ & 0.369 & 0.400 & $-2.094^{* *}$ \\
\hline ZScore & 71.989 & 56.807 & $5.473^{* * *}$ & 65.642 & 63.463 & 0.774 & 67.064 & 51.827 & $4.455^{* * * *}$ \\
\hline Z1Score & 5.070 & 3.830 & $2.242^{* *}$ & 4.519 & 4.388 & 0.076 & 4.010 & 4.017 & -0.022 \\
\hline Z2Score & 66.919 & 52.977 & $5.638^{* * * *}$ & 61.123 & 59.075 & 0.931 & 63.054 & 47.810 & $4.711^{* * *}$ \\
\hline
\end{tabular}

Subsamples definition: A bank is classified as without excess control rights (ExcessControl=0) if it is controlled by an ultimate owner with equal control and cash-flow rights or if it is widely held. A bank is classified as with excess control rights (ExcessControl>0) if it is controlled by an ultimate owner with greater control rights than cash-flow rights.

T-stat tests for the null: "bank profitability and risk are not different between banks with and without excess control rights during the pre-crisis, the crisis and post-crisis periods"; ${ }^{* * *},{ }^{* *}$ and ${ }^{*}$ indicate significance at the $1 \%, 5 \%$ and $10 \%$ levels, respectively, for a bilateral test.

Variables definition: All variables are expressed in percentages. ROA=3-year rolling-window mean of the return on average assets; SDROA=3-year rolling-window standard deviation of the return on average assets; ZScore=measure of bank default risk; Z1Score=measure of bank asset risk; Z2Score=measure of leverage risk. 
Table 6: Excess control rights, bank profitability and risk (2002-2010, GLS)

$\mathrm{Y}_{\mathrm{it}}=\left(\alpha_{1}+\alpha_{2}\right.$ Crisis $+\alpha_{3}$ PostCrisis $)$ ExcessControl ${ }_{i \mathrm{it}}+\delta^{\prime}$ TDummy $+\varphi^{\prime} \mathrm{X}+\gamma^{\prime} \mathrm{Z}+\alpha_{0}+\varepsilon_{\mathrm{it}}$

\begin{tabular}{|c|c|c|c|c|c|}
\hline Dependent variable (Y) & ROA & SDROA & ZScore & Z1Score & Z2Score \\
\hline ExcessControl $\left(\alpha_{1}\right)$ & $\begin{array}{l}-0.004^{* * *} \\
(0.000)\end{array}$ & $\begin{array}{l}0.001^{* * *} \\
(0.009)\end{array}$ & $\begin{array}{l}-0.270^{* * * *} \\
(0.000)\end{array}$ & $\begin{array}{l}-0.010^{* *} \\
(0.040)\end{array}$ & $\begin{array}{l}-0.260^{* * * *} \\
(0.000)\end{array}$ \\
\hline Crisis $\times$ ExcessControl $\left(\alpha_{2}\right)$ & $\begin{array}{l}0.006^{* * *} \\
(0.000)\end{array}$ & $\begin{array}{l}-0.002^{\text {**** }} \\
(0.000)\end{array}$ & $\begin{array}{l}0.131^{* * *} \\
(0.040)\end{array}$ & $\begin{array}{l}0.008^{* *} \\
(0.046)\end{array}$ & $\begin{array}{l}0.123^{* * *} \\
(0.045)\end{array}$ \\
\hline PostCrisis $\times$ ExcessControl $\left(\alpha_{3}\right)$ & $\begin{array}{l}0.002 \\
(0.107)\end{array}$ & $\begin{array}{l}0.000 \\
(0.836)\end{array}$ & $\begin{array}{l}0.049 \\
(0.321)\end{array}$ & $\begin{array}{l}0.004 \\
(0.386)\end{array}$ & $\begin{array}{l}0.046 \\
(0.319)\end{array}$ \\
\hline Crisis $\left(\delta_{1}\right)$ & $\begin{array}{l}-0.177^{* * * *} \\
(0.000)\end{array}$ & $\begin{array}{l}0.028^{*} \\
(0.059)\end{array}$ & $\begin{array}{l}-4.528^{* *} \\
(0.046)\end{array}$ & $\begin{array}{l}-0.520^{*} \\
(0.042)\end{array}$ & $\begin{array}{l}-4.008^{* *} \\
(0.049)\end{array}$ \\
\hline PostCrisis $\left(\delta_{2}\right)$ & $\begin{array}{l}-0.295^{* * *} \\
(0.000)\end{array}$ & $\begin{array}{l}0.043^{* * * *} \\
(0.005)\end{array}$ & $\begin{array}{l}-7.145^{* *} \\
(0.040)\end{array}$ & $\begin{array}{l}-1.032^{* * * *} \\
(0.000)\end{array}$ & $\begin{array}{l}-6.113^{* *} \\
(0.045)\end{array}$ \\
\hline $\log ($ Assets $)\left(\varphi_{1}\right)$ & $\begin{array}{l}-0.102^{* * *} \\
(0.000)\end{array}$ & $\begin{array}{l}-0.057^{* * *} \\
(0.000)\end{array}$ & $\begin{array}{l}-1.818^{* *-} \\
(0.021)\end{array}$ & $\begin{array}{l}0.166^{* * *} \\
(0.004)\end{array}$ & $\begin{array}{l}-1.974^{* * * *} \\
(0.009)\end{array}$ \\
\hline Equity $\left(\varphi_{2}\right)$ & $\begin{array}{l}0.218^{* * * *} \\
(0.000)\end{array}$ & $\begin{array}{l}0.064^{* * * *} \\
(0.000)\end{array}$ & $\begin{array}{l}5.011^{* * *} \\
(0.003)\end{array}$ & $\begin{array}{l}0.007 \\
(0.941)\end{array}$ & $\begin{array}{l}4.962^{* * *} \\
(0.002)\end{array}$ \\
\hline Deposits $\left(\varphi_{3}\right)$ & $\begin{array}{l}0.002^{* * * *} \\
(0.000)\end{array}$ & $\begin{array}{l}0.000 \\
(0.936)\end{array}$ & $\begin{array}{l}0.096 \\
(0.116)\end{array}$ & $\begin{array}{l}0.018^{* * * *} \\
(0.000)\end{array}$ & $\begin{array}{l}0.081 \\
(0.157)\end{array}$ \\
\hline Loans $\left(\varphi_{4}\right)$ & $\begin{array}{l}0.001 \\
(0.120)\end{array}$ & $\begin{array}{l}-0.002^{* * * *} \\
(0.001)\end{array}$ & $\begin{array}{l}0.304^{* * * *} \\
(0.000)\end{array}$ & $\begin{array}{l}0.023^{* * * *} \\
(0.000)\end{array}$ & $\begin{array}{l}0.278^{* * * *} \\
(0.000)\end{array}$ \\
\hline $\mathrm{NNII}\left(\varphi_{5}\right)$ & $\begin{array}{l}0.003^{* * *} \\
(0.000)\end{array}$ & $\begin{array}{l}0.000 \\
(0.226)\end{array}$ & $\begin{array}{l}-0.101^{* *} \\
(0.011)\end{array}$ & $\begin{array}{l}0.004 \\
(0.238)\end{array}$ & $\begin{array}{l}-0.101^{* * *} \\
(0.007)\end{array}$ \\
\hline CostIncomeRatio $\left(\varphi_{6}\right)$ & $\begin{array}{l}-0.013^{* * *} \\
(0.000)\end{array}$ & $\begin{array}{l}0.001^{* * * *} \\
(0.004)\end{array}$ & $\begin{array}{l}-0.243^{* * * *} \\
(0.000)\end{array}$ & $\begin{array}{l}-0.046^{* * * *} \\
(0.000)\end{array}$ & $\begin{array}{l}-0.200^{* * * *} \\
(0.000)\end{array}$ \\
\hline Listed $\left(\varphi_{7}\right)$ & $\begin{array}{l}0.178^{* * *} \\
(0.000)\end{array}$ & $\begin{array}{l}0.050^{*} \\
(0.096)\end{array}$ & $\begin{array}{l}-18.752^{* * *} \\
(0.000)\end{array}$ & $\begin{array}{l}-0.246 \\
(0.501)\end{array}$ & $\begin{array}{l}-18.473^{* * *} \\
(0.000)\end{array}$ \\
\hline Rescue $\left(\varphi_{8}\right)$ & $\begin{array}{l}0.024 \\
(0.649)\end{array}$ & $\begin{array}{l}-0.009 \\
(0.833)\end{array}$ & $\begin{array}{l}-3.234 \\
(0.533)\end{array}$ & $\begin{array}{l}-0.364 \\
(0.540)\end{array}$ & $\begin{array}{l}-2.832 \\
(0.543)\end{array}$ \\
\hline $\operatorname{Bank}\left(\varphi_{9}\right)$ & $\begin{array}{l}0.032 \\
(0.435)\end{array}$ & $\begin{array}{l}0.009 \\
(0.757)\end{array}$ & $\begin{array}{l}-4.390 \\
(0.436)\end{array}$ & $\begin{array}{l}0.058 \\
(0.880)\end{array}$ & $\begin{array}{l}-4.372 \\
(0.413)\end{array}$ \\
\hline Family $\left(\varphi_{10}\right)$ & $\begin{array}{l}0.034 \\
(0.435)\end{array}$ & $\begin{array}{l}0.021 \\
(0.475)\end{array}$ & $\begin{array}{l}-1.717 \\
(0.770)\end{array}$ & $\begin{array}{l}0.290 \\
(0.492)\end{array}$ & $\begin{array}{l}-1.856 \\
(0.737)\end{array}$ \\
\hline State $\left(\varphi_{11}\right)$ & $\begin{array}{l}0.038 \\
(0.550)\end{array}$ & $\begin{array}{l}0.012 \\
(0.776)\end{array}$ & $\begin{array}{l}-2.831 \\
(0.694)\end{array}$ & $\begin{array}{l}-0.627 \\
(0.207)\end{array}$ & $\begin{array}{l}-2.081 \\
(0.762)\end{array}$ \\
\hline Institutional $\left(\varphi_{12}\right)$ & $\begin{array}{l}0.004 \\
(0.934)\end{array}$ & $\begin{array}{l}0.011 \\
(0.756)\end{array}$ & $\begin{array}{l}-4.192 \\
(0.465)\end{array}$ & $\begin{array}{l}-0.233 \\
(0.603)\end{array}$ & $\begin{array}{l}-3.842 \\
(0.475)\end{array}$ \\
\hline Industry $\left(\varphi_{13}\right)$ & $\begin{array}{l}0.016 \\
(0.786)\end{array}$ & $\begin{array}{l}0.069 \\
(0.144)\end{array}$ & $\begin{array}{l}-3.162 \\
(0.651)\end{array}$ & $\begin{array}{l}0.254 \\
(0.607)\end{array}$ & $\begin{array}{l}-3.371 \\
(0.609)\end{array}$ \\
\hline Foundation $\left(\varphi_{14}\right)$ & $\begin{array}{l}0.035 \\
(0.593)\end{array}$ & $\begin{array}{l}-0.062 \\
(0.121)\end{array}$ & $\begin{array}{l}12.246 \\
(0.207)\end{array}$ & $\begin{array}{l}0.386 \\
(0.541)\end{array}$ & $\begin{array}{l}11.920 \\
(0.192)\end{array}$ \\
\hline GDPGrowth $\left(\gamma_{1}\right)$ & $\begin{array}{l}0.013^{\text {*ak }} \\
(0.000)\end{array}$ & $\begin{array}{l}-0.005^{* * *} \\
(0.010)\end{array}$ & $\begin{array}{l}0.944^{* * *} \\
(0.007)\end{array}$ & $\begin{array}{l}0.075^{\text {*w* }} \\
(0.007)\end{array}$ & $\begin{array}{l}0.875^{\text {*a* }} \\
(0.008)\end{array}$ \\
\hline RightsProtection $\left(\gamma_{2}\right)$ & $\begin{array}{l}0.036^{* *} \\
(0.013)\end{array}$ & $\begin{array}{l}0.033^{* * *} \\
(0.004)\end{array}$ & $\begin{array}{l}-1.564 \\
(0.278)\end{array}$ & $\begin{array}{l}-0.230 \\
(0.138)\end{array}$ & $\begin{array}{l}-1.305 \\
(0.343)\end{array}$ \\
\hline CapitalStringency $\left(\gamma_{3}\right)$ & $\begin{array}{l}-0.016 \\
(0.112)\end{array}$ & $\begin{array}{l}-0.017^{* *} \\
(0.030)\end{array}$ & $\begin{array}{l}2.812^{* * *} \\
(0.007)\end{array}$ & $\begin{array}{l}0.222^{* * * *} \\
(0.009)\end{array}$ & $\begin{array}{l}2.576^{* * * *} \\
(0.009)\end{array}$ \\
\hline OfficialSupervisory $\left(\gamma_{4}\right)$ & $\begin{array}{l}0.006 \\
(0.477)\end{array}$ & $\begin{array}{l}0.018^{* * * *} \\
(0.005)\end{array}$ & $\begin{array}{l}2.487^{* *} \\
(0.029)\end{array}$ & $\begin{array}{l}0.030 \\
(0.616)\end{array}$ & $\begin{array}{l}2.449^{* * *} \\
(0.025)\end{array}$ \\
\hline Intercept $\left(\alpha_{0}\right)$ & $\begin{array}{l}2.048^{* * *} \\
(0.000)\end{array}$ & $\begin{array}{l}0.592^{* * *} \\
(0.000)\end{array}$ & $\begin{array}{l}46.819^{* * *} \\
(0.010)\end{array}$ & $\begin{array}{l}3.114^{*} \\
(0.011)\end{array}$ & $\begin{array}{l}43.546^{* *} \\
(0.011)\end{array}$ \\
\hline $\begin{array}{l}\text { Number of observations } \\
\text { Number of banks } \\
\text { R-square (overall) }\end{array}$ & $\begin{array}{l}4,451 \\
788 \\
0.395\end{array}$ & $\begin{array}{l}4,451 \\
788 \\
0.204\end{array}$ & $\begin{array}{l}4,451 \\
788 \\
0.074\end{array}$ & $\begin{array}{l}4,451 \\
788 \\
0.119\end{array}$ & $\begin{array}{l}4,451 \\
788 \\
0.077\end{array}$ \\
\hline $\begin{array}{r}\text { Wald tests : } \\
\begin{array}{r}\alpha_{1}+\alpha_{2} \\
\text { P-value } \\
\alpha_{1}+\alpha_{3} \\
\text { P-value }\end{array}\end{array}$ & $\begin{array}{l}0.002^{* *} \\
(0.033) \\
-0.002^{* * * *} \\
(0.001)\end{array}$ & $\begin{array}{l}-0.001 \\
(0.100) \\
0.001^{* * *} \\
(0.044)\end{array}$ & $\begin{array}{l}-0.139 \\
(0.101) \\
-0.221^{* * *} \\
(0.000)\end{array}$ & $\begin{array}{l}-0.002 \\
(0.692) \\
-0.006 \\
(0.300)\end{array}$ & $\begin{array}{l}-0.137 \\
(0.106) \\
-0.214^{* * *} \\
(0.000)\end{array}$ \\
\hline
\end{tabular}

Variables definition: ROA=3-year rolling-window mean of the return on average assets; SDROA=3-year rolling-window standard deviation of the return on average assets; ZScore=measure of bank default risk; Z1Score $=$ measure of bank asset risk; Z2Score $=$ measure of leverage risk; ExcessControl=difference between control and cash-flow rights; Crisis=dummy equal to one if the year is 2007 or 2008 , and zero otherwise; PostCrisis=dummy equal to one if the year is 2009 or 2010, and zero otherwise; $\log ($ Assets $)=$ natural logarithm of total assets; Equity=ratio of total equity to total assets; Deposits=ratio of customer deposits to total assets; Loans=ratio of net loans to total assets; NNII=ratio of net non-interest income to net operating income; CostIncomeRatio=cost to income ratio; Listed=dummy equal to one if the bank is publicly listed, and zero otherwise; Rescue=dummy equal to one if the bank was rescued during the 2007-2008 financial crisis, and zero otherwise; Bank-Foundation is a set of dummy variables representing the type of the largest ultimate owner (Widely is the benchmark group); GDPGrowth=real GDP growth rate; RightsProtection=anti-director index of the level of shareholder protection; CapitalStringency=regulatory capital stringency index; OfficialSupervisory=index of official supervisory power. P-values based on robust standard errors are shown in parentheses. ${ }^{* * *},{ }^{* *}$ and ${ }^{*}$ indicate significance respectively at the $1 \%, 5 \%$ and $10 \%$ levels. 
Table 7: Excess control rights, bank profitability and risk (2002-2010, GLS): effect of family-ownership $Y_{\text {it }}=\left[\alpha_{1}+\alpha_{2}\right.$ Crisis $+\alpha_{3}$ PostCrisis $+\left(\beta_{1}+\beta_{2}\right.$ Crisis $+\beta_{3}$ PostCrisis $)$ Family $]$ ExcessControl $_{i t}+\left(\delta^{\prime}+\right.$ $\tau^{\prime}$ Family)TDummy $+\varphi^{\prime} \mathrm{X}+\gamma^{\prime} \mathrm{Z}+\alpha_{0}+\varepsilon_{\text {it }}$

\begin{tabular}{|c|c|c|c|c|c|}
\hline Dependent variable (Y) & ROA & SDROA & ZScore & Z1Score & Z2Score \\
\hline ExcessControl $\left(\alpha_{1}\right)$ & $-0.003^{* * *}$ & $\begin{array}{l}0.001^{*} \\
(0.084)\end{array}$ & $-0.233^{* * *}$ & $-0.007^{*}$ & $-0.226^{* * *}$ \\
\hline Family $\times$ ExcessControl $\left(\beta_{1}\right)$ & $\begin{array}{l}-0.003^{* *} \\
(0.033)\end{array}$ & $\begin{array}{l}(0.084) \\
0.001 \\
(0.170)\end{array}$ & $\begin{array}{l}(0.000) \\
-0.140^{*} \\
(0.087)\end{array}$ & $\begin{array}{l}(0.059) \\
-0.010^{*} \\
(0.085)\end{array}$ & $\begin{array}{l}(0.000) \\
-0.130^{*} \\
(0.091)\end{array}$ \\
\hline Crisis $\times$ ExcessControl $\left(\alpha_{2}\right)$ & $\begin{array}{l}0.004^{*} \\
(0.072)\end{array}$ & $\begin{array}{l}-0.001 \\
(0.188)\end{array}$ & $\begin{array}{l}0.052 \\
(0.200)\end{array}$ & $\begin{array}{l}0.009 \\
(0.278)\end{array}$ & $\begin{array}{l}0.043 \\
(0.200)\end{array}$ \\
\hline Crisis $\times$ Family $\times$ ExcessControl $\left(\beta_{2}\right)$ & $\begin{array}{l}0.005^{* * * *} \\
(0.000)\end{array}$ & $\begin{array}{l}-0.002^{* * * *} \\
(0.001)\end{array}$ & $\begin{array}{l}0.185^{* *} \\
(0.048)\end{array}$ & $\begin{array}{l}0.015^{*} \\
(0.064)\end{array}$ & $\begin{array}{l}0.170^{*} \\
(0.051)\end{array}$ \\
\hline PostCrisis $\times$ ExcessControl $\left(\alpha_{3}\right)$ & $\begin{array}{l}0.002^{*} \\
(0.085)\end{array}$ & $\begin{array}{l}0.000 \\
(0.353)\end{array}$ & $\begin{array}{l}0.032 \\
(0.577)\end{array}$ & $\begin{array}{l}0.003 \\
(0.523)\end{array}$ & $\begin{array}{l}0.029 \\
(0.585)\end{array}$ \\
\hline PostCrisis $\times$ Family $\times$ ExcessControl $\left(\beta_{3}\right)$ & $\begin{array}{l}0.001 \\
(0.127)\end{array}$ & $\begin{array}{l}0.002 \\
(0.355)\end{array}$ & $\begin{array}{l}0.089 \\
(0.488)\end{array}$ & $\begin{array}{l}0.006 \\
(0.381)\end{array}$ & $\begin{array}{l}0.083 \\
(0.469)\end{array}$ \\
\hline Crisis $\left(\delta_{1}\right)$ & $\begin{array}{l}-0.189^{* * *} \\
(0.000)\end{array}$ & $\begin{array}{l}0.015 \\
(0.349)\end{array}$ & $\begin{array}{l}-4.497 \\
(0.196)\end{array}$ & $\begin{array}{l}-0.523^{*} \\
(0.069)\end{array}$ & $\begin{array}{l}-4.021 \\
(0.215)\end{array}$ \\
\hline PostCrisis $\left(\delta_{2}\right)$ & $\begin{array}{l}-0.292^{* * *} \\
(0.000)\end{array}$ & $\begin{array}{l}0.022 \\
(0.172)\end{array}$ & $\begin{array}{l}0.358 \\
(0.905)\end{array}$ & $\begin{array}{l}-0.912^{* * *} \\
(0.000)\end{array}$ & $\begin{array}{l}1.281 \\
(0.647)\end{array}$ \\
\hline Family $\times$ Crisis $\left(\tau_{1}\right)$ & $\begin{array}{l}0.056 \\
(0.274)\end{array}$ & $\begin{array}{l}0.055^{*} \\
(0.088)\end{array}$ & $\begin{array}{l}-4.540 \\
(0.486)\end{array}$ & $\begin{array}{l}-0.034 \\
(0.939)\end{array}$ & $\begin{array}{l}-4.533 \\
(0.464)\end{array}$ \\
\hline Family $\times$ PostCrisis $\left(\tau_{2}\right)$ & $\begin{array}{l}-0.012 \\
(0.847)\end{array}$ & $\begin{array}{l}0.091^{* * *} \\
(0.006)\end{array}$ & $\begin{array}{l}-10.837^{* *} \\
(0.048)\end{array}$ & $\begin{array}{l}-0.518 \\
(0.230)\end{array}$ & $\begin{array}{l}-10.336^{* *} \\
(0.043)\end{array}$ \\
\hline $\log ($ Assets $)\left(\varphi_{1}\right)$ & $\begin{array}{l}-0.102^{* * k} \\
(0.000)\end{array}$ & $\begin{array}{l}-0.057^{* * 3} \\
(0.000)\end{array}$ & $\begin{array}{l}-1.779^{* *} \\
(0.024)\end{array}$ & $\begin{array}{l}0.167^{\text {*3 }} \\
(0.004)\end{array}$ & $\begin{array}{l}-1.935^{\text {*** }} \\
(0.010)\end{array}$ \\
\hline Equity $\left(\varphi_{2}\right)$ & $\begin{array}{l}0.218^{* * * *} \\
(0.000)\end{array}$ & $\begin{array}{l}0.064^{* * *} \\
(0.000)\end{array}$ & $\begin{array}{l}4.987^{* * *} \\
(0.003)\end{array}$ & $\begin{array}{l}0.002 \\
(0.984)\end{array}$ & $\begin{array}{l}4.941^{* * * *} \\
(0.002)\end{array}$ \\
\hline Deposits $\left(\varphi_{3}\right)$ & $\begin{array}{l}0.002^{\text {**** }} \\
(0.000)\end{array}$ & $\begin{array}{l}0.000 \\
(0.898)\end{array}$ & $\begin{array}{l}0.096 \\
(0.117)\end{array}$ & $\begin{array}{l}0.018^{* * * *} \\
(0.000)\end{array}$ & $\begin{array}{l}0.082 \\
(0.155)\end{array}$ \\
\hline Loans $\left(\varphi_{4}\right)$ & $\begin{array}{l}0.001 \\
(0.133)\end{array}$ & $\begin{array}{l}-0.002^{* * * *} \\
(0.001)\end{array}$ & $\begin{array}{l}0.305^{* * * *} \\
(0.000)\end{array}$ & $\begin{array}{l}0.023^{* * *} \\
(0.000)\end{array}$ & $\begin{array}{l}0.280^{* * * *} \\
(0.000)\end{array}$ \\
\hline $\mathrm{NNII}\left(\varphi_{5}\right)$ & $\begin{array}{l}0.003^{* * *} \\
(0.000)\end{array}$ & $\begin{array}{l}0.000 \\
(0.235)\end{array}$ & $\begin{array}{l}-0.100^{* *} \\
(0.012)\end{array}$ & $\begin{array}{l}0.004 \\
(0.243)\end{array}$ & $\begin{array}{l}-0.099^{* * *} \\
(0.008)\end{array}$ \\
\hline CostIncomeRatio $\left(\varphi_{6}\right)$ & $\begin{array}{l}-0.013^{* * * *} \\
(0.000)\end{array}$ & $\begin{array}{l}0.001^{* * *} \\
(0.004)\end{array}$ & $\begin{array}{l}-0.241^{* * *} \\
(0.000)\end{array}$ & $\begin{array}{l}-0.046^{* * * *} \\
(0.000)\end{array}$ & $\begin{array}{l}-0.198^{* * *} \\
(0.000)\end{array}$ \\
\hline Listed $\left(\varphi_{7}\right)$ & $\begin{array}{l}0.178^{* * * *} \\
(0.000)\end{array}$ & $\begin{array}{l}0.054^{*} \\
(0.069)\end{array}$ & $\begin{array}{l}-19.025^{* * *} \\
(0.000)\end{array}$ & $\begin{array}{l}-0.261 \\
(0.471)\end{array}$ & $\begin{array}{l}-18.734^{* * *} \\
(0.000)\end{array}$ \\
\hline Rescue $\left(\varphi_{8}\right)$ & $\begin{array}{l}0.035 \\
(0.508)\end{array}$ & $\begin{array}{l}-0.007 \\
(0.866)\end{array}$ & $\begin{array}{l}-3.597 \\
(0.493)\end{array}$ & $\begin{array}{l}-0.390 \\
(0.510)\end{array}$ & $\begin{array}{l}-3.170 \\
(0.502)\end{array}$ \\
\hline GDPGrowth $\left(\gamma_{1}\right)$ & $\begin{array}{l}0.013^{\text {*** }} \\
(0.000)\end{array}$ & $\begin{array}{l}-0.005^{*} \\
(0.010)\end{array}$ & $\begin{array}{l}0.946^{\text {*k* }} \\
(0.007)\end{array}$ & $\begin{array}{l}0.075^{* * *} \\
(0.007)\end{array}$ & $\begin{array}{l}0.877^{\text {*** }} \\
(0.008)\end{array}$ \\
\hline RightsProtection $\left(\gamma_{2}\right)$ & $\begin{array}{l}0.037^{* *} \\
(0.012)\end{array}$ & $\begin{array}{l}0.032^{* * *} \\
(0.006)\end{array}$ & $\begin{array}{l}-1.509 \\
(0.300)\end{array}$ & $\begin{array}{l}-0.221^{* *} \\
(0.046)\end{array}$ & $\begin{array}{l}-1.258 \\
(0.365)\end{array}$ \\
\hline CapitalStringency $\left(\gamma_{3}\right)$ & $\begin{array}{l}-0.017 \\
(0.101)\end{array}$ & $\begin{array}{l}-0.016^{* *} \\
(0.040)\end{array}$ & $\begin{array}{l}2.771^{* * * *} \\
(0.008)\end{array}$ & $\begin{array}{l}0.217^{* * *} \\
(0.011)\end{array}$ & $\begin{array}{l}2.539^{* * *} \\
(0.010)\end{array}$ \\
\hline OfficialSupervisory $\left(\gamma_{4}\right)$ & $\begin{array}{l}0.006 \\
(0.473)\end{array}$ & $\begin{array}{l}0.017^{* * *} \\
(0.008)\end{array}$ & $\begin{array}{l}2.521^{* * *} \\
(0.027)\end{array}$ & $\begin{array}{l}0.034 \\
(0.567)\end{array}$ & $\begin{array}{l}2.481^{* * *} \\
(0.024)\end{array}$ \\
\hline Intercept $\left(\alpha_{0}\right)$ & $\begin{array}{l}2.063^{* 3 *} \\
(0.000)\end{array}$ & $\begin{array}{l}0.604^{* *} \\
(0.000)\end{array}$ & $\begin{array}{l}45.472^{*} \\
(0.012)\end{array}$ & $\begin{array}{l}3.082^{*} \\
(0.012)\end{array}$ & $\begin{array}{l}42.232^{* *} \\
(0.014)\end{array}$ \\
\hline Ownership type & Yes & Yes & Yes & Yes & Yes \\
\hline $\begin{array}{l}\text { Number of observations } \\
\text { Number of banks } \\
\text { R-square (overall) }\end{array}$ & $\begin{array}{l}4,451 \\
788 \\
0.396\end{array}$ & $\begin{array}{l}4,451 \\
788 \\
0.207\end{array}$ & $\begin{array}{l}4,451 \\
788 \\
0.076\end{array}$ & $\begin{array}{l}4,451 \\
788 \\
0.121\end{array}$ & $\begin{array}{l}4,451 \\
788 \\
0.078\end{array}$ \\
\hline 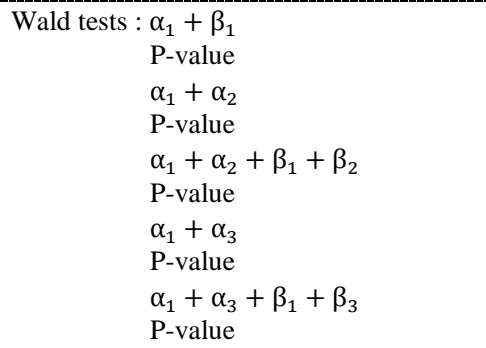 & $\begin{array}{l}-0.006^{* * *} \\
(0.000) \\
0.001 \\
(0.149) \\
0.003^{* *} \\
(0.025) \\
-0.001^{*} \\
(0.096) \\
-0.003^{* *} \\
(0.019)\end{array}$ & $\begin{array}{l}0.002^{* * *} \\
(0.001) \\
-0.000 \\
(0.860) \\
-0.001^{*} \\
(0.072) \\
0.001 \\
(0.139) \\
0.002^{* *} \\
(0.025)\end{array}$ & $\begin{array}{l}-0.373^{* * *} \\
(0.001) \\
-0.181^{* *} \\
(0.037) \\
-0.136 \\
(0.205) \\
-0.201^{* * *} \\
(0.001) \\
-0.252^{* * *} \\
(0.000)\end{array}$ & $\begin{array}{l}-0.017^{* *} \\
(0.048) \\
0.002 \\
(0.505) \\
0.007^{* *} \\
(0.046) \\
-0.004 \\
(0.696) \\
-0.008^{*} \\
(0.088)\end{array}$ & $\begin{array}{l}-0.356^{* * *} \\
(0.001) \\
-0.183^{* *} \\
(0.033) \\
-0.143 \\
(0.193) \\
-0.197^{* * *} \\
(0.000) \\
-0.244^{* * *} \\
(0.000)\end{array}$ \\
\hline
\end{tabular}

Variables definition: ROA=3-year rolling-window mean of the return on average assets; SDROA=3-year rolling-window standard deviation of the return on average assets; ZScore=measure of bank default risk; Z1Score=measure of bank asset risk; Z2Score=measure of leverage risk; ExcessControl=difference between control and cash-flow rights; Family=dummy equal to one if the largest controlling owner is an individual, a family or a manager, and zero otherwise; Crisis=dummy equal to one if the year is 2007 or 2008 , and zero otherwise; PostCrisis=dummy equal to one if the year is 2009 or 2010 , and zero otherwise; $\log ($ Assets)=natural logarithm of total assets; Equity=ratio of total equity to total assets; Deposits=ratio of customer deposits to total assets; Loans=ratio of net loans to total assets; NNII=ratio of net non-interest income to net operating income; CostIncomeRatio=cost to income ratio; Listed=dummy equal to one if the bank is publicly listed, and zero otherwise; Rescue=dummy equal to one if the bank was rescued during the 2007-2008 financial crisis, and zero otherwise; GDPGrowth=real GDP growth rate; RightsProtection=anti-director index of the level of shareholder protection; CapitalStringency=regulatory capital stringency index; OfficialSupervisory=index of official supervisory power; Ownership type=set of dummies representing the type of the largest ultimate owner (Widely is the benchmark group). P-values based on robust standard errors are shown in parentheses. ${ }^{* * *},{ }^{* *}$ and ${ }^{*}$ indicate significance respectively at the $1 \%, 5 \%$ and $10 \%$ levels. 
Table 8: Excess control rights, bank profitability and risk (2002-2010, GLS): effect of shareholder protection rights

$Y_{\text {it }}=\left[\alpha_{1}+\alpha_{2}\right.$ Crisis $+\alpha_{3}$ PostCrisis $+\left(\beta_{1}+\beta_{2}\right.$ Crisis $+\beta_{3}$ PostCrisis $)$ ShareRight $]$ ExcessControl $_{i t}+\left(\delta^{\prime}+\right.$ $\tau^{\prime}$ ShareRight)TDummy $+\varphi^{\prime} \mathrm{X}+\gamma^{\prime} \mathrm{Z}+\alpha_{0}+\varepsilon_{\mathrm{it}}$

\begin{tabular}{|c|c|c|c|c|c|}
\hline Dependent variable (Y) & ROA & SDROA & ZScore & Z1Score & Z2Score \\
\hline \multirow[t]{2}{*}{ ExcessControl $\left(\alpha_{1}\right)$} & $-0.002^{* *}$ & $0.001^{*}$ & $-0.237^{* * *}$ & $-0.008^{*}$ & $-0.229^{* * *}$ \\
\hline & $(0.041)$ & $(0.082)$ & $(0.000)$ & $(0.066)$ & $(0.000)$ \\
\hline \multirow[t]{2}{*}{ ShareRight $\times$ ExcessControl $\left(\beta_{1}\right)$} & $-0.003^{* *}$ & 0.000 & $-0.148^{*}$ & $-0.009^{*}$ & $-0.139^{*}$ \\
\hline & $(0.043)$ & $(0.434)$ & $(0.058)$ & $(0.058)$ & $(0.059)$ \\
\hline \multirow[t]{2}{*}{ Crisis $\times$ ExcessControl $\left(\alpha_{2}\right)$} & $0.003^{*}$ & $-0.001^{* * *}$ & $0.130^{* * *}$ & $0.002^{*}$ & $0.128^{* * *}$ \\
\hline & $(0.064)$ & $(0.013)$ & $(0.015)$ & $(0.054)$ & $(0.015)$ \\
\hline \multirow[t]{2}{*}{ Crisis $\times$ ShareRight $\times$ ExcessControl $\left(\beta_{2}\right)$} & $0.004^{* *_{*}^{* *}}$ & $-0.001^{\text {** }}$ & $0.168^{* *}$ & $0.025^{* *}$ & $0.143^{* *}$ \\
\hline & $(0.005)$ & $(0.016)$ & $(0.010)$ & $(0.029)$ & $(0.011)$ \\
\hline \multirow[t]{2}{*}{ PostCrisis $\times$ ExcessControl $\left(\alpha_{3}\right)$} & 0.001 & 0.000 & 0.025 & 0.002 & 0.023 \\
\hline & $(0.680)$ & $(0.515)$ & $(0.217)$ & $(0.725)$ & $(0.190)$ \\
\hline \multirow[t]{2}{*}{ PostCrisis $\times$ ShareRight $\times$ ExcessControl $\left(\beta_{3}\right)$} & 0.001 & 0.001 & 0.056 & 0.005 & 0.051 \\
\hline & $(0.174)$ & $(0.544)$ & $(0.580)$ & $(0.572)$ & $(0.510)$ \\
\hline \multirow[t]{2}{*}{ Crisis $\left(\delta_{1}\right)$} & $-0.210^{* * *}$ & 0.016 & $-6.137^{*}$ & $-0.879^{* *-}$ & $-5.322^{*}$ \\
\hline & $(0.000)$ & $(0.401)$ & $(0.082)$ & $(0.019)$ & $(0.094)$ \\
\hline \multirow[t]{2}{*}{ PostCrisis $\left(\delta_{2}\right)$} & $-0.422^{* * * *}$ & $0.041^{* *}$ & $-4.831^{*}$ & $-1.178^{* * * *}$ & -3.656 \\
\hline & $(0.000)$ & $(0.022)$ & $(0.066)$ & $(0.000)$ & $(0.344)$ \\
\hline \multirow{2}{*}{ Crisis $\times$ ShareRight $\left(\tau_{1}\right)$} & $0.068^{*}$ & 0.022 & -5.761 & $-0.772^{*}$ & -5.037 \\
\hline & $(0.091)$ & $(0.385)$ & $(0.264)$ & $(0.056)$ & $(0.298)$ \\
\hline \multirow[t]{2}{*}{ PostCrisis $\times$ ShareRight $\left(\tau_{2}\right)$} & $0.263^{* * *}$ & 0.001 & -4.262 & 0.394 & -4.656 \\
\hline & (0.000) & (0.973) & $(0.328)$ & $(0.255)$ & $(0.338)$ \\
\hline \multirow{2}{*}{$\log ($ Assets $)\left(\varphi_{1}\right)$} & $-0.099^{* * *}$ & $-0.056^{* * * *}$ & $-1.754^{* *}$ & $0.175^{* * *}$ & $-1.918^{* *}$ \\
\hline & $(0.000)$ & $(0.000)$ & $(0.026)$ & $(0.003)$ & $(0.011)$ \\
\hline \multirow[t]{2}{*}{ Equity $\left(\varphi_{2}\right)$} & $0.209^{* * *}$ & $0.065^{* * *}$ & $5.062^{* * * *}$ & -0.026 & $5.037^{* * * *}$ \\
\hline & $(0.000)$ & $(0.000)$ & $(0.003)$ & $(0.773)$ & $(0.002)$ \\
\hline \multirow[t]{2}{*}{ Deposits $\left(\varphi_{3}\right)$} & $0.002^{* * * *}$ & 0.000 & $0.110^{*}$ & $0.019^{* * * *}$ & $0.095^{*^{\prime}}$ \\
\hline & $(0.000)$ & $(0.961)$ & $(0.071)$ & $(0.000)$ & $(0.099)$ \\
\hline \multirow[t]{2}{*}{ Loans $\left(\varphi_{4}\right)$} & 0.001 & $-0.002^{* * * *}$ & $0.298^{* * * *}$ & $0.022^{* * *}$ & $0.274^{* *_{*}^{* * *}}$ \\
\hline & $(0.369)$ & $(0.002)$ & $(0.000)$ & $(0.000)$ & $(0.000)$ \\
\hline \multirow[t]{2}{*}{$\operatorname{NNII}\left(\varphi_{5}\right)$} & $0.003^{\text {*** }}$ & 0.000 & $-0.096^{* * *}$ & 0.004 & $-0.096^{* * * *}$ \\
\hline & $(0.000)$ & $(0.282)$ & $(0.015)$ & $(0.193)$ & $(0.009)$ \\
\hline \multirow[t]{2}{*}{ CostIncomeRatio $\left(\varphi_{6}\right)$} & $-0.013^{* * * *}$ & $0.001^{* * * *}$ & $-0.242^{* * * *}$ & $-0.045^{* * * *}$ & $-0.199^{\text {**** }}$ \\
\hline & $(0.000)$ & $(0.004)$ & $(0.000)$ & $(0.000)$ & $(0.000)$ \\
\hline Listed $\left(\varphi_{7}\right)$ & $0.171^{* * *}$ & $0.052^{*}$ & $-19.878^{* * *}$ & -0.397 & $-19.439^{* * * *}$ \\
\hline & $(0.000)$ & $(0.091)$ & $(0.000)$ & $(0.279)$ & $(0.000)$ \\
\hline Rescue $\left(\varphi_{8}\right)$ & -0.008 & -0.007 & -2.631 & -0.305 & -2.278 \\
\hline (4) & $(0.877)$ & (0.874) & (0.609) & (0.608) & $(0.621)$ \\
\hline GDPGrowth $\left(\gamma_{1}\right)$ & $0.012^{* * *}$ & $-0.005^{* * *}$ & $1.040^{* * * *}$ & $0.085^{\text {*** }}$ & $0.962^{* * * 4}$ \\
\hline & $(0.000)$ & $(0.007)$ & $(0.003)$ & $(0.002)$ & $(0.003)$ \\
\hline ShareRight $\left(\gamma_{2}\right)$ & $-0.231^{* * *}$ & $-0.073^{* *}$ & -2.371 & -0.303 & -2.069 \\
\hline & $(0.000)$ & $(0.015)$ & $(0.632)$ & $(0.352)$ & $(0.661)$ \\
\hline CapitalStringency $\left(\gamma_{3}\right)$ & $-0.026^{* *}$ & $-0.017^{* *}$ & $2.503^{* * *}$ & $0.145^{*}$ & $2.348^{* * *}$ \\
\hline & $(0.013)$ & $(0.043)$ & $(0.016)$ & $(0.083)$ & $(0.017)$ \\
\hline OfficialSupervisory $\left(\gamma_{4}\right)$ & 0.004 & $0.016^{* *}$ & $2.517^{* *}$ & 0.047 & $2.462^{* * *}$ \\
\hline & $(0.599)$ & $(0.015)$ & $(0.025)$ & $(0.431)$ & $(0.023)$ \\
\hline Intercept $\left(\alpha_{0}\right)$ & $2.347^{* * *}$ & $0.742^{* * *}$ & $43.709^{* *}$ & $2.829^{* *}$ & $40.811^{*}$ \\
\hline & $(0.000)$ & $(0.000)$ & $(0.010)$ & $(0.019)$ & $(0.012)$ \\
\hline Ownership type & Yes & Yes & Yes & Yes & Yes \\
\hline Number of observations & 4,451 & 4,451 & 4,451 & 4,451 & 4,451 \\
\hline Number of banks & 788 & 788 & 788 & 788 & 788 \\
\hline R-square (overall) & 0.413 & 0.204 & 0.075 & 0.122 & 0.077 \\
\hline Wald tests : $\alpha_{1}+\beta_{1}$ & $-0.005^{* * *}$ & $0.001^{* *}$ & $-0.385^{* * *}$ & $-0.017^{* * *}$ & $-0.366^{* * *}$ \\
\hline P-value & $(0.000)$ & $(0.011)$ & $(0.000)$ & $(0.000)$ & $(0.000)$ \\
\hline$\alpha_{1}+\alpha_{2}$ & 0.001 & -0.000 & $-0.197^{* *}$ & -0.006 & $-0.189^{* *}$ \\
\hline P-value & $(0.479)$ & $(0.340)$ & $(0.048)$ & $(0.278)$ & $(0.049)$ \\
\hline$\alpha_{1}+\alpha_{2}+\beta_{1}+\beta_{2}$ & $0.002^{* *}$ & $-0.001^{* *}$ & -0.086 & $0.010^{* * *}$ & -0.095 \\
\hline P-value & $(0.028)$ & $(0.048)$ & $(0.391)$ & $(0.032)$ & $(0.307)$ \\
\hline$\alpha_{1}+\alpha_{3}$ & -0.001 & 0.001 & $-0.212^{* * * *}$ & -0.006 & $-0.206^{* * * *}$ \\
\hline P-value & $(0.170)$ & $(0.153)$ & $(0.000)$ & $(0.367)$ & $(0.000)$ \\
\hline$\alpha_{1}+\beta_{1}+\alpha_{1}+\alpha_{3}$ & $-0.003^{* *}$ & $0.002^{*}$ & $-0.306^{* * *}$ & $-0.010^{* *}$ & $-0.294^{* * *}$ \\
\hline P-value & $(0.017)$ & $(0.082)$ & $(0.000)$ & $(0.032)$ & $(0.000)$ \\
\hline
\end{tabular}

Variables definition: ROA=3-year rolling-window mean of the return on assets; SDROA=3-year rolling-window standard deviation of the return on average assets; ZScore=measure of bank default risk; Z1Score=measure of bank asset risk; Z2Score=measure of leverage risk; ExcessControl=difference between control and cash-flow rights; ShareRight=dummy equal to one if the anti-director index is lower than the median value, and zero otherwise; Crisis=dummy equal to one if the year is 2007 or 2008, and zero otherwise; PostCrisis=dummy equal to one if the year is 2009 or 2010, and zero otherwise; $\log$ (Assets)=natural logarithm of total assets; Equity=ratio of total equity to total assets; Deposits=ratio of customer deposits to total assets; Loans=ratio of net loans to total assets; NNII=ratio of net non-interest income to net operating income; CostIncomeRatio=cost to income ratio; Listed=dummy equal to one if the bank is publicly listed, and zero otherwise; Rescue=dummy equal to one if the bank was rescued during the 2007-2008 financial crisis, and zero otherwise; GDPGrowth=real GDP growth rate; CapitalStringency=index of regulatory restrictions on bank capital; OfficialSupervisory=index of official supervisory power; Ownership type=set of dummy variables representing the type of the largest ultimate owner (Widely is the benchmark group). P-values based on robust standard errors are shown in parentheses. ${ }^{* * *},{ }^{* *}$ and ${ }^{*}$ indicate significance respectively at the $1 \%, 5 \%$ and $10 \%$ levels. 
Table 9: Excess control rights and the change in bank profitability (OLS estimation)

$Y_{i}=\alpha_{1}$ ExcessControl $_{i}+\varphi^{\prime} X_{i}+\gamma^{\prime} Z_{c}+\alpha_{0}+\varepsilon_{i}$,

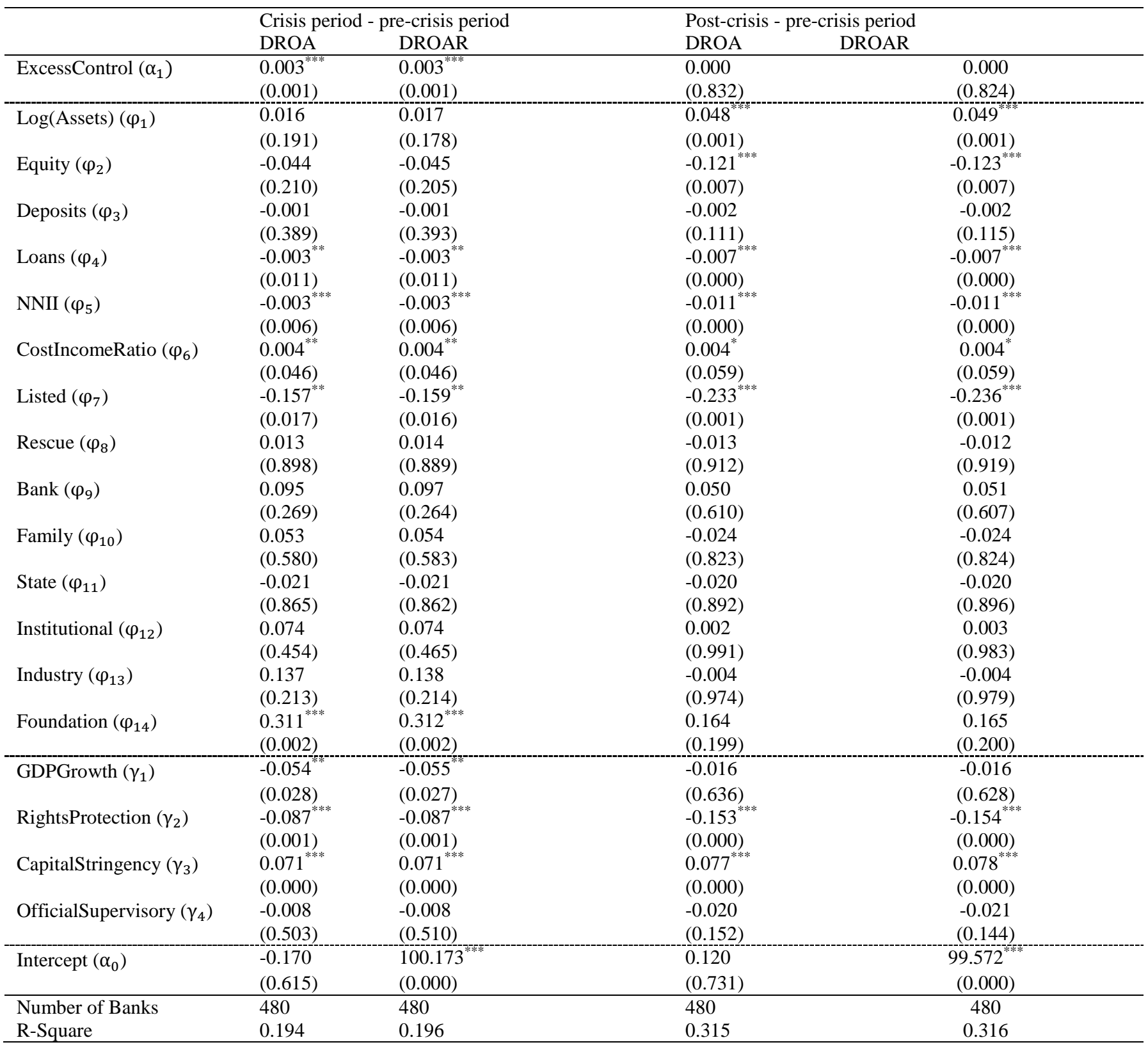

Variables definition: $\mathrm{DROA}=$ change in individual bank profitability defined as DROA $=\mathrm{ROA}-\overline{\mathrm{ROA}}$ where ROA is either the crisis or post-crisis bank's return on average assets and $\overline{\mathrm{ROA}}$ is the pre-crisis bank's return on average assets; DROAR=change in industry-adjusted profitability defined as DROAR $=\frac{100-\left(\overline{\mathrm{ROA}}-\overline{\mathrm{ROA}} \mathrm{A}_{\text {industry }}\right)}{100-\left(\mathrm{ROA}-\mathrm{ROA}^{\text {industry }}\right)}$ where ROA $\mathrm{A}^{\text {industry }}$ is either the crisis or post-crisis industry's return on average assets and $\overline{\mathrm{ROA}^{\text {industry }}}$ is the pre-crisis industry's return on average assets; ExcessControl=difference between control and cash-flow rights; Crisis=dummy equal to one if the year is 2007 or 2008, and zero otherwise; PostCrisis=dummy equal to one if the year is 2009 or 2010 , and zero otherwise; $\log ($ Assets $)=$ natural logarithm of total assets; Equity=ratio of total equity to total assets; Deposits=ratio of customer deposits to total assets; Loans=ratio of net loans to total assets; NNII=ratio of net non-interest income to net operating income; CostIncomeRatio=cost to income ratio; Listed=dummy equal to one if the bank is publicly listed, and zero otherwise; Rescue=dummy equal to one if the bank was rescued during the 2007-2008 financial crisis, and zero otherwise; Bank-Foundation is a set of dummy variables representing the type of the largest ultimate owner (Widely is the benchmark group); GDPGrowth=real GDP growth rate; RightsProtection=anti-director index of the level of shareholder protection; CapitalStringency=regulatory capital stringency index; OfficialSupervisory=index of official supervisory power. P-values based on robust standard errors are shown in parentheses. ${ }^{* * *},{ }^{* *}$ and ${ }^{*}$ indicate significance respectively at the $1 \%, 5 \%$ and $10 \%$ levels. 
Table 10: Nonlinearity in the relationship between excess control rights and bank profitability and risk (2002-2010, GLS)

$$
\begin{aligned}
Y_{i t} & =\sum_{\substack{j=1\\
}}^{4} \alpha_{j} \text { ExcessControlQ }_{j}+\text { Crisis } \sum_{j=1}^{4} \beta_{j} \text { ExcessControlQ }_{j}+\text { PostCrisis } \sum_{j=1}^{4} \tau_{j} \text { ExcessControl }_{j}+\delta^{\prime} \mathrm{TDummy}^{\prime} \\
& +\varphi^{\prime} \mathrm{X}+\gamma^{\prime} \mathrm{Z}+\alpha_{0}+\varepsilon_{\mathrm{it}}
\end{aligned}
$$

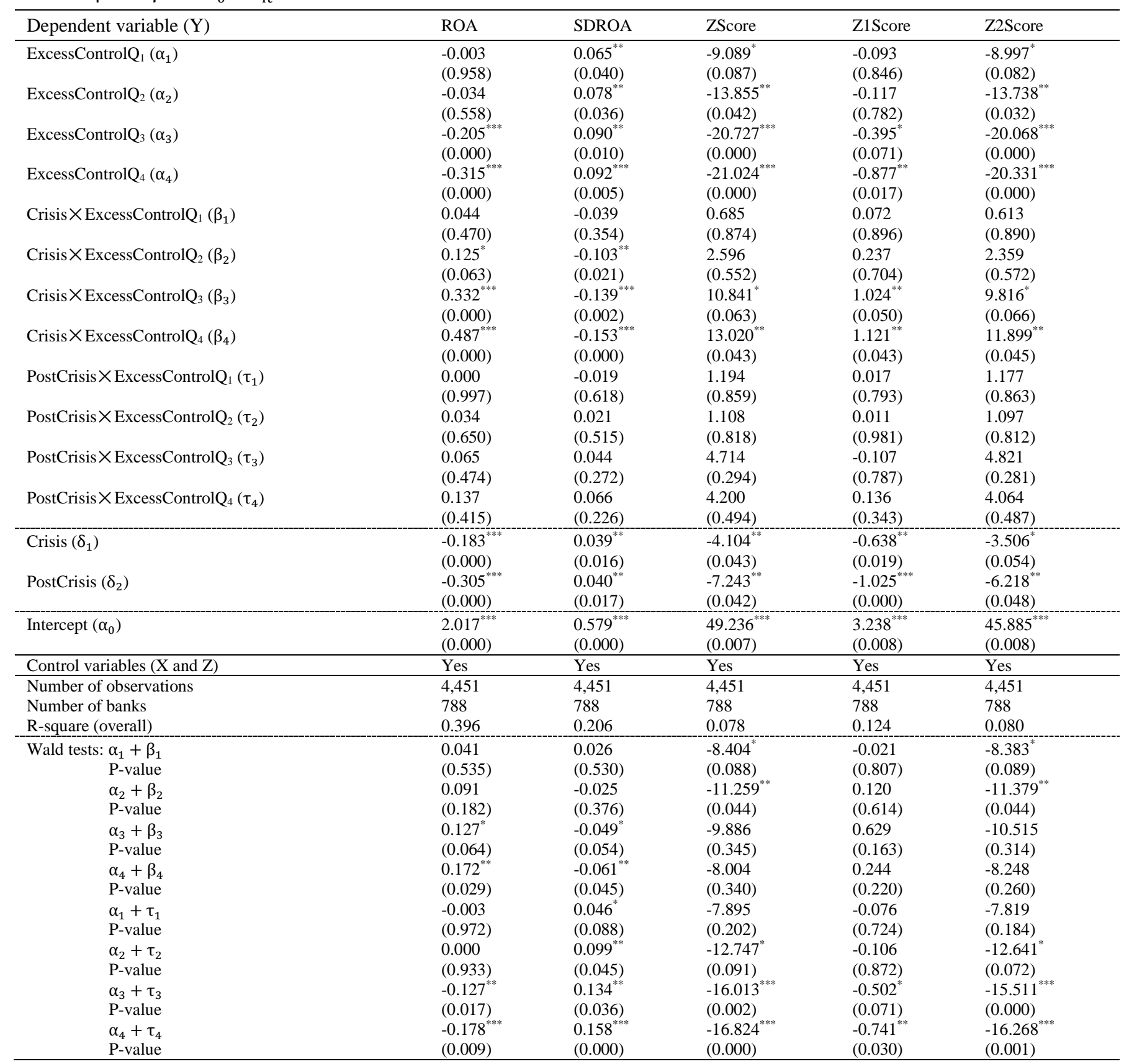

Variables definition: ROA=3-year rolling-window mean of the return on average assets; SDROA=3-year rolling-window standard deviation of the return on average assets; ZScore=measure of bank default risk; Z1Score=measure of bank asset risk; Z2Score $=$ measure of leverage risk; ExcessControlQ $\mathrm{Q}_{1}=$ dummy equal to one if $0<$ ExcessControl $<=\mathrm{Q}_{1}$, and zero otherwise; ExcessControlQ $\mathrm{Q}_{2}=\mathrm{dummy}_{\mathrm{m}}$ equal to one if $\mathrm{Q}_{1}<$ ExcessControl $<=\mathrm{Q}_{2}$, and zero otherwise; ExcessControl $\mathrm{Q}_{3}=$ dummy equal to one if $\mathrm{Q}_{2}<$ ExcessControl $<=\mathrm{Q}_{3}$, and zero otherwise; ExcessControl $Q_{4}=$ dummy equal to one if ExcessControl $>Q_{3}$, and zero otherwise; $Q_{1}, Q_{2}, Q_{3}$ and $Q_{4}$ are respectively the first, second, third and fourth quartile of the variable ExcessControl when ExcessControl $>0$; ExcessControl=difference between control and cash-flow rights; Crisis=dummy equal to one if the year is 2007 or 2008, and zero otherwise; PostCrisis=dummy equal to one if the year is 2009 or 2010 , and zero otherwise. P-values based on robust standard errors are shown in parentheses. ${ }^{* * *},{ }^{* *}$ and ${ }^{*}$ indicate significance respectively at the $1 \%, 5 \%$ and $10 \%$ levels. 
Table A1: Correlations among the main explanatory variables used in the regressions

\begin{tabular}{|c|c|c|c|c|c|c|c|c|c|c|c|c|c|c|c|}
\hline & (1) & (2) & (3) & (4) & (5) & (6) & (7) & (8) & (9) & (10) & (11) & (12) & (13) & (14) & (15) \\
\hline ExcessControl (1) & 1 & & & & & & & & & & & & & & \\
\hline Log(Assets) (2) & 0.008 & 1 & & & & & & & & & & & & & \\
\hline Equity (3) & -0.024 & -0.527 & 1 & & & & & & & & & & & & \\
\hline Deposits (4) & -0.077 & -0.272 & -0.046 & 1 & & & & & & & & & & & \\
\hline Loans (5) & -0.049 & 0.072 & -0.118 & -0.003 & 1 & & & & & & & & & & \\
\hline NNII (6) & 0.020 & -0.122 & 0.140 & 0.048 & -0.291 & 1 & & & & & & & & & \\
\hline CostIncomeRatio (7) & -0.050 & -0.209 & 0.061 & 0.168 & -0.062 & 0.159 & 1 & & & & & & & & \\
\hline Listed (8) & -0.166 & 0.301 & -0.089 & 0.017 & 0.162 & -0.070 & -0.059 & 1 & & & & & & & \\
\hline Rescue (9) & -0.008 & 0.225 & -0.082 & -0.077 & 0.023 & -0.053 & -0.026 & 0.140 & 1 & & & & & & \\
\hline Crisis (10) & 0.000 & 0.022 & -0.023 & -0.003 & 0.023 & -0.042 & -0.010 & -0.015 & 0.101 & 1 & & & & & \\
\hline PostCrisis (11) & 0.006 & 0.069 & -0.024 & 0.035 & -0.006 & 0.023 & 0.002 & -0.016 & 0.088 & -0.300 & 1 & & & & \\
\hline GDPGrowth (12) & 0.030 & -0.026 & 0.007 & -0.015 & -0.077 & 0.055 & -0.035 & -0.018 & -0.052 & 0.083 & -0.542 & 1 & & & \\
\hline RightsProtection (13) & -0.092 & 0.032 & 0.143 & -0.047 & 0.124 & -0.136 & -0.055 & 0.097 & -0.034 & -0.007 & -0.012 & -0.053 & 1 & & \\
\hline CapitalStringency (14) & 0.060 & 0.009 & 0.023 & -0.081 & -0.134 & 0.095 & -0.027 & -0.213 & -0.070 & 0.005 & 0.004 & 0.050 & 0.254 & 1 & \\
\hline OfficialSupervisory (15) & -0.001 & -0.130 & 0.121 & -0.026 & -0.163 & 0.166 & 0.024 & 0.010 & 0.044 & -0.010 & 0.017 & 0.123 & -0.168 & -0.068 & 1 \\
\hline
\end{tabular}

Variables definition: ExcessControl=difference between control and cash-flow rights; Log(Assets)=natural logarithm of total assets; Equity=ratio of total equity to total assets; Deposits=ratio of total customer deposits to total assets; Loans=ratio of net loans to total assets; $\mathrm{NNII=ratio} \mathrm{of} \mathrm{net} \mathrm{non-interest} \mathrm{income} \mathrm{to} \mathrm{net} \mathrm{operating} \mathrm{income;} \mathrm{CostIncomeRatio=cost} \mathrm{to} \mathrm{income} \mathrm{ratio;} \mathrm{Listed=dummy} \mathrm{equal} \mathrm{to} \mathrm{one} \mathrm{if} \mathrm{the}$ bank is publicly listed, and zero otherwise; Rescue=dummy equal to one if the bank was rescued during the 2007-2008 financial crisis, and zero otherwise; Crisis=dummy equal to one if the year is 2007 or 2008, and zero otherwise; PostCrisis=dummy equal to one if the year is 2009 or 2010, and zero otherwise; GDPGrowth=real GDP growth rate; RightsProtection=anti-director index of the level of shareholder protection; CapitalStringency=regulatory capital stringency index; OfficialSupervisory=index of official supervisory power. 
Table A2: Excess control rights, bank profitability and risk (2002-2010, GLS): use of country dummies

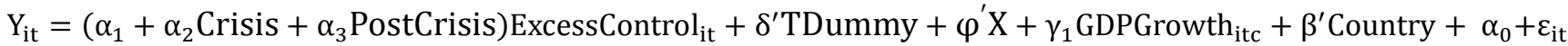

\begin{tabular}{|c|c|c|c|c|c|}
\hline Dependent variable $(\mathrm{Y})$ & ROA & SDROA & ZScore & Z1Score & Z2Score \\
\hline ExcessControl $\left(\alpha_{1}\right)$ & $\begin{array}{l}-0.004^{* * * *} \\
(0.000)\end{array}$ & $\begin{array}{l}0.001^{* * * *} \\
(0.008)\end{array}$ & $\begin{array}{l}-0.260^{* * * *} \\
(0.000)\end{array}$ & $\begin{array}{l}-0.011^{* *} \\
(0.037)\end{array}$ & $\begin{array}{l}-0.249^{* * *} \\
(0.000)\end{array}$ \\
\hline Crisis $\times$ ExcessControl $\left(\alpha_{2}\right)$ & $\begin{array}{l}0.006^{* * * *} \\
(0.000)\end{array}$ & $\begin{array}{l}-0.002^{* * *} \\
(0.000)\end{array}$ & $\begin{array}{l}0.130^{* * *} \\
(0.047)\end{array}$ & $\begin{array}{l}0.007^{* *} \\
(0.041)\end{array}$ & $\begin{array}{l}0.123^{*} \\
(0.052)\end{array}$ \\
\hline PostCrisis $\times$ ExcessControl $\left(\alpha_{3}\right)$ & $\begin{array}{l}0.001 \\
(0.108)\end{array}$ & $\begin{array}{l}0.000 \\
(0.827)\end{array}$ & $\begin{array}{l}0.049 \\
(0.326)\end{array}$ & $\begin{array}{l}0.004 \\
(0.405)\end{array}$ & $\begin{array}{l}0.046 \\
(0.322)\end{array}$ \\
\hline Crisis $\left(\delta_{1}\right)$ & $\begin{array}{l}-0.183^{3 * *} \\
(0.000)\end{array}$ & $\begin{array}{l}0.027^{*} \\
(0.068)\end{array}$ & $\begin{array}{l}-4.535^{* k} \\
(0.049)\end{array}$ & $\begin{array}{l}-0.474^{*} \\
(0.065)\end{array}$ & $\begin{array}{l}4.061^{*} \\
(0.052)\end{array}$ \\
\hline PostCrisis $\left(\delta_{2}\right)$ & $\begin{array}{l}-0.303^{* * *} \\
(0.000)\end{array}$ & $\begin{array}{l}0.042^{* * * *} \\
(0.006)\end{array}$ & $\begin{array}{l}-7.011^{* *} \\
(0.036)\end{array}$ & $\begin{array}{l}-1.099^{* * * *} \\
(0.000)\end{array}$ & $\begin{array}{l}-5.912^{* *} \\
(0.039)\end{array}$ \\
\hline $\log ($ Assets $)\left(\varphi_{1}\right)$ & $\begin{array}{l}-0.088^{* * *} \\
(0.000)\end{array}$ & $\begin{array}{l}-0.054^{* * 3} \\
(0.000)\end{array}$ & $\begin{array}{l}-1.624^{* *} \\
(0.047)\end{array}$ & $\begin{array}{l}0.193^{* * *} \\
(0.001)\end{array}$ & $\begin{array}{l}-1.803^{* *} \\
(0.020)\end{array}$ \\
\hline Equity $\left(\varphi_{2}\right)$ & $\begin{array}{l}0.216^{* * * *} \\
(0.000)\end{array}$ & $\begin{array}{l}0.062^{* * * *} \\
(0.000)\end{array}$ & $\begin{array}{l}4.635^{* * * *} \\
(0.008)\end{array}$ & $\begin{array}{l}0.002 \\
(0.986)\end{array}$ & $\begin{array}{l}4.599^{* * * * *} \\
(0.007)\end{array}$ \\
\hline Deposits $\left(\varphi_{3}\right)$ & $\begin{array}{l}0.002^{* * * *} \\
(0.000)\end{array}$ & $\begin{array}{l}-0.000 \\
(0.995)\end{array}$ & $\begin{array}{l}0.115^{*} \\
(0.058)\end{array}$ & $\begin{array}{l}0.020^{* * * * *} \\
(0.000)\end{array}$ & $\begin{array}{l}0.098^{*} \\
(0.085)\end{array}$ \\
\hline Loans $\left(\varphi_{4}\right)$ & $\begin{array}{l}0.000 \\
(0.553)\end{array}$ & $\begin{array}{l}-0.002^{\text {**** }} \\
(0.001)\end{array}$ & $\begin{array}{l}0.272^{* * *} \\
(0.000)\end{array}$ & $\begin{array}{l}0.022^{* * * *} \\
(0.000)\end{array}$ & $\begin{array}{l}0.248^{* * * *} \\
(0.000)\end{array}$ \\
\hline $\operatorname{NNII}\left(\varphi_{5}\right)$ & $\begin{array}{l}0.002^{* * * *} \\
(0.000)\end{array}$ & $\begin{array}{l}0.000 \\
(0.343)\end{array}$ & $\begin{array}{l}-0.125^{* * * *} \\
(0.003)\end{array}$ & $\begin{array}{l}0.001 \\
(0.721)\end{array}$ & $\begin{array}{l}-0.122^{* * * *} \\
(0.002)\end{array}$ \\
\hline CostIncomeRatio $\left(\varphi_{6}\right)$ & $\begin{array}{l}-0.013^{* * *} \\
(0.000)\end{array}$ & $\begin{array}{l}0.001^{* * * *} \\
(0.005)\end{array}$ & $\begin{array}{l}-0.270^{* * * *} \\
(0.000)\end{array}$ & $\begin{array}{l}-0.048^{* * * *} \\
(0.000)\end{array}$ & $\begin{array}{l}-0.225^{* * * *} \\
(0.000)\end{array}$ \\
\hline Listed $\left(\varphi_{7}\right)$ & $\begin{array}{l}0.154^{* * * *} \\
(0.001)\end{array}$ & $\begin{array}{l}0.037 \\
(0.284)\end{array}$ & $\begin{array}{l}-11.175^{* *} \\
(0.014)\end{array}$ & $\begin{array}{l}0.271 \\
(0.500)\end{array}$ & $\begin{array}{l}-11.443^{* * * *} \\
(0.007)\end{array}$ \\
\hline Rescue $\left(\varphi_{8}\right)$ & $\begin{array}{l}0.038 \\
(0.472)\end{array}$ & $\begin{array}{l}-0.012 \\
(0.772)\end{array}$ & $\begin{array}{l}-1.958 \\
(0.715)\end{array}$ & $\begin{array}{l}-0.211 \\
(0.729)\end{array}$ & $\begin{array}{l}-1.708 \\
(0.723)\end{array}$ \\
\hline $\operatorname{Bank}\left(\varphi_{9}\right)$ & $\begin{array}{l}0.045 \\
(0.269)\end{array}$ & $\begin{array}{l}0.014 \\
(0.645)\end{array}$ & $\begin{array}{l}-5.963 \\
(0.295)\end{array}$ & $\begin{array}{l}-0.092 \\
(0.812)\end{array}$ & $\begin{array}{l}-5.773 \\
(0.286)\end{array}$ \\
\hline Family $\left(\varphi_{10}\right)$ & $\begin{array}{l}0.050 \\
(0.250)\end{array}$ & $\begin{array}{l}0.023 \\
(0.439)\end{array}$ & $\begin{array}{l}-2.961 \\
(0.612)\end{array}$ & $\begin{array}{l}0.283 \\
(0.497)\end{array}$ & $\begin{array}{l}-3.047 \\
(0.580)\end{array}$ \\
\hline State $\left(\varphi_{11}\right)$ & $\begin{array}{l}0.046 \\
(0.466)\end{array}$ & $\begin{array}{l}0.009 \\
(0.839)\end{array}$ & $\begin{array}{l}-1.801 \\
(0.799)\end{array}$ & $\begin{array}{l}-0.476 \\
(0.336)\end{array}$ & $\begin{array}{l}-1.168 \\
(0.862)\end{array}$ \\
\hline Institutional $\left(\varphi_{12}\right)$ & $\begin{array}{l}0.024 \\
(0.625)\end{array}$ & $\begin{array}{l}0.014 \\
(0.692)\end{array}$ & $\begin{array}{l}-3.807 \\
(0.506)\end{array}$ & $\begin{array}{l}-0.189 \\
(0.672)\end{array}$ & $\begin{array}{l}-3.488 \\
(0.515)\end{array}$ \\
\hline Industry $\left(\varphi_{13}\right)$ & $\begin{array}{l}0.016 \\
(0.779)\end{array}$ & $\begin{array}{l}0.073 \\
(0.122)\end{array}$ & $\begin{array}{l}-5.882 \\
(0.406)\end{array}$ & $\begin{array}{l}-0.038 \\
(0.937)\end{array}$ & $\begin{array}{l}-5.790 \\
(0.386)\end{array}$ \\
\hline Foundation $\left(\varphi_{14}\right)$ & $\begin{array}{l}0.038 \\
(0.575)\end{array}$ & $\begin{array}{l}-0.062 \\
(0.133)\end{array}$ & $\begin{array}{l}8.939 \\
(0.368)\end{array}$ & $\begin{array}{l}0.047 \\
(0.943)\end{array}$ & $\begin{array}{l}8.976 \\
(0.337)\end{array}$ \\
\hline $\operatorname{GDPG}\left(\gamma_{1}\right)$ & $\begin{array}{l}0.013^{\text {*** }} \\
(0.000)\end{array}$ & $\begin{array}{l}-0.005^{* *} \\
(0.011)\end{array}$ & $\begin{array}{l}1.036 \\
(0.003)\end{array}$ & $\begin{array}{l}0.066^{* * *} \\
(0.020)\end{array}$ & $\begin{array}{l}0.969^{* * *} \\
(0.003)\end{array}$ \\
\hline Intercept $\left(\alpha_{0}\right)$ & $\begin{array}{l}2.112^{* 3} \\
(0.000)\end{array}$ & $\begin{array}{l}0.756^{*} \\
(0.000)\end{array}$ & $\begin{array}{l}96.117^{*} \\
(0.000)\end{array}$ & $\begin{array}{l}5.996^{* *} \\
(0.000)\end{array}$ & $\begin{array}{l}89.921^{*} \\
(0.000)\end{array}$ \\
\hline Country dummies & Yes & Yes & Yes & Yes & Yes \\
\hline Number of observations & 4,451 & 4,451 & 4,451 & 4,451 & 4,451 \\
\hline Number of Banks & 788 & 788 & 788 & 788 & 788 \\
\hline R-Square (overall) & 0.424 & 0.209 & 0.098 & 0.153 & 0.099 \\
\hline 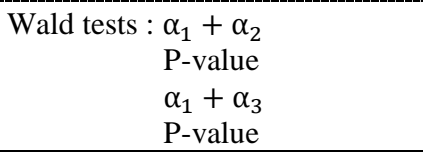 & $\begin{array}{l}0.002^{* *} \\
(0.039) \\
-0.003^{* * *} \\
(0.000) \\
\end{array}$ & $\begin{array}{l}-0.001 \\
(0.124) \\
0.001 * * \\
(0.038) \\
\end{array}$ & $\begin{array}{l}-0.130 \\
(0.103) \\
-0.209^{* * *} \\
(0.000) \\
\end{array}$ & $\begin{array}{l}-0.004 \\
(0.317) \\
-0.007 \\
(0.297) \\
\end{array}$ & $\begin{array}{l}-0.127 \\
(0.126) \\
-0.204^{* * *} \\
(0.000)\end{array}$ \\
\hline
\end{tabular}

Variables definition: ROA=3-year rolling-window mean of the return on average assets; SDROA=3-year rolling-window standard deviation of the return on average assets; ZScore=measure of bank default risk; Z1Score=measure of bank asset risk; Z2Score $=$ measure of leverage risk; ExcessControl=difference between control and cash-flow rights; Crisis=dummy equal to one if the year is 2007 or 2008 , and zero otherwise; PostCrisis=dummy equal to one if the year is 2009 or 2010, and zero otherwise; $\log ($ Assets $)=$ natural logarithm of total assets; Equity=ratio of total equity to total assets; Deposits=ratio of customer deposits to total assets; Loans=ratio of net loans to total assets; NNII=ratio of net non-interest income to net operating income; CostIncomeRatio=cost to income ratio; Listed=dummy equal to one if the bank is publicly listed, and zero otherwise; Rescue=dummy equal to one if the bank was rescued during the 2007-2008 financial crisis, and zero otherwise; Bank-Foundation is a set of dummy variables representing the type of the largest ultimate owner (Widely is the benchmark group); GDPGrowth=real GDP growth rate. P-values based on robust standard errors are shown in parentheses. ${ }^{* * *},{ }^{* *}$ and ${ }^{*}$ indicate significance respectively at the $1 \%, 5 \%$ and $10 \%$ levels. 
Table A3: Excess control rights, bank profitability and risk (2002-2010, GLS): dependent variables computed on the basis of 2-year rolling-window

$\mathrm{Y}_{\mathrm{it}}=\left(\alpha_{1}+\alpha_{2}\right.$ Crisis $+\alpha_{3}$ PostCrisis $)$ Excess Control $_{\text {it }}+\delta^{\prime} \mathrm{TDummy}+\varphi^{\prime} \mathrm{X}+\gamma^{\prime} \mathrm{Z}+\alpha_{0}+\varepsilon_{\mathrm{it}}$

\begin{tabular}{|c|c|c|c|c|c|}
\hline Dependent variable (Y) & ROA & SDROA & ZScore & Z1Score & Z2Score \\
\hline ExcessControl $\left(\alpha_{1}\right)$ & $\begin{array}{l}-0.005^{* * * *} \\
(0.000)\end{array}$ & $\begin{array}{l}0.002^{* * * *} \\
(0.000)\end{array}$ & $\begin{array}{l}-1.198^{* * * *} \\
(0.000)\end{array}$ & $\begin{array}{l}-0.052^{* * * *} \\
(0.000)\end{array}$ & $\begin{array}{l}-1.145^{* * * *} \\
(0.000)\end{array}$ \\
\hline Crisis $\times$ ExcessControl $\left(\alpha_{2}\right)$ & $\begin{array}{l}0.007^{* * * *} \\
(0.000)\end{array}$ & $\begin{array}{l}-0.003^{\text {**** }} \\
(0.000)\end{array}$ & $\begin{array}{l}0.735^{* * * *} \\
(0.001)\end{array}$ & $\begin{array}{l}0.044^{* *} \\
(0.023)\end{array}$ & $\begin{array}{l}0.689^{* * * *} \\
(0.001)\end{array}$ \\
\hline PostCrisis $\times$ ExcessControl $\left(\alpha_{3}\right)$ & $\begin{array}{l}0.003^{*} \\
(0.099)\end{array}$ & $\begin{array}{l}-0.000 \\
(0.535)\end{array}$ & $\begin{array}{l}0.115 \\
(0.467)\end{array}$ & $\begin{array}{l}0.017 \\
(0.157)\end{array}$ & $\begin{array}{l}0.099 \\
(0.504)\end{array}$ \\
\hline Crisis $\left(\delta_{1}\right)$ & $\begin{array}{l}-0.178^{* * *} \\
(0.000)\end{array}$ & $\begin{array}{l}0.079^{* * * *} \\
(0.000)\end{array}$ & $\begin{array}{l}-7.509^{* *} \\
(0.014)\end{array}$ & $\begin{array}{l}-0.789^{* * *} \\
(0.036)\end{array}$ & $\begin{array}{l}-6.720^{* *} \\
(0.024)\end{array}$ \\
\hline PostCrisis $\left(\delta_{2}\right)$ & $\begin{array}{l}-0.282^{* * *} \\
(0.000)\end{array}$ & $\begin{array}{l}0.016 \\
(0.295)\end{array}$ & $\begin{array}{l}-5.409 \\
(0.531)\end{array}$ & $\begin{array}{l}-2.101^{* * * *} \\
(0.004)\end{array}$ & $\begin{array}{l}-3.308 \\
(0.663)\end{array}$ \\
\hline $\log ($ Assets $)\left(\varphi_{1}\right)$ & $\begin{array}{l}-0.101^{* * *} \\
(0.000)\end{array}$ & $\begin{array}{l}-0.046 \\
(0.000)\end{array}$ & $\begin{array}{l}-6.134^{* * * *} \\
(0.001)\end{array}$ & $\begin{array}{l}0.252^{* *} \\
(0.046)\end{array}$ & $\begin{array}{l}-6.368 \\
(0.000)\end{array}$ \\
\hline Equity $\left(\varphi_{2}\right)$ & $\begin{array}{l}0.229^{* * * *} \\
(0.000)\end{array}$ & $\begin{array}{l}0.077^{* * * *} \\
(0.000)\end{array}$ & $\begin{array}{l}7.253 \\
(0.128)\end{array}$ & $\begin{array}{l}-0.178 \\
(0.456)\end{array}$ & $\begin{array}{l}7.292 \\
(0.114)\end{array}$ \\
\hline Deposits $\left(\varphi_{3}\right)$ & $\begin{array}{l}0.002^{* * * *} \\
(0.000)\end{array}$ & $\begin{array}{l}-0.000 \\
(0.758)\end{array}$ & $\begin{array}{l}0.071 \\
(0.670)\end{array}$ & $\begin{array}{l}0.038^{* * * *} \\
(0.000)\end{array}$ & $\begin{array}{l}0.036 \\
(0.822)\end{array}$ \\
\hline Loans $\left(\varphi_{4}\right)$ & $\begin{array}{l}0.000 \\
(0.872)\end{array}$ & $\begin{array}{l}-0.001^{* * * *} \\
(0.000)\end{array}$ & $\begin{array}{l}0.863^{* * *} \\
(0.000)\end{array}$ & $\begin{array}{l}0.054^{* * * *} \\
(0.000)\end{array}$ & $\begin{array}{l}0.808^{* * * *} \\
(0.000)\end{array}$ \\
\hline $\mathrm{NNII}\left(\varphi_{5}\right)$ & $\begin{array}{l}0.002^{* * * *} \\
(0.000)\end{array}$ & $\begin{array}{l}0.001^{* *} \\
(0.011)\end{array}$ & $\begin{array}{l}-0.448^{* * *} \\
(0.000)\end{array}$ & $\begin{array}{l}0.006 \\
(0.471)\end{array}$ & $\begin{array}{l}-0.442^{* * *} \\
(0.000)\end{array}$ \\
\hline CostIncomeRatio $\left(\varphi_{6}\right)$ & $\begin{array}{l}-0.014^{* * *} \\
(0.000)\end{array}$ & $\begin{array}{l}0.001^{* * *} \\
(0.021)\end{array}$ & $\begin{array}{l}-0.540^{* * *} \\
(0.000)\end{array}$ & $\begin{array}{l}-0.119^{* * * *} \\
(0.000)\end{array}$ & $\begin{array}{l}-0.431^{* * * *} \\
(0.002)\end{array}$ \\
\hline Listed $\left(\varphi_{7}\right)$ & $\begin{array}{l}0.187^{* * * *} \\
(0.000)\end{array}$ & $\begin{array}{l}0.047^{* * *} \\
(0.011)\end{array}$ & $\begin{array}{l}-29.902^{* * *} \\
(0.039)\end{array}$ & $\begin{array}{l}0.256 \\
(0.763)\end{array}$ & $\begin{array}{l}-30.003^{* * *} \\
(0.031)\end{array}$ \\
\hline Rescue $\left(\varphi_{8}\right)$ & $\begin{array}{l}-0.008 \\
(0.866)\end{array}$ & $\begin{array}{l}0.018 \\
(0.611)\end{array}$ & $\begin{array}{l}-20.509 \\
(0.107)\end{array}$ & $\begin{array}{l}-1.918 \\
(0.201)\end{array}$ & $\begin{array}{l}-18.377 \\
(0.108)\end{array}$ \\
\hline $\operatorname{Bank}\left(\varphi_{9}\right)$ & $\begin{array}{l}0.059 \\
(0.147)\end{array}$ & $\begin{array}{l}-0.001 \\
(0.965)\end{array}$ & $\begin{array}{l}-23.408 \\
(0.178)\end{array}$ & $\begin{array}{l}-0.827 \\
(0.384)\end{array}$ & $\begin{array}{l}-22.126 \\
(0.184)\end{array}$ \\
\hline Family $\left(\varphi_{10}\right)$ & $\begin{array}{l}0.060 \\
(0.160)\end{array}$ & $\begin{array}{l}0.008 \\
(0.729)\end{array}$ & $\begin{array}{l}-12.595 \\
(0.493)\end{array}$ & $\begin{array}{l}0.299 \\
(0.769)\end{array}$ & $\begin{array}{l}-12.179 \\
(0.489)\end{array}$ \\
\hline State $\left(\varphi_{11}\right)$ & $\begin{array}{l}-0.065 \\
(0.281)\end{array}$ & $\begin{array}{l}-0.037 \\
(0.255)\end{array}$ & $\begin{array}{l}4.311 \\
(0.863)\end{array}$ & $\begin{array}{l}-0.810 \\
(0.541)\end{array}$ & $\begin{array}{l}5.657 \\
(0.813)\end{array}$ \\
\hline Institutional $\left(\varphi_{12}\right)$ & $\begin{array}{l}0.054 \\
(0.244)\end{array}$ & $\begin{array}{l}-0.011 \\
(0.660)\end{array}$ & $\begin{array}{l}-15.628 \\
(0.414)\end{array}$ & $\begin{array}{l}-0.920 \\
(0.405)\end{array}$ & $\begin{array}{l}-14.010 \\
(0.445)\end{array}$ \\
\hline Industry $\left(\varphi_{13}\right)$ & $\begin{array}{l}0.060 \\
(0.338)\end{array}$ & $\begin{array}{l}-0.020 \\
(0.434)\end{array}$ & $\begin{array}{l}1.942 \\
(0.928)\end{array}$ & $\begin{array}{l}0.825 \\
(0.510)\end{array}$ & $\begin{array}{l}1.827 \\
(0.929)\end{array}$ \\
\hline Foundation $\left(\varphi_{14}\right)$ & $\begin{array}{l}0.030 \\
(0.640)\end{array}$ & $\begin{array}{l}-0.039 \\
(0.219)\end{array}$ & $\begin{array}{l}6.093 \\
(0.826)\end{array}$ & $\begin{array}{l}-0.094 \\
(0.951)\end{array}$ & $\begin{array}{l}6.575 \\
(0.803)\end{array}$ \\
\hline GDPGrowth $\left(\gamma_{1}\right)$ & $\begin{array}{l}0.012^{* *} \\
(0.000)\end{array}$ & $\begin{array}{l}-0.005^{* *} \\
(0.037)\end{array}$ & $\begin{array}{l}3.900^{*} \\
(0.010)\end{array}$ & $\begin{array}{l}0.354^{*} \\
(0.001)\end{array}$ & $\begin{array}{l}3.561^{* *} \\
(0.012)\end{array}$ \\
\hline RightsProtection $\left(\gamma_{2}\right)$ & $\begin{array}{l}0.002 \\
(0.895)\end{array}$ & $\begin{array}{l}0.028^{\text {****** }} \\
(0.000)\end{array}$ & $\begin{array}{l}-2.304 \\
(0.562)\end{array}$ & $\begin{array}{l}0.422 \\
(0.182)\end{array}$ & $\begin{array}{l}-1.820 \\
(0.636)\end{array}$ \\
\hline CapitalStringency $\left(\gamma_{3}\right)$ & $\begin{array}{l}-0.017 \\
(0.118)\end{array}$ & $\begin{array}{l}-0.010^{*} \\
(0.056)\end{array}$ & $\begin{array}{l}6.395^{* * *} \\
(0.038)\end{array}$ & $\begin{array}{l}0.364^{*} \\
(0.055)\end{array}$ & $\begin{array}{l}6.018^{* * *} \\
(0.041)\end{array}$ \\
\hline OfficialSupervisory $\left(\gamma_{4}\right)$ & $\begin{array}{l}0.005 \\
(0.487)\end{array}$ & $\begin{array}{l}0.011^{* * *} \\
(0.044)\end{array}$ & $\begin{array}{l}7.736^{* *} \\
(0.017)\end{array}$ & $\begin{array}{l}0.103 \\
(0.508)\end{array}$ & $\begin{array}{l}7.606^{* * *} \\
(0.015)\end{array}$ \\
\hline Intercept $\left(\alpha_{0}\right)$ & $\begin{array}{l}2.260^{* * *} \\
(0.000)\end{array}$ & $\begin{array}{l}0.449^{* * *} \\
(0.000)\end{array}$ & $\begin{array}{l}108.264^{*} \\
(0.048)\end{array}$ & $\begin{array}{l}9.156^{* * *} \\
(0.002)\end{array}$ & $\begin{array}{l}98.623^{*} \\
(0.061)\end{array}$ \\
\hline $\begin{array}{l}\text { Number of observations } \\
\text { Number of banks } \\
\text { R-square (overall) }\end{array}$ & $\begin{array}{l}4,476 \\
808 \\
0.392 \\
\end{array}$ & $\begin{array}{l}4,476 \\
808 \\
0.200\end{array}$ & $\begin{array}{l}4,476 \\
808 \\
0.057\end{array}$ & $\begin{array}{l}4,476 \\
808 \\
0.076\end{array}$ & $\begin{array}{l}4,476 \\
808 \\
0.059\end{array}$ \\
\hline $\begin{array}{r}\text { Wald tests: } \\
\begin{aligned} \alpha_{1}+\alpha_{2} \\
\text { P-value } \\
\alpha_{1}+\alpha_{3} \\
\text { P-value }\end{aligned}\end{array}$ & $\begin{array}{l}0.002^{* *} \\
(0.020) \\
-0.002^{* * * *} \\
(0.001)\end{array}$ & $\begin{array}{l}-0.001^{* *} \\
(0.015) \\
0.002^{* * * *} \\
(0.001)\end{array}$ & $\begin{array}{l}-0.463 \\
(0.138) \\
-1.083^{* * *} \\
(0.000)\end{array}$ & $\begin{array}{l}-0.008 \\
(0.698) \\
-0.035^{* * * *} \\
(0.004)\end{array}$ & $\begin{array}{l}-0.456 \\
(0.129) \\
-1.046 \\
(0.000)\end{array}$ \\
\hline
\end{tabular}

Variables definition: ROA=2-year rolling-window mean of the return on average assets; SDROA=2-year rolling-window standard deviation of the return on average assets; ZScore=measure of bank default risk; Z1Score=measure of bank asset risk; Z2Score=measure of leverage risk; ExcessControl=difference between control and cash-flow rights; Crisis=dummy equal to one if the year is 2007 or 2008 , and zero otherwise; PostCrisis=dummy equal to one if the year is 2009 or 2010, and zero otherwise; $\log ($ Assets)=natural logarithm of total assets; Equity=ratio of total equity to total assets; Deposits=ratio of customer deposits to total assets; Loans=ratio of net loans to total assets; NNII=ratio of net non-interest income to net operating income; CostIncomeRatio=cost to income ratio; Listed=dummy equal to one if the bank is publicly listed, and zero otherwise; Rescue=dummy equal to one if the bank was rescued during the 2007-2008 financial crisis, and zero otherwise; Bank-Foundation is a set of dummy variables representing the type of the largest ultimate owner (Widely is the benchmark group); GDPGrowth=real GDP growth rate; RightsProtection=anti-director index of the level of shareholder protection; CapitalStringency=regulatory capital stringency index; OfficialSupervisory=index of official supervisory power. P-values based on robust standard errors are shown in parentheses. ${ }^{* * *},{ }^{* *}$ and ${ }^{*}$ indicate significance respectively at the $1 \%, 5 \%$ and $10 \%$ levels. 
Table A4: Excess control rights, bank profitability and risk: excluding rescued banks (2002-2010, GLS)

$\mathrm{Y}_{\mathrm{it}}=\left(\alpha_{1}+\alpha_{2}\right.$ Crisis $+\alpha_{3}$ PostCrisis $)$ ExcessControl ${ }_{i \mathrm{t}}+\delta^{\prime} \mathrm{TDummy}+\varphi^{\prime} \mathrm{X}+\gamma^{\prime} \mathrm{Z}+\alpha_{0}+\varepsilon_{\mathrm{it}}$

\begin{tabular}{|c|c|c|c|c|c|}
\hline Dependent variable $(\mathrm{Y})$ & ROA & SDROA & ZScore & Z1Score & Z2Score \\
\hline ExcessControl $\left(\alpha_{1}\right)$ & $\begin{array}{l}-0.003^{* * *} \\
(0.005)\end{array}$ & $\begin{array}{l}0.001^{* * *} \\
(0.021)\end{array}$ & $\begin{array}{l}-0.348^{* * * *} \\
(0.000)\end{array}$ & $\begin{array}{l}-0.010^{* * *} \\
(0.037)\end{array}$ & $\begin{array}{l}-0.338^{* * *} \\
(0.000)\end{array}$ \\
\hline Crisis $\times$ ExcessControl $\left(\alpha_{2}\right)$ & $\begin{array}{l}0.005^{* * * *} \\
(0.004)\end{array}$ & $\begin{array}{l}-0.002^{* * * *} \\
(0.000)\end{array}$ & $\begin{array}{l}0.193^{* * *} \\
(0.026)\end{array}$ & $\begin{array}{l}0.009^{* * *} \\
(0.031)\end{array}$ & $\begin{array}{l}0.184^{* *} \\
(0.038)\end{array}$ \\
\hline PostCrisis $\times$ ExcessControl $\left(\alpha_{3}\right)$ & $\begin{array}{l}0.001 \\
(0.473)\end{array}$ & $\begin{array}{l}0.000 \\
(0.940)\end{array}$ & $\begin{array}{l}0.066 \\
(0.435)\end{array}$ & $\begin{array}{l}0.006 \\
(0.408)\end{array}$ & $\begin{array}{l}0.060 \\
(0.440)\end{array}$ \\
\hline Crisis $\left(\delta_{1}\right)$ & $-0.139^{* * *}$ & $0.030^{*}$ & $-6.478^{* *}$ & $-0.815^{* x^{*}}$ & $-5.703^{* *}$ \\
\hline PostCrisis $\left(\delta_{2}\right)$ & $\begin{array}{l}-0.294^{* * *} \\
(0.000)\end{array}$ & $\begin{array}{l}0.046^{* * * *} \\
(0.005)\end{array}$ & $\begin{array}{l}-8.233^{* *} \\
(0.037)\end{array}$ & $\begin{array}{l}-1.017^{* * * *} \\
(0.000)\end{array}$ & $\begin{array}{l}-7.202^{* *} \\
(0.046)\end{array}$ \\
\hline $\log ($ Assets $)\left(\varphi_{1}\right)$ & $\begin{array}{l}-0.100^{* * *} \\
(0.000)\end{array}$ & $\begin{array}{l}-0.060^{* * *} \\
(0.000)\end{array}$ & $\begin{array}{l}-1.739^{*} \\
(0.054)\end{array}$ & $\begin{array}{l}0.160^{* *} \\
(0.013)\end{array}$ & $\begin{array}{l}-1.882^{* *} \\
(0.028)\end{array}$ \\
\hline Equity $\left(\varphi_{2}\right)$ & $\begin{array}{l}0.216^{* * * * *} \\
(0.000)\end{array}$ & $\begin{array}{l}0.065^{* * * *} \\
(0.000)\end{array}$ & $\begin{array}{l}5.102^{* * *} \\
(0.003)\end{array}$ & $\begin{array}{l}0.004 \\
(0.968)\end{array}$ & $\begin{array}{l}5.058^{* * * *} \\
(0.003)\end{array}$ \\
\hline Deposits $\left(\varphi_{3}\right)$ & $\begin{array}{l}0.002^{* * * *} \\
(0.001)\end{array}$ & $\begin{array}{l}-0.000 \\
(0.810)\end{array}$ & $\begin{array}{l}0.119^{*} \\
(0.065)\end{array}$ & $\begin{array}{l}0.019^{* * * *} \\
(0.000)\end{array}$ & $\begin{array}{l}0.103^{*} \\
(0.090)\end{array}$ \\
\hline Loans $\left(\varphi_{4}\right)$ & $\begin{array}{l}0.001 \\
(0.111)\end{array}$ & $\begin{array}{l}-0.002^{* * * *} \\
(0.000)\end{array}$ & $\begin{array}{l}0.302^{* * *} \\
(0.000)\end{array}$ & $\begin{array}{l}0.023^{* * * *} \\
(0.000)\end{array}$ & $\begin{array}{l}0.276^{* * *} \\
(0.000)\end{array}$ \\
\hline $\mathrm{NNII}\left(\varphi_{5}\right)$ & $\begin{array}{l}0.003^{* * * *} \\
(0.000)\end{array}$ & $\begin{array}{l}0.000 \\
(0.317)\end{array}$ & $\begin{array}{l}-0.120^{* * *} \\
(0.004)\end{array}$ & $\begin{array}{l}0.002 \\
(0.617)\end{array}$ & $\begin{array}{l}-0.117^{* * *} \\
(0.003)\end{array}$ \\
\hline CostIncomeRatio $\left(\varphi_{6}\right)$ & $\begin{array}{l}-0.013^{* * *} \\
(0.000)\end{array}$ & $\begin{array}{l}0.001^{* * * *} \\
(0.004)\end{array}$ & $\begin{array}{l}-0.251^{* * * *} \\
(0.000)\end{array}$ & $\begin{array}{l}-0.046^{* * * *} \\
(0.000)\end{array}$ & $\begin{array}{l}-0.208^{* * * *} \\
(0.000)\end{array}$ \\
\hline Listed $\left(\varphi_{7}\right)$ & $\begin{array}{l}0.209^{* * * * *} \\
(0.000)\end{array}$ & $\begin{array}{l}0.048 \\
(0.150)\end{array}$ & $\begin{array}{l}-19.371^{* * * *} \\
(0.000)\end{array}$ & $\begin{array}{l}-0.250 \\
(0.520)\end{array}$ & $\begin{array}{l}-19.123^{* * *} \\
(0.000)\end{array}$ \\
\hline $\operatorname{Bank}\left(\varphi_{8}\right)$ & $\begin{array}{l}0.021 \\
(0.559)\end{array}$ & $\begin{array}{l}0.001 \\
(0.972)\end{array}$ & $\begin{array}{l}-6.625 \\
(0.186)\end{array}$ & $\begin{array}{l}-0.216 \\
(0.540)\end{array}$ & $\begin{array}{l}-6.424 \\
(0.175)\end{array}$ \\
\hline Family $\left(\varphi_{9}\right)$ & $\begin{array}{l}0.099^{* * *} \\
(0.019)\end{array}$ & $\begin{array}{l}0.028 \\
(0.352)\end{array}$ & $\begin{array}{l}-2.983 \\
(0.597)\end{array}$ & $\begin{array}{l}-0.058 \\
(0.887)\end{array}$ & $\begin{array}{l}-2.855 \\
(0.589)\end{array}$ \\
\hline State $\left(\varphi_{10}\right)$ & $\begin{array}{l}0.004 \\
(0.950)\end{array}$ & $\begin{array}{l}0.028 \\
(0.571)\end{array}$ & $\begin{array}{l}-3.554 \\
(0.658)\end{array}$ & $\begin{array}{l}-0.531 \\
(0.328)\end{array}$ & $\begin{array}{l}-3.044 \\
(0.691)\end{array}$ \\
\hline Institutional $\left(\varphi_{11}\right)$ & $\begin{array}{l}0.027 \\
(0.524)\end{array}$ & $\begin{array}{l}-0.026 \\
(0.429)\end{array}$ & $\begin{array}{l}-3.367 \\
(0.493)\end{array}$ & $\begin{array}{l}-0.144 \\
(0.642)\end{array}$ & $\begin{array}{l}-3.199 \\
(0.494)\end{array}$ \\
\hline Industry $\left(\varphi_{12}\right)$ & $\begin{array}{l}0.021 \\
(0.747)\end{array}$ & $\begin{array}{l}0.087 \\
(0.170)\end{array}$ & $\begin{array}{l}0.598 \\
(0.943)\end{array}$ & $\begin{array}{l}0.646 \\
(0.315)\end{array}$ & $\begin{array}{l}-0.087 \\
(0.991)\end{array}$ \\
\hline Foundation $\left(\varphi_{13}\right)$ & $\begin{array}{l}0.028 \\
(0.694)\end{array}$ & $\begin{array}{l}-0.074 \\
(0.122)\end{array}$ & $\begin{array}{l}19.005 \\
(0.101)\end{array}$ & $\begin{array}{l}0.761 \\
(0.231)\end{array}$ & $\begin{array}{l}18.157 \\
(0.101)\end{array}$ \\
\hline GDPGrowth $\left(\gamma_{1}\right)$ & $\begin{array}{l}0.011^{* * *} \\
(0.000)\end{array}$ & $\begin{array}{l}-0.006 \\
(0.005)\end{array}$ & $\begin{array}{l}0.879^{* *} \\
(0.018)\end{array}$ & $\begin{array}{l}0.060^{* *} \\
(0.036)\end{array}$ & $\begin{array}{l}0.826^{* *} \\
(0.018)\end{array}$ \\
\hline RightsProtection $\left(\gamma_{2}\right)$ & $\begin{array}{l}0.040^{* * * *} \\
(0.008)\end{array}$ & $\begin{array}{l}0.033^{\text {**** }} \\
(0.008)\end{array}$ & $\begin{array}{l}-1.705 \\
(0.254)\end{array}$ & $\begin{array}{l}-0.286 \\
(0.112)\end{array}$ & $\begin{array}{l}-1.391 \\
(0.330)\end{array}$ \\
\hline CapitalStringency $\left(\gamma_{3}\right)$ & $\begin{array}{l}-0.018 \\
(0.114)\end{array}$ & $\begin{array}{l}-0.018^{* * *} \\
(0.045)\end{array}$ & $\begin{array}{l}2.805^{* * *} \\
(0.016)\end{array}$ & $\begin{array}{l}0.232^{* * *} \\
(0.011)\end{array}$ & $\begin{array}{l}2.558^{* * *} \\
(0.021)\end{array}$ \\
\hline OfficialSupervisory $\left(\gamma_{4}\right)$ & $\begin{array}{l}0.005 \\
(0.508)\end{array}$ & $\begin{array}{l}0.017^{* * * *} \\
(0.009)\end{array}$ & $\begin{array}{l}2.750^{* * *} \\
(0.021)\end{array}$ & $\begin{array}{l}0.042 \\
(0.488)\end{array}$ & $\begin{array}{l}2.697^{* * *} \\
(0.019)\end{array}$ \\
\hline Intercept $\left(\alpha_{0}\right)$ & $\begin{array}{l}1.991^{* * *} \\
(0.000)\end{array}$ & $\begin{array}{l}0.665^{* *} \\
(0.000)\end{array}$ & $\begin{array}{l}43.5766^{* *} \\
(0.017)\end{array}$ & $\begin{array}{l}3.364^{* * *} \\
(0.006)\end{array}$ & $\begin{array}{l}40.135^{* *} \\
(0.021)\end{array}$ \\
\hline $\begin{array}{l}\text { Number of observations } \\
\text { Number of banks } \\
\text { R-square (overall) }\end{array}$ & $\begin{array}{l}4.230 \\
754 \\
0.385\end{array}$ & $\begin{array}{l}4.230 \\
754 \\
0.199\end{array}$ & $\begin{array}{l}4.230 \\
754 \\
0.069\end{array}$ & $\begin{array}{l}4.230 \\
754 \\
0.123\end{array}$ & $\begin{array}{l}4.230 \\
754 \\
0.069\end{array}$ \\
\hline $\begin{array}{l}\text { Wald tests: } \\
\qquad \begin{aligned} \alpha_{1}+\alpha_{2} \\
\text { P-value } \\
\\
\alpha_{1}+\alpha_{3} \\
\text { P-value }\end{aligned}\end{array}$ & $\begin{array}{l}0.002^{* *} \\
(0.033) \\
-0.002^{* *} \\
(0.010)\end{array}$ & $\begin{array}{l}-0.001^{* *} \\
(0.012) \\
0.001^{* * *} \\
(0.045)\end{array}$ & $\begin{array}{l}-0.155 \\
(0.147) \\
-0.282^{* * *} \\
(0.000)\end{array}$ & $\begin{array}{l}-0.001 \\
(0.789) \\
-0.004 \\
(0.801)\end{array}$ & $\begin{array}{l}-0.154 \\
(0.160) \\
-0.278^{* * *} \\
(0.000)\end{array}$ \\
\hline
\end{tabular}

Variables definition: ROA=3-year rolling-window mean of the return on average assets; SDROA=3-year rolling-window standard deviation of the return on average assets; ZScore=measure of bank default risk; Z1Score=measure of bank asset risk; Z2Score=measure of leverage risk; ExcessControl=difference between control and cash-flow rights; Crisis=dummy equal to one if the year is 2007 or 2008 , and zero otherwise; PostCrisis=dummy equal to one if the year is 2009 or 2010, and zero otherwise; $\log ($ Assets $)=$ natural logarithm of total assets; Equity=ratio of total equity to total assets; Deposits=ratio of customer deposits to total assets; Loans=ratio of net loans to total assets; NNII=ratio of net non-interest income to net operating income; CostIncomeRatio=cost to income ratio; Listed=dummy equal to one if the bank is publicly listed, and zero otherwise; Bank-Foundation is a set of dummy variables representing the type of the largest ultimate owner (Widely is the benchmark group); GDPGrowth=real GDP growth rate; RightsProtection=anti-director index of the level of shareholder protection; CapitalStringency=regulatory capital stringency index; OfficialSupervisory=index of official supervisory power. Pvalues based on robust standard errors are shown in parentheses. ${ }^{* * *}{ }^{* * *}$ and ${ }^{*}$ indicate significance respectively at the $1 \%, 5 \%$ and $10 \%$ levels. 
Table A5: Excess control rights, bank profitability and risk (2002-2010, GLS): control threshold of $20 \%$ $\mathrm{Y}_{\mathrm{it}}=\left(\alpha_{1}+\alpha_{2}\right.$ Crisis $+\alpha_{3}$ PostCrisis $)$ ExcessControl ${ }_{i \mathrm{it}}+\delta^{\prime}$ TDummy $+\varphi^{\prime} \mathrm{X}+\gamma^{\prime} \mathrm{Z}+\alpha_{0}+\varepsilon_{\mathrm{it}}$

\begin{tabular}{|c|c|c|c|c|c|}
\hline Dependent variable $(\mathrm{Y})$ & ROA & SDROA & ZScore & Z1Score & Z2Score \\
\hline ExcessControl $\left(\alpha_{1}\right)$ & $\begin{array}{l}-0.003^{* * * *} \\
(0.004)\end{array}$ & $\begin{array}{l}0.001^{* * *} \\
(0.016)\end{array}$ & $\begin{array}{l}-0.332^{* * *} \\
(0.001)\end{array}$ & $\begin{array}{l}-0.012^{* * *} \\
(0.047)\end{array}$ & $\begin{array}{l}-0.320^{* * * *} \\
(0.004)\end{array}$ \\
\hline Crisis $\times$ ExcessControl $\left(\alpha_{2}\right)$ & $\begin{array}{l}0.005^{* * * *} \\
(0.002)\end{array}$ & $\begin{array}{l}-0.002^{* * * *} \\
(0.000)\end{array}$ & $\begin{array}{l}0.182 \\
(0.555)\end{array}$ & $\begin{array}{l}0.008^{* * *} \\
(0.037)\end{array}$ & $\begin{array}{l}0.174 \\
(0.649)\end{array}$ \\
\hline PostCrisis $\times$ ExcessControl $\left(\alpha_{3}\right)$ & $\begin{array}{l}0.001 \\
(0.420)\end{array}$ & $\begin{array}{l}0.000 \\
(0.972)\end{array}$ & $\begin{array}{l}0.070 \\
(0.393)\end{array}$ & $\begin{array}{l}0.007 \\
(0.305)\end{array}$ & $\begin{array}{l}0.064 \\
(0.405)\end{array}$ \\
\hline Crisis $\left(\delta_{1}\right)$ & $\begin{array}{l}-0.131^{* * * *} \\
(0.000)\end{array}$ & $\begin{array}{l}0.025^{*} \\
(0.097)\end{array}$ & $\begin{array}{l}-6.364^{*} \\
(0.024)\end{array}$ & $\begin{array}{l}-0.833^{\text {*** }} \\
(0.001)\end{array}$ & $\begin{array}{l}-5.568^{* *} \\
(0.034)\end{array}$ \\
\hline PostCrisis $\left(\delta_{2}\right)$ & $\begin{array}{l}-0.283^{* * *} \\
(0.000)\end{array}$ & $\begin{array}{l}0.044^{* * * *} \\
(0.004)\end{array}$ & $\begin{array}{l}-7.145^{* * *} \\
(0.023)\end{array}$ & $\begin{array}{l}-1.032^{* * * *} \\
(0.000)\end{array}$ & $\begin{array}{l}-6.101^{* *} \\
(0.026)\end{array}$ \\
\hline $\log$ (Assets) $\left(\varphi_{1}\right)$ & $\begin{array}{l}-0.101^{* * *} \\
(0.000)\end{array}$ & $\begin{array}{l}-0.056^{* * *} \\
(0.000)\end{array}$ & $\begin{array}{l}-2.036^{* *} \\
(0.013)\end{array}$ & $\begin{array}{l}0.147^{* *} \\
(0.013)\end{array}$ & $\begin{array}{l}-2.166^{* * *} \\
(0.005)\end{array}$ \\
\hline Equity $\left(\varphi_{2}\right)$ & $\begin{array}{l}0.214^{* * *} \\
(0.000)\end{array}$ & $\begin{array}{l}0.066^{* * * *} \\
(0.000)\end{array}$ & $\begin{array}{l}4.864^{* * * *} \\
(0.004)\end{array}$ & $\begin{array}{l}-0.013 \\
(0.886)\end{array}$ & $\begin{array}{l}4.832^{* * * *} \\
(0.003)\end{array}$ \\
\hline Deposits $\left(\varphi_{3}\right)$ & $\begin{array}{l}0.002^{* * * *} \\
(0.000)\end{array}$ & $\begin{array}{l}0.000 \\
(0.925)\end{array}$ & $\begin{array}{l}0.101 \\
(0.101)\end{array}$ & $\begin{array}{l}0.017^{* * * *} \\
(0.000)\end{array}$ & $\begin{array}{l}0.087 \\
(0.135)\end{array}$ \\
\hline Loans $\left(\varphi_{4}\right)$ & $\begin{array}{l}0.001 \\
(0.139)\end{array}$ & $\begin{array}{l}-0.002^{* * *} \\
(0.001)\end{array}$ & $\begin{array}{l}0.291^{* * * *} \\
(0.000)\end{array}$ & $\begin{array}{l}0.022^{* * * *} \\
(0.000)\end{array}$ & $\begin{array}{l}0.267^{* * * *} \\
(0.000)\end{array}$ \\
\hline $\mathrm{NNII}\left(\varphi_{5}\right)$ & $\begin{array}{l}0.003^{* * * *} \\
(0.000)\end{array}$ & $\begin{array}{l}0.000 \\
(0.242)\end{array}$ & $\begin{array}{l}-0.101^{* *} \\
(0.011)\end{array}$ & $\begin{array}{l}0.004 \\
(0.231)\end{array}$ & $\begin{array}{l}-0.101^{* * * *} \\
(0.007)\end{array}$ \\
\hline CostIncomeRatio $\left(\varphi_{6}\right)$ & $\begin{array}{l}-0.013^{* * * *} \\
(0.000)\end{array}$ & $\begin{array}{l}0.001^{\text {****** }} \\
(0.004)\end{array}$ & $\begin{array}{l}-0.251^{* * * *} \\
(0.000)\end{array}$ & $\begin{array}{l}-0.046^{* * * *} \\
(0.000)\end{array}$ & $\begin{array}{l}-0.208^{* * * *} \\
(0.000)\end{array}$ \\
\hline Listed $\left(\varphi_{7}\right)$ & $\begin{array}{l}0.195^{* * *} \\
(0.000)\end{array}$ & $\begin{array}{l}0.048 \\
(0.116)\end{array}$ & $\begin{array}{l}-18.856^{* * *} \\
(0.000)\end{array}$ & $\begin{array}{l}-0.342 \\
(0.351)\end{array}$ & $\begin{array}{l}-18.513^{* * *} \\
(0.000)\end{array}$ \\
\hline Rescue $\left(\varphi_{8}\right)$ & $\begin{array}{l}0.031 \\
(0.570)\end{array}$ & $\begin{array}{l}-0.010 \\
(0.809)\end{array}$ & $\begin{array}{l}-3.825 \\
(0.465)\end{array}$ & $\begin{array}{l}-0.456 \\
(0.442)\end{array}$ & $\begin{array}{l}-3.326 \\
(0.479)\end{array}$ \\
\hline $\operatorname{Bank}\left(\varphi_{9}\right)$ & $\begin{array}{l}0.017 \\
(0.612)\end{array}$ & $\begin{array}{l}0.002 \\
(0.953)\end{array}$ & $\begin{array}{l}-5.775 \\
(0.222)\end{array}$ & $\begin{array}{l}-0.175 \\
(0.603)\end{array}$ & $\begin{array}{l}-5.614 \\
(0.210)\end{array}$ \\
\hline Family $\left(\varphi_{10}\right)$ & $\begin{array}{l}0.096^{* * *} \\
(0.018)\end{array}$ & $\begin{array}{l}0.032 \\
(0.260)\end{array}$ & $\begin{array}{l}-3.440 \\
(0.519)\end{array}$ & $\begin{array}{l}-0.116 \\
(0.766)\end{array}$ & $\begin{array}{l}-3.242 \\
(0.516)\end{array}$ \\
\hline State $\left(\varphi_{11}\right)$ & $\begin{array}{l}0.008 \\
(0.909)\end{array}$ & $\begin{array}{l}0.045 \\
(0.315)\end{array}$ & $\begin{array}{l}-5.474 \\
(0.459)\end{array}$ & $\begin{array}{l}-0.723 \\
(0.154)\end{array}$ & $\begin{array}{l}-4.785 \\
(0.496)\end{array}$ \\
\hline Institutional $\left(\varphi_{12}\right)$ & $\begin{array}{l}0.021 \\
(0.610)\end{array}$ & $\begin{array}{l}-0.026 \\
(0.414)\end{array}$ & $\begin{array}{l}-2.474 \\
(0.607)\end{array}$ & $\begin{array}{l}-0.124 \\
(0.687)\end{array}$ & $\begin{array}{l}-2.329 \\
(0.611)\end{array}$ \\
\hline Industry $\left(\varphi_{13}\right)$ & $\begin{array}{l}0.021 \\
(0.752)\end{array}$ & $\begin{array}{l}0.086 \\
(0.166)\end{array}$ & $\begin{array}{l}0.878 \\
(0.915)\end{array}$ & $\begin{array}{l}0.647 \\
(0.307)\end{array}$ & $\begin{array}{l}0.196 \\
(0.980)\end{array}$ \\
\hline Foundation $\left(\varphi_{14}\right)$ & $\begin{array}{l}0.028 \\
(0.679)\end{array}$ & $\begin{array}{l}-0.073 \\
(0.111)\end{array}$ & $\begin{array}{l}18.484^{*} \\
(0.100)\end{array}$ & $\begin{array}{l}0.646 \\
(0.292)\end{array}$ & $\begin{array}{l}17.750^{*} \\
(0.098)\end{array}$ \\
\hline GDPGrowth $\left(\gamma_{1}\right)$ & $\begin{array}{l}0.013^{* 3 *} \\
(0.000)\end{array}$ & $\begin{array}{l}-0.005^{* * *} \\
(0.009)\end{array}$ & $\begin{array}{l}0.956 \\
(0.006)\end{array}$ & $\begin{array}{l}0.076^{*} \\
(0.007)\end{array}$ & $\begin{array}{l}0.886^{* \cdots *} \\
(0.007)\end{array}$ \\
\hline RightsProtection $\left(\gamma_{2}\right)$ & $\begin{array}{l}0.043^{\text {**** }} \\
(0.003)\end{array}$ & $\begin{array}{l}0.031^{* * * *} \\
(0.008)\end{array}$ & $\begin{array}{l}-1.447 \\
(0.316)\end{array}$ & $\begin{array}{l}0.234 \\
(0.135)\end{array}$ & $\begin{array}{l}-1.185 \\
(0.390)\end{array}$ \\
\hline CapitalStringency $\left(\gamma_{3}\right)$ & $\begin{array}{l}-0.019^{*} \\
(0.071)\end{array}$ & $\begin{array}{l}-0.018^{* * *} \\
(0.031)\end{array}$ & $\begin{array}{l}3.141^{* * * *} \\
(0.005)\end{array}$ & $\begin{array}{l}0.234^{* * * *} \\
(0.007)\end{array}$ & $\begin{array}{l}2.892^{* * * *} \\
(0.006)\end{array}$ \\
\hline OfficialSupervisory $\left(\gamma_{4}\right)$ & $\begin{array}{l}0.005 \\
(0.535)\end{array}$ & $\begin{array}{l}0.019^{* * * *} \\
(0.004)\end{array}$ & $\begin{array}{l}2.528^{* * *} \\
(0.030)\end{array}$ & $\begin{array}{l}0.032 \\
(0.587)\end{array}$ & $\begin{array}{l}2.486^{* * *} \\
(0.027)\end{array}$ \\
\hline Intercept $\left(\alpha_{0}\right)$ & $\begin{array}{l}2.002^{* * *} \\
(0.000)\end{array}$ & $\begin{array}{l}0.606^{* * *} \\
(0.000)\end{array}$ & $\begin{array}{l}44.271^{* *} \\
(0.014)\end{array}$ & $\begin{array}{l}3.405^{* * *} \\
(0.005)\end{array}$ & $\begin{array}{l}40.802^{* *} \\
(0.017)\end{array}$ \\
\hline $\begin{array}{l}\text { Number of observations } \\
\text { Number of banks } \\
\text { R-square (overall) }\end{array}$ & $\begin{array}{l}4,451 \\
788 \\
0.386\end{array}$ & $\begin{array}{l}4,451 \\
788 \\
0.199\end{array}$ & $\begin{array}{l}4,451 \\
788 \\
0.067\end{array}$ & $\begin{array}{l}4,451 \\
788 \\
0.121\end{array}$ & $\begin{array}{l}4,451 \\
788 \\
0.068\end{array}$ \\
\hline $\begin{aligned} \text { Wald tests : } & \alpha_{1}+\alpha_{2} \\
& \text { P-value } \\
& \alpha_{1}+\alpha_{3} \\
& \text { P-value }\end{aligned}$ & $\begin{array}{l}0.002^{* *} \\
(0.039) \\
-0.002^{* *} \\
(0.019)\end{array}$ & $\begin{array}{l}-0.001^{* * *} \\
(0.007) \\
0.001^{* *} \\
(0.026)\end{array}$ & $\begin{array}{l}-0.150 \\
(0.167) \\
-0.263^{* * *} \\
(0.005)\end{array}$ & $\begin{array}{l}-0.004 \\
(0.316) \\
-0.005 \\
(0.286) \\
\end{array}$ & $\begin{array}{l}-0.146 \\
(0.184) \\
-0.256^{* * * *} \\
(0.006)\end{array}$ \\
\hline
\end{tabular}

Variables definition: ROA=3-year rolling-window mean of the return on average assets; SDROA=3-year rolling-window standard deviation of the return on average assets; ZScore=measure of bank default risk; Z1Score=measure of bank asset risk; Z2Score=measure of leverage risk; ExcessControl=difference between control and cash-flow rights; Crisis=dummy equal to one if the year is 2007 or 2008 , and zero otherwise; PostCrisis=dummy equal to one if the year is 2009 or 2010, and zero otherwise; $\log ($ Assets)=natural logarithm of total assets; Equity=ratio of total equity to total assets; Deposits=ratio of customer deposits to total assets; Loans=ratio of net loans to total assets; NNII=ratio of net non-interest income to net operating income; CostIncomeRatio=cost to income ratio; Listed=dummy equal to one if the bank is publicly listed, and zero otherwise; Rescue=dummy equal to one if the bank was rescued during the 2007-2008 financial crisis, and zero otherwise; Bank-Foundation is a set of dummy variables representing the type of the largest ultimate owner (Widely is the benchmark group); GDPGrowth=real GDP growth rate; RightsProtection=anti-director index of the level of shareholder protection; CapitalStringency=regulatory capital stringency index; OfficialSupervisory=index of official supervisory power. P-values based on robust standard errors are shown in parentheses. ${ }_{* * *}^{* * *}$ and ${ }^{*}$ indicate significance respectively at the $1 \%, 5 \%$ and $10 \%$ levels. 
Table A6: Excess control rights, bank profitability and risk (GLS): regressions on subsamples

$\mathrm{Y}_{\mathrm{it}}=\alpha_{1}$ ExcessControl $_{\mathrm{it}}+\varphi^{\prime} \mathrm{X}+\gamma^{\prime} \mathrm{Z}+\delta^{\prime}$ Year $+\alpha_{0}+\varepsilon_{\mathrm{it}}$

\begin{tabular}{|c|c|c|c|c|c|c|c|c|c|c|c|c|c|c|c|}
\hline \multirow[b]{2}{*}{ Dependent variable $(\mathrm{Y})$} & \multicolumn{5}{|c|}{ Pre-crisis period (2002-2006) } & \multicolumn{5}{|c|}{ Crisis period $(2007-2008)$} & \multicolumn{5}{|c|}{ Post-crisis period (2009-2010) } \\
\hline & ROA & SDROA & ZScore & Z1Score & Z2Score & ROA & SDROA & ZScore & Z1Score & Z2Score & ROA & SDROA & ZScore & Z1Score & Z2Score \\
\hline ExcessControl $\left(\alpha_{1}\right)$ & $\begin{array}{l}-0.004^{* * *} \\
(0.000)\end{array}$ & $\begin{array}{l}0.001^{* *} \\
(0.023)\end{array}$ & $\begin{array}{l}-0.282^{* * *} \\
(0.000)\end{array}$ & $\begin{array}{l}-0.008^{*} \\
(0.061)\end{array}$ & $\begin{array}{l}-0.271^{* * *} \\
(0.000)\end{array}$ & $\begin{array}{l}0.001^{* *} \\
(0.049)\end{array}$ & $\begin{array}{l}-0.001^{*} \\
(0.056)\end{array}$ & $\begin{array}{l}-0.087 \\
(0.362)\end{array}$ & $\begin{array}{l}0.012 \\
(0.134)\end{array}$ & $\begin{array}{l}-0.100 \\
(0.265)\end{array}$ & $\begin{array}{l}-0.003^{* * *} \\
(0.000)\end{array}$ & $\begin{array}{l}0.001^{* *} \\
(0.046)\end{array}$ & $\begin{array}{l}-0.297^{* * *} \\
(0.000)\end{array}$ & $\begin{array}{l}-0.002 \\
(0.758)\end{array}$ & $\begin{array}{l}-0.295^{* * *} \\
(0.000)\end{array}$ \\
\hline $\log$ (Assets) $\left(\varphi_{1}\right)$ & $\begin{array}{l}-0.111^{* * *} \\
(0.000)\end{array}$ & $\begin{array}{l}-0.052^{* * * x} \\
(0.000)\end{array}$ & $\begin{array}{l}-2.456^{* * * *} \\
(0.007)\end{array}$ & $\begin{array}{l}0.139^{* * *} \\
(0.041)\end{array}$ & $\begin{array}{l}-2.607^{* * * *} \\
(0.003)\end{array}$ & $\begin{array}{c}-0.084^{* 3 *} \\
(0.000)\end{array}$ & $\begin{array}{c}-0.062^{* * *} \\
(0.000)\end{array}$ & $\begin{array}{l}-1.089 \\
(0.318)\end{array}$ & $\begin{array}{c}0.379^{* \cdots *} \\
(0.000)\end{array}$ & $\begin{array}{l}-1.468 \\
(0.152)\end{array}$ & $\begin{array}{c}-0.059^{* \ldots *} \\
(0.000)\end{array}$ & $\begin{array}{c}-0.059^{* * 3 *} \\
(0.000)\end{array}$ & $\begin{array}{c}-4.145^{* * *} \\
(0.000)\end{array}$ & $\begin{array}{l}-0.101 \\
(0.245)\end{array}$ & $\begin{array}{c}-4.042^{* * x} \\
(0.000)\end{array}$ \\
\hline Equity $\left(\varphi_{2}\right)$ & $\begin{array}{l}0.198^{* * *} \\
(0.000)\end{array}$ & $\begin{array}{l}0.097^{* * * *} \\
(0.000)\end{array}$ & $\begin{array}{l}1.160 \\
(0.572)\end{array}$ & $\begin{array}{l}-0.156 \\
(0.197)\end{array}$ & $\begin{array}{l}1.264 \\
(0.519)\end{array}$ & $\begin{array}{c}0.287^{* * *} \\
(0.000)\end{array}$ & $\begin{array}{l}0.109^{* * *} \\
(0.000)\end{array}$ & $\begin{array}{c}12.039^{* * * *} \\
(0.000)\end{array}$ & $\begin{array}{c}0.128 \\
(0.425)\end{array}$ & $\begin{array}{c}11.909^{* * * *} \\
(0.000)\end{array}$ & $\begin{array}{l}0.164^{* * * *} \\
(0.000)\end{array}$ & $\begin{array}{c}0.107^{* * * *} \\
(0.000)\end{array}$ & $\begin{array}{c}4.024 \\
(0.193)\end{array}$ & $\begin{array}{l}-0.248 \\
(0.103)\end{array}$ & $\begin{array}{c}4.289 \\
(0.153)\end{array}$ \\
\hline Deposits $\left(\varphi_{3}\right)$ & $\begin{array}{l}0.003^{* * *} \\
(0.000)\end{array}$ & $\begin{array}{l}-0.000 \\
(0.744)\end{array}$ & $\begin{array}{l}0.013 \\
(0.878)\end{array}$ & $\begin{array}{l}0.013^{* *} \\
(0.031)\end{array}$ & $\begin{array}{l}0.003 \\
(0.969)\end{array}$ & $\begin{array}{l}0.002^{* * *} \\
(0.029)\end{array}$ & $\begin{array}{l}-0.001 \\
(0.320)\end{array}$ & $\begin{array}{l}0.179^{* *} \\
(0.050)\end{array}$ & $\begin{array}{c}0.029^{* * * *} \\
(0.000)\end{array}$ & $\begin{array}{l}0.149^{*} \\
(0.084)\end{array}$ & $\begin{array}{l}0.003^{* * * *} \\
(0.000)\end{array}$ & $\begin{array}{l}-0.001 \\
(0.288)\end{array}$ & $\begin{array}{c}0.137 \\
(0.202)\end{array}$ & $\begin{array}{l}0.030^{* * * * *} \\
(0.000)\end{array}$ & $\begin{array}{c}0.107 \\
(0.289)\end{array}$ \\
\hline Loans $\left(\varphi_{4}\right)$ & $\begin{array}{l}0.001 \\
(0.379)\end{array}$ & $\begin{array}{l}-0.001^{*} \\
(0.077)\end{array}$ & $\begin{array}{l}0.225^{* * *} \\
(0.008)\end{array}$ & $\begin{array}{l}0.021^{* * * *} \\
(0.000)\end{array}$ & $\begin{array}{l}0.204^{* *} \\
(0.011)\end{array}$ & $\begin{array}{c}0.000 \\
(0.641)\end{array}$ & $\begin{array}{c}-0.001^{* * * * *} \\
(0.003)\end{array}$ & $\begin{array}{l}0.407^{* * * * *} \\
(0.000)\end{array}$ & $\begin{array}{l}0.030^{* * * * *} \\
(0.000)\end{array}$ & $\begin{array}{l}0.378^{* * * *} \\
(0.000)\end{array}$ & $\begin{array}{c}-0.002^{* * * *} \\
(0.001)\end{array}$ & $\begin{array}{l}-0.001^{*} \\
(0.092)\end{array}$ & $\begin{array}{l}0.408^{* * * * * *} \\
(0.000)\end{array}$ & $\begin{array}{l}0.016^{* *} \\
(0.015)\end{array}$ & $\begin{array}{l}0.392^{* * * *} \\
(0.000)\end{array}$ \\
\hline $\mathrm{NNII}\left(\varphi_{5}\right)$ & $\begin{array}{l}0.004^{* * *} \\
(0.000)\end{array}$ & $\begin{array}{l}0.001^{* *} \\
(0.039)\end{array}$ & $\begin{array}{l}-0.148^{* * * *} \\
(0.009)\end{array}$ & $\begin{array}{l}0.005 \\
(0.257)\end{array}$ & $\begin{array}{l}-0.149^{* * * *} \\
(0.005)\end{array}$ & $\begin{array}{l}0.003^{* * * *} \\
(0.002)\end{array}$ & $\begin{array}{c}0.000 \\
(0.656)\end{array}$ & $\begin{array}{c}-0.282^{* * * *} \\
(0.001)\end{array}$ & $\begin{array}{c}0.007 \\
(0.286)\end{array}$ & $\begin{array}{c}-0.285^{* * *} \\
(0.000)\end{array}$ & $\begin{array}{l}0.002^{* * *} \\
(0.034)\end{array}$ & $\begin{array}{l}0.002^{* * * * *} \\
(0.010)\end{array}$ & $\begin{array}{c}-0.281^{* * * *} \\
(0.000)\end{array}$ & $\begin{array}{l}-0.002 \\
(0.745)\end{array}$ & $\begin{array}{c}-0.278^{* * * *} \\
(0.000)\end{array}$ \\
\hline CostIncomeRatio $\left(\varphi_{6}\right)$ & $\begin{array}{l}-0.012^{* * * *} \\
(0.000)\end{array}$ & $\begin{array}{l}0.001 \\
(0.167)\end{array}$ & $\begin{array}{l}-0.171^{* * * *} \\
(0.005)\end{array}$ & $\begin{array}{l}-0.036^{* * *} \\
(0.000)\end{array}$ & $\begin{array}{l}-0.139^{* *} \\
(0.013)\end{array}$ & $\begin{array}{c}-0.011^{* * * *} \\
(0.000)\end{array}$ & $\begin{array}{l}0.001^{* * *} \\
(0.023)\end{array}$ & $\begin{array}{c}-0.343^{* * *} \\
(0.000)\end{array}$ & $\begin{array}{c}-0.065^{* * *} \\
(0.000)\end{array}$ & $\begin{array}{c}-0.280^{* * *} \\
(0.000)\end{array}$ & $\begin{array}{c}-0.013^{* * * *} \\
(0.000)\end{array}$ & $\begin{array}{l}0.002^{* * * *} \\
(0.002)\end{array}$ & $\begin{array}{c}-0.306^{* * *} \\
(0.001)\end{array}$ & $\begin{array}{c}-0.067^{* * * *} \\
(0.000)\end{array}$ & $\begin{array}{c}-0.240^{* * *} \\
(0.008)\end{array}$ \\
\hline Listed $\left(\varphi_{7}\right)$ & $\begin{array}{l}0.243^{* * * *} \\
(0.000)\end{array}$ & $\begin{array}{l}0.023 \\
(0.476)\end{array}$ & $\begin{array}{l}-14.731^{* * * *} \\
(0.003)\end{array}$ & $\begin{array}{l}-0.195 \\
(0.619)\end{array}$ & $\begin{array}{l}-14.479^{* * *} \\
(0.002)\end{array}$ & $\begin{array}{l}0.135^{* *} \\
(0.012)\end{array}$ & $\begin{array}{l}0.058^{*} \\
(0.096)\end{array}$ & $\begin{array}{c}-19.504^{* * * *} \\
(0.001)\end{array}$ & $\begin{array}{c}0.524 \\
(0.349)\end{array}$ & $\begin{array}{c}-20.016^{* * * *} \\
(0.000)\end{array}$ & $\begin{array}{l}-0.027 \\
(0.589)\end{array}$ & $\begin{array}{l}0.063^{*} \\
(0.069)\end{array}$ & $\begin{array}{c}-28.199^{* * * *} \\
(0.000)\end{array}$ & $\begin{array}{l}-1.231^{* * *} \\
(0.012)\end{array}$ & $\begin{array}{c}-26.980^{* * * *} \\
(0.000)\end{array}$ \\
\hline Rescue $\left(\varphi_{8}\right)$ & - & - & - & - & - & $\begin{array}{r}-0.029 \\
-(0.666) \\
\end{array}$ & $\begin{array}{c}0.091 \\
(0.206) \\
\end{array}$ & $\begin{array}{r}-11.541 \\
-(0.190)\end{array}$ & $\begin{array}{r}-0.612 \\
(0.529) \\
\end{array}$ & $\begin{array}{l}-10.920 \\
(0.176)\end{array}$ & $\begin{array}{c}0.029 \\
0.749) \\
\end{array}$ & $\begin{array}{c}(0.082) \\
0.08217) \\
-(0.217\end{array}$ & $\begin{array}{r}-8.354 \\
(0.359) \\
\end{array}$ & $\begin{array}{r}-0.756 \\
-(0.271) \\
\end{array}$ & $\begin{array}{r}-7.604 \\
(0.374) \\
\end{array}$ \\
\hline GDPGrowth $\left(\gamma_{1}\right)$ & $\begin{array}{l}0.024^{* * *} \\
(0.002)\end{array}$ & $\begin{array}{l}-0.014^{* *} \\
(0.011)\end{array}$ & $\begin{array}{l}1.929^{* * * *} \\
(0.001)\end{array}$ & $\begin{array}{l}0.317^{* * * *} \\
(0.000)\end{array}$ & $\begin{array}{l}1.613^{* * \ldots} \\
(0.003)\end{array}$ & $\begin{array}{l}0.078^{* *} \\
(0.000)\end{array}$ & $\begin{array}{l}-0.000 \\
(0.904)\end{array}$ & $\begin{array}{l}1.856^{* *} \\
(0.032)\end{array}$ & $\begin{array}{l}0.339^{* *} \\
(0.000)\end{array}$ & $\begin{array}{l}1.509^{*} \\
(0.058)\end{array}$ & $\begin{array}{l}0.005^{*} \\
(0.079)\end{array}$ & $\begin{array}{l}-0.007^{* * * *} \\
(0.002)\end{array}$ & $\begin{array}{l}0.575 \\
(0.190)\end{array}$ & $\begin{array}{l}-0.007 \\
(0.824)\end{array}$ & $\begin{array}{l}0.581 \\
(0.159)\end{array}$ \\
\hline RightsProtection $\left(\gamma_{2}\right)$ & $\begin{array}{l}0.078^{* * * *} \\
(0.000)\end{array}$ & $\begin{array}{l}0.024^{*} \\
(0.067)\end{array}$ & $\begin{array}{l}-1.945 \\
(0.266)\end{array}$ & $\begin{array}{l}-0.248 \\
(0.108)\end{array}$ & $\begin{array}{l}-1.571 \\
(0.345)\end{array}$ & $\begin{array}{l}0.055^{* * *} \\
(0.014)\end{array}$ & $\begin{array}{c}0.004 \\
(0.748)\end{array}$ & $\begin{array}{l}1.485 \\
(0.503)\end{array}$ & $\begin{array}{l}0.354^{* *} \\
(0.037)\end{array}$ & $\begin{array}{l}1.127 \\
(0.593)\end{array}$ & $\begin{array}{l}0.043 \\
(0.200)\end{array}$ & $\begin{array}{l}0.027^{*} \\
(0.067)\end{array}$ & $\begin{array}{l}-4.384^{* * *} \\
(0.025)\end{array}$ & $\begin{array}{l}-0.233 \\
(0.001)\end{array}$ & $\begin{array}{l}-4.151^{* *} \\
(0.036)\end{array}$ \\
\hline CapitalStringency $\left(\gamma_{3}\right)$ & $\begin{array}{l}-0.037^{* * *} \\
(0.003)\end{array}$ & $\begin{array}{l}-0.016^{*} \\
(0.089)\end{array}$ & $\begin{array}{l}2.979^{* * *} \\
(0.019)\end{array}$ & $\begin{array}{l}0.207^{* * *} \\
(0.031)\end{array}$ & $\begin{array}{l}2.768^{* *} \\
(0.021)\end{array}$ & $\begin{array}{l}-0.022 \\
(0.105)\end{array}$ & $\begin{array}{l}-0.006 \\
(0.408)\end{array}$ & $\begin{array}{c}1.764 \\
(0.229)\end{array}$ & $\begin{array}{l}0.005 \\
(0.972)\end{array}$ & $\begin{array}{l}1.755 \\
(0.202)\end{array}$ & $\begin{array}{l}0.010 \\
(0.470)\end{array}$ & $\begin{array}{l}-0.014 \\
(0.138)\end{array}$ & $\begin{array}{l}2.289 \\
(0.135)\end{array}$ & $\begin{array}{l}0.310^{* *} \\
(0.016)\end{array}$ & $\begin{array}{l}1.971 \\
(0.169)\end{array}$ \\
\hline OfficialSupervisory $\left(\gamma_{4}\right)$ & $\begin{array}{l}0.009 \\
(0.373)\end{array}$ & $\begin{array}{l}0.017^{* *} \\
(0.011)\end{array}$ & $\begin{array}{l}2.653^{* *} \\
(0.036)\end{array}$ & $\begin{array}{l}0.021 \\
(0.760)\end{array}$ & $\begin{array}{l}2.634^{* * *} \\
(0.030)\end{array}$ & $\begin{array}{c}-0.002 \\
(0.822)\end{array}$ & $\begin{array}{c}0.005 \\
(0.490) \\
\end{array}$ & $\begin{array}{r}2.149 \\
(0.109) \\
\end{array}$ & $\begin{array}{c}0.007 \\
(0.942)\end{array}$ & $\begin{array}{l}2.132^{*} \\
(0.095)\end{array}$ & $\begin{array}{l}-0.017^{*} \\
(0.089)\end{array}$ & $\begin{array}{l}0.019^{* *} \\
(0.034)\end{array}$ & $\begin{array}{l}2.495^{\prime \prime} \\
(0.086)\end{array}$ & $\begin{array}{l}-0.077 \\
(0.360) \\
\end{array}$ & $\begin{array}{l}2.568^{*} \\
(0.064)\end{array}$ \\
\hline Intercept $\left(\alpha_{0}\right)$ & $\begin{array}{l}2.003^{* * * *} \\
(0.000)\end{array}$ & $\begin{array}{l}0.568^{* * * * *} \\
(0.000)\end{array}$ & $\begin{array}{l}55.161^{* * *} \\
(0.009)\end{array}$ & $\begin{array}{l}3.320^{* * *} \\
(0.022)\end{array}$ & $\begin{array}{l}51.747^{* * *} \\
(0.009)\end{array}$ & $\begin{array}{l}1.694^{* *} \\
(0.000)\end{array}$ & $\begin{array}{c}0.847^{* * *} \\
(0.000)\end{array}$ & $\begin{array}{r}42.787^{*} \\
-(0.091)\end{array}$ & $\begin{array}{c}1.563 \\
(0.447)\end{array}$ & $\begin{array}{l}41.395^{*} \\
(0.082)\end{array}$ & $\begin{array}{l}1.981^{* * *} \\
(0.000)\end{array}$ & $\begin{array}{l}0.506^{* * *} \\
(0.002)\end{array}$ & $\begin{array}{c}90.751^{* * *} \\
(0.001)\end{array}$ & $\begin{array}{l}7.465^{* * * *} \\
(0.000)\end{array}$ & $\begin{array}{c}83.320^{\circ} \\
(0.002)\end{array}$ \\
\hline Ownership type & Yes & Yes & Yes & Yes & Yes & Yes & Yes & Yes & Yes & Yes & Yes & Yes & Yes & Yes & Yes \\
\hline Year dummies (Year) & Yes & Yes & Yes & Yes & Yes & Yes & Yes & Yes & Yes & Yes & Yes & Yes & Yes & Yes & Yes \\
\hline Number of observations & $\begin{array}{l}2,396 \\
708\end{array}$ & $\begin{array}{l}2,396 \\
708\end{array}$ & $\begin{array}{l}2,396 \\
708\end{array}$ & $\begin{array}{l}2,396 \\
708\end{array}$ & $\begin{array}{l}2,396 \\
708\end{array}$ & $\begin{array}{l}1,051 \\
620\end{array}$ & $\begin{array}{l}1,051 \\
620\end{array}$ & $\begin{array}{l}1,051 \\
620\end{array}$ & $\begin{array}{l}1,051 \\
620\end{array}$ & $\begin{array}{l}1,051 \\
620\end{array}$ & $\begin{array}{l}1,004 \\
593\end{array}$ & $\begin{array}{l}1,004 \\
593\end{array}$ & $\begin{array}{l}1,004 \\
593\end{array}$ & $\begin{array}{l}1,004 \\
593\end{array}$ & $\begin{array}{l}1,004 \\
593\end{array}$ \\
\hline R-square (overall) & 0.424 & 0.210 & 0.062 & 0.090 & 0.065 & 0.408 & 0.314 & 0.121 & 0.174 & 0.124 & 0.313 & 0.227 & 0.142 & 0.181 & 0.143 \\
\hline
\end{tabular}

Variables definition: ROA=3-year rolling-window mean of the return on average assets; SDROA=3-year rolling-window standard deviation of the return on average assets; ZScore=measure of bank default risk; Z1Score=measure of bank asset risk; Z2Score=measure of leverage risk; ExcessControl=difference between control and cash-flow rights; Log(Assets)=natural logarithm of total assets; Equity=ratio of total equity to total assets; Deposits=ratio of customer deposits to total assets; Loans=ratio of net loans to total assets; NNII=ratio of net non-interest income to net operating income; CostIncomeRatio=cost to income ratio; Listed=dummy equal to one if the bank is publicly listed, and zero otherwise; Rescue=dummy equal to one if the bank was rescued during the 2007-2008 financial crisis, and zero otherwise; GDPGrowth=real GDP growth rate; RightsProtection=anti-director index of the level of shareholder protection; CapitalStringency=regulatory capital stringency index; OfficialSupervisory=index of official supervisory power; Ownership type=set of dummy variables representing the type of the largest ultimate owner (Widely is the benchmark group). P-values based on robust standard errors are shown in parentheses. ${ }^{* * *},{ }^{* *}$ and ${ }^{*}$ indicate significance respectively at the $1 \%, 5 \%$ and $10 \%$ levels. 